UNIVERSIDADE DE SÃO PAULO

FACULDADE DE FILOSOFIA, LETRAS E CIÊNCIAS HUMANAS

DEPARTAMENTO DE LETRAS MODERNAS

PROGRAMA DE PÓS-GRADUAÇÃO EM LITERATURA ITALIANA

\title{
AS TRADUÇÕES BRASILEIRAS DE I FIORETTI DI SAN FRANCESCO: A LEITURA DA OBRA NO BRASIL
}

Débora de Souza Balancin

Dissertação apresentada ao Programa de Pós-Graduação em Literatura Italiana do Departamento de Letras Modernas da Faculdade de Filosofia, Letras e Ciências Humanas da Universidade de São Paulo, para a obtenção do título de Mestre em Letras.

Orientador: Prof. Dr. Pedro Garcez Ghirardi

São Paulo

2008 
A теи раі

"Na vida aquece ser pequeno..."

(Fernando Pessoa) 


\section{Agradecimentos}

Gostaria de dizer obrigada a algumas pessoas que estiveram comigo durante estes 3 anos e meio de trabalho:

A meu orientador, Pedro, por tudo. Sem palavras. Admiração.

A minha mãe, pela acolhida em sua casa nos últimos meses.

A meus irmãos Daniela e Lucas, pela paciência nos momentos de estresse, pelo carinho e apoio de sempre.

A Lucila, amiga-irmã, pelo ombro nos momentos difíceis e pelo vinho nos alegres.

A Monika, pela rosa verde.

A Ana Cristina, compreensão sem limites.

A minha avó, pelas “aulas” de italiano.

Aos professores John Milton e Noé Silva, pelas observações atentas e ajuda imprescindível em minha banca de qualificação. 
This document was created with Win2PDF available at http://www.win2pdf.com.

The unregistered version of Win2PDF is for evaluation or non-commercial use only. This page will not be added after purchasing Win2PDF. 


\section{Resumo:}

A presente dissertação constitui-se da análise das traduções brasileiras do século XX da obra italiana I Fioretti di San Francesco. Através da análise das escolhas lexicais dos tradutores, e tomando a tradução como um ato lingüístico metonímico, procura-se apresentar as diferentes leituras de I Fioretti disponíveis ao público brasileiro: uma mais rebuscada e clericalizada, porém mais atenta ao original como obra de valor literário; outra mais simples e mais acessível, apesar de menos atenta ao caráter literário do original.

\section{Abstract:}

The present dissertation is an analysis of the 20th century Brazilian translations of I Fioretti di San Francesco. Through the analysis of the translators' lexical choices, and taking translation as a metonimic linguistic act, it intends to present the different readings of I Fioretti available to the Brazilian readers: one more far-fetched and clericalized, but more attentive to the original as a book with literary value; another more simple and accessible though less sensitive to the literary aspect of the original.

\section{Riassunto :}

Il presente lavoro comprende l'analisi delle traduzioni brasiliane del ventesimo secolo dell'opera italiana I Fioretti di San Francesco. Tramite l'analisi delle scelte lessicali fatte dai traduttori, e prendendo la traduzione come un atto linguistico metonimico, si presenteranno le differenti letture de I Fioretti messe a disposizione del pubblico brasiliano: una più ricercata e clericalizzata, però più attenta all'originale come opera di valore letterario; un'altra più semplice e accessibile anche se non così attenta al carattere letterario dell'originale. 
This document was created with Win2PDF available at http://www.win2pdf.com.

The unregistered version of Win2PDF is for evaluation or non-commercial use only. This page will not be added after purchasing Win2PDF. 
Sumário

APRESENTAÇÃO..............................................................................................................01

INTRODUÇÃO.............................................................................................................03

1. DE FRANCISCO DE ASSIS AOS FIORETTI.................................................

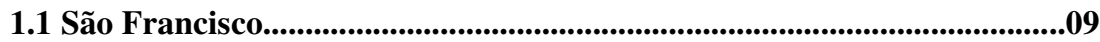

1.2 A Questão Franciscana................................................................................11

1.3 I Fioretti di San Francesco............................................................................13

2. SUBSÍDIOS DE I FIORETTI NO BRASIL..................................................18

2.1 As traduções de I Fioretti do século XX..............................................................18

2.1.1 A tradução de Adelino Capistrano....................................................18

2.1.2 A tradução de Durval de Morais....................................................20

2.2 Convites à leitura: as introduções................................................................22

\section{COMENTÁRIOS ÀS TRADUÇÕES BRASILEIRAS DE I FIORETTI DI SAN}

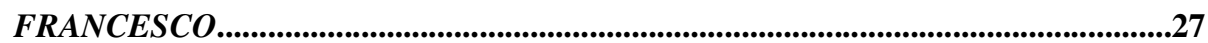

3.1 Rubrica, saudação final, paragrafação.......................................................27

3.2 A parte pelo todo: as escolhas lexicais dos tradutores..............................32

3.3 "Fidelidade" ma non troppo.............................................................................81

3.4 Dar com esta mão e tirar com a outra... ...................................................99

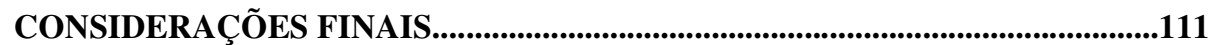

REFERÊNCIAS BIBLIOGRÁFICAS....................................................................114 
This document was created with Win2PDF available at http://www.win2pdf.com.

The unregistered version of Win2PDF is for evaluation or non-commercial use only. This page will not be added after purchasing Win2PDF. 
Apresentação

\author{
“...perché non si può trattenere tutto \\ ed è bene che il fiume perda parte della propria acqua \\ se vuole mantenersi integro nel suo corso, \\ se vuole avere un corso riconoscibile."
}

A presente dissertação nasce de um súbito “innamoramento” pela Literatura Italiana da Idade Média e de um amor antigo pela tradução. Aqui, a união de ambos em uma análise de $I$ Fioretti di San Francesco.

O projeto iniciou-se com a recolha das traduções brasileiras da obra. Delimitei a análise às traduções impressas e publicadas no Brasil e no século XX. Importante ressaltar que analiso as traduções brasileiras e não de língua portuguesa; sendo assim, não considero no presente trabalho as edições de Portugal.

A publicação em português de I Fioretti di San Francesco no Brasil não chegou a se difundir muito, restringindo-se a edições atualmente já esgotadas - encontradas apenas em sebos e bibliotecas - das décadas de 1930 a 1970. Aqui lido com as traduções de Durval de Morais (publicada pela editora Vozes) e de Adelino Capistrano (publicada pelas editoras Atena e Ediouro), das quais voltarei a falar.

A partir dos trabalhos tradutórios acima citados, realizo um cotejo com a obra original para que se possa esboçar, de algum modo, o que foi passado ao leitor brasileiro. Dentre os vários aspectos que poderiam ser investigados, optei por expor diferenças de aspectos lexicais entre as traduções e a obra original - exame de opções lexicais dos tradutores -, a existência ou não de omissões, acréscimos e erros denotativos. Tais elementos - nesta pesquisa - são postos sob olhar da tradução como metonímia.

Coloco em evidência que adotei aqui uma análise da acepção contemporânea dos vocábulos e não tanto de seus significados no século XIV; isto é, presumo uma leitura do original como se poderia fazer hoje, por leitor não especialista da obra. O eventual prosseguimento da pesquisa buscará priorizar os aspectos que ficam por desenvolver.

1 ECO, Umberto. Il Nome della Rosa. Bompiani: Milano, 1980, p. 186. 
Antes, porém, de iniciar o cotejo, apresento algumas reflexões sobre a Tradução e a Linguagem, além de considerações sobre a obra original, cujas traduções são aqui examinadas.

Mesmo sem pretender o esgotamento da análise, espero trazer uma contribuição para os estudos de Tradução e de Literatura Italiana. 


\title{
Introdução
}

\author{
«Olá, guardador de rebanhos, \\ Aí à beira da estrada, \\ Que te diz o vento que passa?» \\ «Que é vento, e que passa, \\ E que já passou antes, \\ E que passará depois. \\ E a ti o que te diz?»
}

«Muita coisa mais do que isso,

Fala-me de muitas outras coisas.

De memórias e de saudades

E de coisas que nunca foram.»

\section{«Nunca ouviste passar o vento. \\ $O$ vento só fala do vento. \\ o que lhe ouviste foi mentira, \\ E a mentira está em ti.» ${ }^{2}$}

Aqui exponho a teoria de tradução com a qual mais identifico o meu trabalho e sobre a qual basearei as minhas considerações.

Para compreender o início de minhas reflexões, junto com Steiner (1992), voltemos a alguns dos principais aspectos da Teoria da Linguagem.

2 CAEIRO, Alberto. Ficções do Interlúdio. Poema X. IN: PESSOA, Fernando. Obra Poética. Rio de Janeiro: Nova Aguilar, 1998, p. 213. 


\title{
"A roupa larga"
}

A língua pode ser vista como uma roupa larga que vestimos na "realidade". Conseguimos vestir esta tal "realidade", mas as roupas são largas e sobram. Não há uma caída perfeita. Não há uma caída única. Cada pessoa veste a "realidade" à sua maneira.

Isto é, duas pessoas falam a mesma língua - por exemplo, o português brasileiro da cidade de São Paulo. Porém, quando uma delas diz ou escreve uma palavra qualquer - por exemplo "janela" -, cada uma delas pensará em algo comum, mas este mesmo pensamento ganhará conotações, cores, tamanhos, formas diferentes. A primeira, talvez, pensará em uma janela azul clarinha e de metal, já que esta é a janela do seu quarto; a outra, talvez, pense em uma janela de madeira grande, por ser esta a janela da casa em que passou a infância.

Apesar de termos um objeto, uma realidade comum, quando entramos em contato com a "roupa" que vestimos nesta "realidade" - ou seja, a língua -, percebemos que há, sim, uma distância entre a palavra e o objeto que cada um tem em mente. Afinal, a palavra "janela" é azul e de metal ou é grande e de madeira? É, ao mesmo tempo, as duas e nenhuma.

\begin{abstract}
"No two speakers mean exactly the same thing when they use the same terms; or if they do, there is no conceivable way of demonstrating perfect homology. No complete, verifiable act of communication is, therefore, possible. All discourse is fundamentally monadic or idiolectic. » (STEINER, 1992, p. 263).
\end{abstract}

Assim, se duas pessoas que falam, teoricamente, a mesma língua, se deparam com este problema de comunicação, devemos ter em mente que o problema ganha graus outros. Duas pessoas que moram na cidade de São Paulo e que utilizam a língua portuguesa falada no Brasil a utilizam de maneira diferente; o uso que se faz na cidade de São Paulo desta mesma língua é diferente do uso que se faz em São José do Rio Preto - interior do estado de São Paulo; esta mesma língua usada por paulistas será diferente do uso dos brasileiros que moram no Estado da Bahia ou do Rio Grande do Sul; o português brasileiro é diferente do português de Portugal; e, lógico, ganha graus extremos quando comparamos duas línguas diversas. 


\title{
A mentira
}

O ser humano cria mentiras. E as mentiras são criadas para sobreviver.

A língua nos permite falar de coisas desconhecidas e fazer planos para o futuro. Permite que finjamos ser quem não somos, que criemos outros mundos. Ao permitir que falemos de coisas nunca antes experimentadas, nunca antes vistas, a língua nos proporciona a possibilidade de. Assim, o ser humano não se restringe somente àquilo que viveu e que vive hoje, mas pode sair do presente, de sua condição falível e limitada. A língua permite ilimitação.

\begin{abstract}
«Man's sensibility endures and transcends the brevity, the haphazard ravages, the psysiological programming of individual life because the semantically coded responses of the mind are constantly broader, freer, more inventive than the demands and stimulus of the material fact." (STEINER, 1992, p. 238).
\end{abstract}

Quando falamos de coisas nunca antes vividas, estamos "mentindo". Quando falamos do futuro - já que este não é de nosso domínio -, estamos "mentindo". Quando usamos o condicional, quando as crianças brincam de "faz de conta", quando contamos e criamos estórias, estamos "mentindo". A mentira aqui não ganha o sentido pejorativo que a maioria das vezes lhe é dado. A mentira aqui diz respeito à elasticidade, ou melhor, ao espaço deixado pela língua humana, que é a "roupa larga" da "realidade".

O ser humano não sobrevive se for capaz de falar, imaginar e contar apenas aquilo que acontece no presente e no passado. Imagine-se uma língua que possibilitasse o pensamento apenas de hoje - não há amanhã. Não há amanhã simplesmente porque não existe o conceito, idéia e expressão de futuro em sua língua. Não posso imaginar mundos outros simplesmente porque minha língua não possibilita isso. Sobreviveríamos apenas com a idéia do presente? Sem poder imaginar que um dia vai passar a dor que sentimos hoje? Que a sociedade pode melhorar?

"Language is the main instrument of man's refusal to accept the world as it is. " (STEINER, 1992, p. 228).

\footnotetext{
« Counter-factuals and conditionals, argues Bloch, make up a grammar of constant renewal. They force us to proceed afresh in the morning, to leave failed history behind. Otherwise our posture would be static and we would choke on disappointed dreams. » (STEINER, 1992, p. 227).
} 
«Each different tongue offers its own denial determinism. 'The world', it says, 'can be other'. Ambiguity, polysemy, opaqueness, the violation of grammatical and logical sequences, reciprocal incomprehensions, the capacity to lie - these are not pathologies of language but the roots of its genius. Without them the individual and the species would have withered. » (STEINER, 1992, p. 246).

Assim, a língua não pode ser e não é a "cobertura" perfeita da "realidade" - a língua a recria de acordo com quem a utiliza.

"Or to put it simply: there is a direct, crucial correlation between the 'un-truthful' and fictive genius of human speech on the one hand and the great multiplicity of languages on the other." (STEINER, 1992, p. 243).

\section{A comunicação}

Sendo assim, nunca entenderemos realmente o que diz o outro; a comunicação é baseada em ambigüidades, experiências de "realidade" diferentes, mentiras, obscuridades. A comunicação, então, é impossível, porém, é estabelecida a todo momento.

A comunicação existe porque, apesar de pensarmos em "janelas" diferentes, pensamos em uma "janela". A linha que toca a "realidade" existe.

“"Thus not even 'basic notions", central points in a human sphere of experience, stand outside the area of arbitrary segmentation and arrangement and subsequent conventionalization; and the extent to which semantic boundaries as determined by linguistic form and linguistic usage coincide with absolute boundaries in the world around us is negligible." (STEINER, 1992, pp. 252-253).

Porém, quando lidamos com línguas diferentes, este "toque", este "fio" que permite a comunicação inexiste. E para que a comunicação se estabeleça, é preciso que haja este "fio" ou um dos dois fala a língua estrangeira ou há um tradutor.

Se a comunicação entre pessoas de mesma língua não se dá de maneira plena, quando se trata de pessoas de línguas diversas, a comunicação simplesmente não é estabelecida. Tudo o que eu disser é novo. O ser humano não consegue lidar com este todo novo, procuramos sempre adaptar aos nossos conhecimentos prévios este novo. Mas quando o novo é COMPLETAMENTE novo, ficando impossível estabelecer relações com o que já experienciamos, a comunicação simplesmente não se dá. 


\section{A tradução}

Todo ato lingüístico é uma tradução. Quando falamos, traduzimos pensamentos em língua. Procuramos transformar toda aquela carga de ambigüidades, vivências em algo passível de compreensão.

\footnotetext{
"In translation the dialectic of unison and of plurality is dramatically at work. In one sense, each act of translation is an endeavour to abolish multiplicity and to bring different world-pictures back into perfect congruence. In another sense, it is an attempt to reinvent the shape of meaning, to find and justify an alternate statement. » (STEINER, 1992, p. 246).
}

Quando falo, traduzo; quando ouço, interpreto. Quando escrevo, traduzo; quando leio, interpreto. Na tradução, transformamos a "roupa larga" em "medida justa"; na interpretação, transformamos a "medida justa" em "roupa larga".

Eu penso no objeto janela azul e de metal e digo - janela. Parte do meu pensamento se perde, ou melhor, apenas parte do meu pensamento é comunicado. Ou seja, todo ato lingüístico é metonímico.

A tradução interlingüística é um ato lingüístico e, portanto, pode ser considerada metonímica ${ }^{3}$ Se tomo a palavra "janela" como conceito de tudo aquilo que está por trás quando a pronuncio ou escrevo, estou tomando esta "parte" pelo todo.

A tradução interlingüística literária trabalha com os mesmos conceitos até aqui demonstrados, mas todos em seu grau extremo. Se a comunicação entre dois indivíduos que falam a mesma língua não é plena, na tradução interlingüística, lidamos com línguas diferentes, que comportam vivências coletivas diferentes, espaços físicos diferentes.

Um texto literário lida com a língua em seu grau máximo de conotação, de "mentira". Se a "roupa" que veste a "realidade" é larga, em literatura a "roupa" é extremamente larga.

Quando, então, leio um texto - e todo tradutor é um leitor do texto que traduz - leio-o de acordo com a minha vivência pessoal e com a minha vivência e experiência das línguas da qual e para a qual traduzo. A tradução é a uma leitura possível da obra.

3 Metonímia: Segundo Maria Tymoczko - "figure of speech in which an attribute or an aspect of an entity substitutes for the entity or in which a part substitutes for the whole" (TYMOCZKO, 1999, p. 42). 
Deste modo, lido aqui com duas possíveis leituras da obra I Fioretti di San Francesco.

E pretendo analisar quais foram as leituras passadas, então, para o leitor brasileiro - quais partes deste todo o Brasil leu. 


\section{De Francisco de Assis aos Fioretti}

“Ma perch'io non proceda troppo chiuso,

Francesco e Povertà per questi amanti

Prendi oramai nel mio parlar diffuso."

\subsection{São Francisco}

Nascido em Assis em 1181-1182, filho de um comerciante de sucesso - Pietro Bernardone -, Francisco levou uma vida coerente com sua condição social até, mais ou menos, seus vinte anos.

Não optou por seguir a carreira de seu pai, mas sim pelas armas - que lhe davam prestígio junto ao meio que freqüentava.

Em 1202, partiu para a guerra contra Perúsia e foi feito prisioneiro por um ano. De volta, em 1203, ficou doente por mais um ano. Ajudou seu pai por algum tempo e, mais tarde - 1205 -, saiu para uma nova empreitada bélica na região da Apúlia - serviu aos exércitos papais contra as tropas imperiais. No caminho, em Espoleto, "encontra um pobre cavaleiro em andrajos e lhe dá sua capa” (LE GOFF, 2001, p. 64). Tommaso da Celano - seu primeiro e principal biógrafo - também cita o episódio da peregrinação a Roma, durante a qual experimenta a vida nômade e a mendicância. Ao voltar a Assis, afastou-se lentamente de sua vida habitual. Passou a meditar em uma gruta afastada.

Diante de tal mudança, seu pai, que havia investido em sua vida social para uma futura ascensão da família, tem-no por enlouquecido. Francisco, apesar de cristão, não possuía nenhuma específica cultura eclesial ou das Escrituras e passa a pregar o Evangelho e a Santa Povertà.

Foi trancafiado por seu pai. Quando solto, despe-se e renuncia a todos os bens diante do bispo, do povo de Assis e de seu pai.

"Va e ripara la mia Chiesa che sta rovinando" - teriam sido estas as palavras, ditas por Deus a Francisco, que o fizeram reconstruir a igrejinha de São Damião e a chamada

4 ALIGHIERI, Dante. A Divina Comédia. Paraíso, Canto XI. São Paulo: Editora 34, p. 81. 
Porciúncula na região de Santa Maria dos Anjos com as próprias mãos e a ajuda dos que por ali passavam.

Logo uma pequena família se formou em torno de Francisco. Atraídos por sua serena pobreza, por sua segurança de sacrifício, juntaram-se os primeiros discípulos: Bernardo da Quintavalle, Pietro Cattani, Silvestro, Egídio, Elia, Leone. Era uma família simples, formada sem um plano pré-estabelecido, ligada ao Pobrezinho, no exercício da renúncia e da oração.

Aos poucos, sua renúncia e seus companheiros aumentavam. Saíam para pregar o Evangelho e, uma vez ao ano, reuniam-se nos encontros que ficaram conhecidos como Capítulos. Em 1209, em uma peregrinação a Roma, receberam a aprovação oral de Inocêncio III.

Em 1212, após uma pregação em São Rufino, Clara - Santa Clara -, pertencente a uma nobre família de Assis, resolve seguir os passos do Pobrezinho. Aqui se iniciaria uma grande amizade. Sem a intenção de formação de uma ordem feminina, Francisco recebe Clara como um de seus discípulos, deixando-a sob a guarda das monjas beneditinas.

O campo de evangelização limitava-se ainda à Itália, já que as tentativas de Francisco e de seus discípulos de ir ao Oriente, ao Marrocos, fracassaram por várias vezes. O plano de iniciar uma sistemática campanha missionária além-Itália foi promovido no Capítulo de 1217 - os irmãos foram enviados à França, Alemanha, Hungria, Espanha; o próprio Francisco dirigiu-se à França. Tal empreitada missionária não acabará em grande sucesso.

Persistia a vontade de pregar aos muçulmanos no Oriente. Por várias vezes interrompidas as viagens, em 1220, finalmente, Francisco consegue chegar a Damieta para 'libertar' cinco de seus discípulos que estavam sob o poder do emir. Foi recebido pelo sultão al-Malik al-Kamil, do qual obteve um salvo-conduto para visitar a Palestina. Sua viagem foi, mais uma vez, interrompida; desta vez não por motivos climáticos ou de saúde, mas por problemas dentro da ordem. Recebe a notícia de que várias normas haviam sido decididas, em sua ausência, durante um Capítulo.

Francisco, então, volta à Itália. Passa a autoridade da ordem a Pietro Cattani - 29 de setembro de 1220 - e concentra-se na redação de uma Regra para unir e direcionar seus seguidores e, mais tarde, ser aprovada pela Santa Sé. Porém, tal Regra (1221) - constituída de trechos do Evangelho - não foi muito bem recebida por todos; o espírito de sacrifício tinha para Francisco tornado normal o heroísmo de uma vida cotidianamente abandonada à Providência e à renúncia a tudo aquilo que não fosse de extrema necessidade; mas tal ideal não podia ser alcançado por muitos. Deste modo, foi obrigado a escrever novo texto; também 
este não agrada muito a frate Elia - ministro geral da Ordem a partir de março de 1221, após a morte de Pietro Cattani.

Surge, assim, uma espécie de oposição enquanto Francisco estava recolhido. Porém, a Regra escrita pelo Pobrezinho é reconhecida por Honório III com uma Bula em 29 de novembro de 1223 .

Francisco, já doente, distanciou-se da Ordem e passou a viver em total sacrifício e inicia o que será comparado à Paixão de Cristo. Em 1224, sobre o Monte Alverne, surgem os estigmas - em seus pés e mãos a marca do Crucificado. Durante tais sofrimentos, já de volta à Úmbria, sob os cuidados de Irmã Clara, Francisco compõe seus escritos em plena serenidade; dentre eles, o famoso Cantico di Frate Sole ou Cantico delle Creature (1224). Tal texto nos faz recordar sua íntima relação com a natureza: a pregação aos pássaros, aos peixes; a conversão do lobo de Gubbio, entre outros eventos que podemos admirar em I Fioretti; assim como o seu louvor a tudo por Deus criado - incluindo "la sorella morte".

Morre na Porciúncula, em 3 de outubro de 1226.

\subsection{A Questão Franciscana}

Sabe-se que é difícil a compreensão do franciscanismo; não só pelo problema das fontes, mas também pelo fato de a experiência intensa de um indivíduo - Francisco -, estreitamente ligada às condições religiosas e sociais de seu tempo, ser fixada em uma regra canonizada para servir como norma de vida através dos séculos.

Justamente por estar ligado à participação dos que o seguiam, e não apenas à vida ascética e contemplativa de um indivíduo, é que o programa religioso de Francisco de Assis ganha visões diferentes.

$\mathrm{O}$ fato de a pregação de Francisco ter dado origem a uma ordem regular enquadrada nas diretivas da organização eclesiástica induziu alguns a ver o movimento franciscano em estreita relação com a vida oficial da Igreja em seu tempo; outros, pelo contrário, ressaltaram o fato de esse movimento se criar e florescer fora do âmbito do clero e o figuraram como um movimento leigo. Na realidade, a disseminação primeira do movimento franciscano ocorre graças a uma corrente de espírito público, que não extrai sua origem nem de poderes civis, nem de poderes eclesiásticos, mas unicamente da atividade de seu fundador. 
Movimento, portanto, na inspiração e nos objetivos, religioso. Mas como programa religioso fortemente sentido, englobou necessariamente todos os aspectos da vida. Não poderia, assim, não ter ecos de caráter social e político. Ecos muito vastos, se considerarmos que a pregação de Francisco percebia e resolvia certas profundas exigências das classes que sofriam, pela situação política e social do tempo.

Contudo, sua correspondência às necessidades sociais da época não poderia explicar sozinha a influência do ideal franciscano se não se levar em consideração outro elemento. Também outros movimentos (catari, valdesi, umiliati) apresentavam-se como uma tentativa de purificação da sociedade através da pregação e da vivência da pobreza evangélica.

Tais movimentos, porém, eram animados por uma oposição à Igreja de Roma, tida como fonte do mal; já Francisco sempre professou à Igreja, aos Pontífices, aos clérigos, sacerdotes e teólogos respeito e submissão.

O ambiente em que viviam os primeiros seguidores do santo era muito heterogêneo: leigos e clérigos, homens cultos e incultos, ascetas e homens de ação - o que, fatalmente, levava cada um a ver e interpretar a seu modo o ideal de São Francisco. A Cúria, então, tenta frear o movimento e o coloca, pouco a pouco, sob seu controle direto, induzindo São Francisco a abandonar a direção efetiva do movimento.

Francisco impõe alguma resistência à tentativa de uniformização de seu movimento aos tipos tradicionais das ordens já existentes; só após duas tentativas não aprovadas conseguiu escrever uma Regra que atendesse às exigências da Igreja.

De outro lado, seria difícil negar a ligação, no século XIII, entre o movimento franciscano e a propaganda joaquimita (derivada de Joaquim da Fiore5). Há alguns pontos em comum entre o joaquimismo e o franciscanismo.

Um deles é o fato de Joaquim denominar os monges pertencentes à chamada Idade do Espírito com o vocábulo minores. Tal vocábulo também foi usado por Francisco para designar os membros de sua Ordem. Contudo, é oportuno lembrar que minores era um termo que também definia as classes menos nobres de Assis.

Outro ponto em comum: a idéia da conversão pacífica dos infiéis opondo-se à mentalidade guerreira das cruzadas.

\footnotetext{
5 Joaquim da Fiore (1132 - 1202) foi abade cisterciense e filósofo místico, defensor do milenarismo e do advento da Idade do Espírito Santo - Idade esta (precedida pelas Idades do Pai e do Filho) em que o amor universal e a igualdade entre todos os cristãos seriam alcançados, pois os cristãos finalmente compreenderiam e aceitariam o Evangelho de Cristo, sendo assim desnecessárias as intituições disciplinadoras da fé.
} 
Mas esta relação é dada principalmente pelo "reviver" do joaquimismo pelos chamados spirituali franciscanos que, depois da morte de Francisco, enrijeceram sua oposição às correntes oficiais da Ordem (conventuali).

Temos, então, que o programa religioso de Francisco vai ao encontro das mais íntimas exigências religiosas e sociais do momento em que se originou. Assim, não é de se espantar ou de se maravilhar que a Ordem Franciscana tenha extraído do ideal do Santo o que bastasse para constituir uma norma perene de vida que transcendesse as circunstâncias de um determinado momento histórico e que garantisse a vitalidade deste ideal.

\section{Fioretti di San Francesco}

A obra I Fioretti faz parte do contexto literário do Trecento italiano (século XIV); foi redigida por volta de 1370-1390 - data incerta e discutida ainda pelos principais estudiosos. Se no Duecento (século XIII) - no que diz respeito à literatura devota e militante - temos grandes nomes e obras franciscanas como o próprio Francisco e seus escritos (Cantico delle Creature entre outros), Iacopone da Todi, Angela da Foligno -, o Trecento, apesar de apresentar uma predominância dominicana, traz escritos de "heréticos franciscanos" (Storia de Fra Michele Minorita), reescrituras e volgarizzamenti, isto é, traduções adaptadas de textos latinos. A operação de vulgarização, nem casual nem esporádica durante o século em questão, compreende a passagem de textos escritos em latim para o vulgar - no caso, o italiano.

“... non si tratta di "traduzione" degli Actus, bensì di "volgarizzamento", e il volgarizzatore non tanto manipola la fonte, fa opera di grezzo dosaggio, quanto sceglie, seleziona, ricrea, redige in fondo, un'opera diversa dall'archetipo, con una sua fisionomia e una sua autonomia." (TUSCANO, 1976)

Tal operação tornava a obra mais próxima do público. É dentro destas vulgarizações, e no clima das polêmicas dos spirituali (cf. 2.2), que surge a obra I Fioretti di San Francesco.

"La diffusione singolare di volgarizzamenti di opere latine non di rado larghissimamente presenti da decenni o da secoli all'interno delle scuole vescovili o conventuali, come pure la produzione "originale" in volgare, corrispondono 
appunto a questa esigenza di penetrazione all'interno di una società rispetto a cui i modi "ordinari" di comunicazione (il magistero ecclesiastico, la predicazione stessa) sono percepiti oramai come inadequati o insufficienti..." (BALDASSARI, IN: MALATO, 2001, Vol. II, pp. 211-212).

“...testo di purissima lingua toscana, immersi tanto nel clima delle polemiche degli Spirituali da conservare nel dettato volgare tutta l'arcaicità della scrittura duecentesca..." (PETROCCHI apud TUSCANO, 1976, p. 369).

A narrativa de I Fioretti surgiu a partir de Actus Beati Francisci et sociorum eius. Este último - texto em latim - está conservado, em particular, nos manuscritos: Lat. th. d. 23, membr., séc. XV in., mm. 254 X 178 da Biblioteca Bodleiana de Oxford e Magliarebechiano n.II. XI., 20, sec. XV in., membr., mm. 110 X 80 da Biblioteca Nazionale Centrale di Firenze (PETROCCHI, 1957). Os Actus foram escritos nos últimos vinte anos do Duecento por Ugolino da Monte Santa Maria.

\footnotetext{
"Anche in questo caso Giorgio Petrocchi ha potuto per la verità mostrare che non siamo in presenza - come del resto già si sospettava - di un'opera originale, bensì di un volgarizzamento, stavolta però di alta qualità, di un anteriore scritto latino, gli Actus Beati Francisci et sociorum eius, testo esso tardo e attribuito a fra Ugolino da Monte Santa Maria." (MALATO, 2001, Vol. II, p. 284).
}

A obra faz parte de uma ampla tradição manuscrita e, normalmente, vem acompanhada de apêndices - Vita di frate Ginepro, Vita e detti del beato Egidio e Considerazioni sulle Stimmate - seguindo a coletânea original. A autoria de I Fioretti é atribuída a um franciscano toscano; temos, assim, uma controvérsia a respeito da identidade de seu autor. É importante sublinhar que a autoria não é de Francisco de Assis.

É importante ressaltar também que em I Fioretti não temos simplesmente uma tradução do texto latino, mas uma vulgarização, o que explica certa suavização das alusões doutrinárias do texto latino.

Há, em I Fioretti, cinqüenta e três narrativas que ilustram episódios da vida do santo de Assis, de seus primeiros companheiros (os primeiros trinta e oito fioretti), da Ordem Franciscana e de alguns irmãos spirituali da Ordem, da região italiana das Marcas (os últimos treze fioretti); os fioretti XXXIX e XL são dedicados a Santo Antônio de Pádua . Contam um 
período de mais ou menos cem anos - da conversão de Bernardo Quintavalle, primeiro discípulo de Francisco (1209) aos acontecimentos da vida de Giovanni della Vernia (12591322), que entrou para a Ordem em 1272. Originalmente, o texto possui cinqüenta e dois capítulos, mas as edições mais recentes do século XV já trazem o primeiro capítulo dividido em dois. Aqui devo esclarecer que a obra I Fioretti não possui edição crítica:

\footnotetext{
"Manca tuttavia un'edizione critica: le numerose stampe moderne seguono l'ed. Casella (Firenze, Sansoni, 1926), condotta su due mss. fiorentini, Fi BR 1670 e BNC Pal.144 - il più antico dei codici datati, finito di copiare, presumibilmente per uso privato, da un Amaretto il 17 luglio 1396 -, o quella di B. Bughetti (Firenze, Salani, 1925), che attinge a un numero maggiore di codici." (GUALDO \& PALERMO, IN: MALATO, Vol. X, pp. 370-371).
}

Sendo assim, encontraremos diferenças - ainda que pequenas - entre as várias edições do original. A presente dissertação, portanto, considera duas edições:

- I Fioretti di San Francesco - Le considerazioni sulle Stimmate. Introdução e notas de Pier Massimo Forni. Milano: Garzanti, 2003. $2^{\mathrm{a}}$ edição. (texto extraído da edição feita por Giorgio Petrocchi em Francesco d'Assisi. Gli scritti e la leggenda)

- I Fioretti di San Francesco. Introdução de Francesco Grisi. Milano: Tascabili Economici Newton, 1993. $1^{\text {a }}$ edição.

Em suas narrativas, I Fioretti expõem as polêmicas da Ordem Franciscana - vida ativa e contemplativa (cf. Capítulo XVI); franciscanos e dominicanos (cf. Capítulo XVIII); as relações com Luís IX da França (cf. Capítulo XXXIV); a excomunhão de frate Elia (cf. Capítulo XXXVIII); a deposição de Giovanni da Parma por aderir às doutrinas de Joaquim da Fiore (cf. Capítulo XLVIII) e outras. Dentro do texto, estas polêmicas ganham ares de lenda.

“...la proposta anche in termini letterari e stilistici così efficace del mito del santo fondatore non di rado sdrammatizza e rende quasi ovvie, e dunque al di fuori della storia, scelte invece drammatiche nella vicenda dell'Ordine, assegnando alla rievocazione di quei fatti, o di quegli esempi, un valore lievemente astratto e ammirativo lontanissimo dalla dura concretezza della vita quotidiana..." (BALDASSARI, IN: MALATO, 2001, Vol. II, Cap. V, p. 286). 
Cada um destes capítulos é acompanhado de uma rubrica - que acaba por constituir o título do capítulo - e de um 'refrão final' constituído de um louvor dirigido a São Francisco ou a Jesus, ou a ambos.

Esta é uma importante obra na história da cultura italiana por, justamente, formar a principal visão popular da lenda franciscana. É um modo de ver a figura de São Francisco. Livro constituído de uma linguagem simples de quem olha o mundo como se fosse uma criança, mas que não deve ser tomado como ingênuo:

"La 'semplicità' o il 'candore' dei Fioretti, tante volte rilevati dai lettori, specie dei secoli successivi, nasconde per la verità una precisa scelta di campo, nella lunga e impari lotta fra Spirituali e Conventuali..." (BALDASSARI, IN: MALATO, 2001, Vol. II, Cap. V, pp. 284 -285).

"Il Francesco vulgato, il Francesco della scuola, il Francesco per l'infanzia, stilizzato, aggraziato e fiabesco, il Francesco che conquista un posto di singolarissimo privilegio nell'immaginazione nazionale, é anche sopratutto il Francesco dei Fioretti." (FORNI, 2003, p. VIII).

“...tanto più che I Fioretti non sono mai così ingenui some sembrano, anzi, sanno essere talora un testo polemico e "ideologico" di efficacia e intensità estraordinarie" (CARDINI, 1994, p. 123, grifo meu).

Assim, sua linguagem aponta para esta visão simples das coisas - infantil sem ser ingênua - e carrega-se de diminutivos ao fazer referência a Francisco de Assis. O próprio título é um diminutivo - fioretti.

"Anche il diminutivo Fioretti sembra accenare a quel senso d'infanzia in cui si rifugia la religione francescana. E frequenti sono i diminutivi, protezione verso la fragilità pura dell'infanzia: San Francesco è il 'poverello' di Cristo, 'omicciuolo', 'cattivello', egli e frate Leone devon esser presi per 'ladroncelli' vilissimi; e fra Leone è 'pecorella di Dio'; v'è anche un 'fanciullo fraticino'. [...] Una simile maniera di veder di ogni creatura e di ogni elemento la sua infanzia è un diminutivo tutto interiore [...]. Al modo stesso, su questo senso di cose infanti, l'immensità del mondo, di Dio, ha la smisurata e attonita grandezza che la meraviglia desta negli occhi dei bimbi." (FLORA, cit. IN: FORNI, 2003, p. IX).

Sobre o título Fioretti, que poderia corresponder a um termo em português como florilégio, antologia, temos que considerar o diminutivo empregado, a carga semântica e a 
conotação presentes dentro da língua italiana para o vocábulo6 - carga que traz também a idéia, na linguagem mais recente, de "sacrifício devocional".

Convém ainda esclarecer que, na Itália, paralelamente à leitura religiosa do texto, surge uma leitura parcial ou totalmente literária da obra. Alguns puristas - como o Padre Cesari (* 1760 - †1828) - propõem I Fioretti como modelo de linguagem. Hoje, a leitura da obra é quase exclusivamente literária na Itália - questões de narrativas populares, de tradução, vulgarização, entre outras, estão associadas a I Fioretti. No Brasil, que tipo de leitura temos de I Fioretti?

6 Fioretto: (1) s.m. 1 (lett.). Dimin. di fiore. 2. Parte scelta di qualcosa: il fioretto del cotone. 3 al pl. Scelta di racconti, avvenimenti aneddoti: I fioretti di San Francesco. 4. Sacrificio o rinuncia spontanea a fine di devozione: i fioretti di maggio. (ZINGARELLI, 2005). 
2. Subsídios de I Fioretti no Brasil

\subsection{As traduções de I Fioretti do século XX}

Antes de iniciar as considerações a respeito das traduções brasileiras analisadas nesta dissertação, farei algumas considerações gerais a respeito da obra I Fioretti no Brasil.

O primeiro aspecto importante é o pequeno número de traduções disponíveis da obra - duas:

- Adelino Capistrano

- Durval de Morais

E, já no final de minha pesquisa, descobri uma terceira:

- José Carlos Corrêa Pedroso

Esta última, publicada no site_http://cantodapaz.com.br/blog/category/08-os-fiorettide-sao-francisco, por se tratar de tradução não publicada em livro impresso, não a incluo na análise.

Segue-se a dificuldade em encontrá-las - são edições esgotadas e publicadas há bastante tempo; vendidas, portanto, somente em sebos ou encontradas em algumas bibliotecas.

\subsubsection{A tradução de Adelino Capistrano}

O trabalho deste tradutor foi publicado por duas editoras: 
- “I Fioretti de São Francisco - seguidos do 'Cântico do Sol”" - 2ª edição tradutor: Adelino Capistrano

\section{Atena Editora}

\section{Sem data.}

Cito acima a edição que tenho em mãos. Porém, acrescento que foram encontradas edições entre os anos de 1937 (encontrada nas bibliotecas da Universidade de Campinas coleção "Brito Broca”7 e em uma das bibliotecas municipais de Lisboa8) e 1958. Estas são datas estimadas da $1^{\mathrm{a}}$ e última edições; porém, não é possível afirmá-lo, já que a Editora Atena não mais existe.

- "I Fioretti de São Francisco - seguidos do 'Cântico do Sol”" -

\section{Tradutor: Adelino Capistrano}

\section{Editora Ediouro}

\section{Sem data.}

Mais uma vez a edição citada é a que tenho em mãos. As datas de primeira e últimas edições não são aqui citadas porque não foram encontradas edições datadas. A central de atendimento da editora também não soube dar tais informações.

As poucas informações sobre a editora Atena:

Publicou uma série de traduções em uma coleção denominada "Biblioteca Clássica" sendo I Fioretti parte desta coleção (volume XVI). Tal coleção possuía 40 volumes ou mais e incluía títulos como Elogio da Loucura, de Erasmo de Roterdam; Odisséia, de Homero; A República, de Platão; Gargantua, de Rabelais; Vida Nova, de Dante Alighieri9.

As traduções da referida coleção datam das décadas de 30, 40, 50, 60.

São edições encontradas em sebos e bibliotecas. Edição em capa dura e em brochura.

\section{Sobre a Ediouro:}

Editora fundada pelos irmãos gaúchos de Porto Alegre, Jorge e Antonio Gertum Carneiro, no Rio de Janeiro, durante o período da Segunda Guerra Mundial. Inicialmente com

7 http://www.iel.unicamp.br/biblioteca/britoBroca_lista.php 8 http://catalogolx.cm-lisboa.pt/ipac20/ipac.jsp?index=COLEC\&term=bibliotheca\#focus 9 Em anexo os títulos, datas, tradutores encontrados de tal coleção. 
o nome de Publicações Pan Americanas - importavam livros, papel vegetal e agenciavam assinaturas de revistas estrangeiras. Algum tempo depois, entra como sócio o imigrante alemão Fritz Israel Manheimer.

A guerra tornava a importação difícil, o que fez com que os sócios apostassem em traduções e edições de livros técnicos. Neste período, a empresa passou a se chamar Editora Gertum Carneiro S.A. Começaram a publicar livros de bolso e a revista Coquetel. Em 1961, a fusão da editora com a gráfica deu origem às Edições de Ouro.

Atualmente, a Ediouro conta com mais ou menos 3500 títulos.

A tradução de Adelino Capistrano foi publicada pela Ediouro também dentro de uma coleção - "Clássicos de Bolso". Não possui capa dura e - no site e na central de atendimento da editora - é dada como edição esgotada. São Francisco vem como autor da obra.

Temos ainda que a edição da Ediouro é acompanhada de ilustrações feitas por Frieda Wiegand.

\subsubsection{A tradução de Durval de Morais}

- “I Fioretti de São Francisco" - 4ª edição tradutor: Durval de Morais

\section{Editora Vozes}

\section{Ano: 1964}

Novamente, acima cito as informações da edição que tenho em mãos. Segundo a central de atendimento da Editora Vozes:

I Fioretti de São Francisco.

$\begin{array}{ccc}\text { Edições } & \text { Data } & \text { Tiragem } \\ 1^{\mathrm{a}} & 13 / 03 / 1964 & 3.000 \\ 2^{\mathrm{a}} & 21 / 12 / 1973 & 5.000 \\ 3^{\mathrm{a}} & 20 / 05 / 1981 & 3.000 \\ 7^{\mathrm{a}} & 10 / 04 / 1986 & 3.000\end{array}$


Não há informações sobre $4^{\mathrm{a}} 5^{\mathrm{a}}$ e $6^{\mathrm{a}}$ edição; provavelmente, foram feitas em outra editora.

Apesar das informações fornecidas pela editora, encontrei em um sebo virtual (http://www.traca.com.br/seboslivrosusados.cgi?mod=LV58254\&origem=resultadodetalhada), uma edição de I Fioretti de São Francisco, traduzida por Durval de Morais e publicada pela Vozes, que data do ano de 1940, porém indisponível para venda. Tal edição informa que a tradução foi baseada na edição de Antonio Cesari.

A editora Vozes é um editora brasileira, conhecida também como Vozes de Petrópolis; sediada em Petrópolis no estado do Rio de Janeiro, é gerenciada/administrada pela Congregação Franciscana Brasileira. Existe há mais de cem anos, sendo a mais antiga casa editorial do Brasil em funcionamento. Privilegia especialmente três grandes áreas: cultura, religião e catequese. A Vozes tem sido, desde seus primeiros tempos, o maior veículo de divulgação de cultura religiosa do Brasil, fomentando os movimentos intelectuais católicos. Muitos dos mais importantes livros escritos no mundo sobre temas cristãos foram, como a Imitação de Cristo, traduzidos pela empresa franciscana (http://pt.wikipedia.org/wiki/Editora_Vozes).

Sobre o tradutor Durval Borges de Morais (ou Moraes), é importante acrescentar: nasceu na Bahia, em 20 de novembro de 1882, e faleceu no Rio de Janeiro, em 05 de dezembro de 1948. Além de tradutor de I Fioretti di San Francesco, foi também poeta religioso. Padre franciscano convertido, sua obra poética é pouco conhecida, mesmo dentro da Igreja Católica10.

Em geral, constata-se que a versão dada pela Editora Vozes é semelhante ao original reproduzido por Newton, lembrando-se que o original deriva de manuscrito medieval que ainda não possui edição crítica. Ressalta-se, ainda, que as edições brasileiras não possuem qualquer indicação das fontes de onde foram extraídos os textos traduzidos.

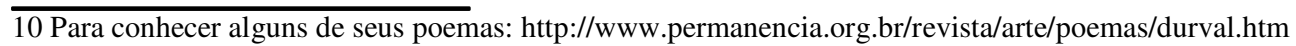




\title{
2.2 Convites à leitura: as introduções
}

A tradução como metonímia: durante a análise das traduções com as quais lido, esta afirmação parece ganhar vida.

As introduções de ambas as traduções são um ponto inicial interessante a ser analisado.

A introdução de Giulio David Leoni11 à tradução de Adelino Capistrano, dada pelas editoras Atena e Ediouro, apresenta não apenas a figura religiosa de São Francisco, mas também a figura histórica. Traz informações sobre a vida de Francesco Bernardone; traz datas, situa-o em seu tempo.

\footnotetext{
"A vida de Francisco Bernardone (o verdadeiro nome foi Giovanni, mas o pai, rico mercador que freqüentemente visitava a França, chamou o filho "Francesco", isto é, francês) é bastante conhecida; nem tem muito interesse para a leitura dos "Fioretti". Todavia, eis as datas fundamentais (...)" (LEONI, sem data, p. 07).
}

Adiante, G.D. Leoni insere esta figura histórica - faz referência ao movimento social que o franciscanismo representou para a época. Francisco não é tomado apenas por sua santidade religiosa, mas dentro de sua revolução social. Traz, também, a hesitação inicial da Igreja para com o movimento franciscano.

\begin{abstract}
"O outro aspecto de São Francisco refere-se à fôrça social do seu movimento humanitário em tempos tão trágicos de lutas políticas e religiosas." (LEONI, sem data, p. 08].

"Ao papa Inocêncio III pareceram demasiadamente ousados os princípios de São Francisco; tão ousados que várias vêzes vacilou antes de aprová-los (...)” (LEONI; p. 09).
\end{abstract}

Quanto à obra I Fioretti di San Francesco - daqui em diante, apenas IF -. é também sucinto, porém informativo. Cita a possível origem - a tradução/adaptação de Actus santi Francisci et sociorum eius - e o possível tradutor.

“... frei Ugolino da Montegiorgio teria reunido, em latim, os episódios mais importantes dessa tão grande personagem histórica; mas o "Floretum" de frei Ugolino se perdeu. Todavia, pelo que parece, do "Floretum" derivaram os "Actus

11 Giulio David Leoni foi professor de Literatura Italiana no Brasil - nas Universidades PUC e Mackenzie, e também tradutor. Da coleção Biblioteca Clássica da Editora Atena, de que faz parte a tradução de $I F$, foi organizador e escreveu boa parte das introduções às obras. 
santi Francisci et sociorum eius", que, em parte traduzidos, em parte livremente adaptados, deram lugar à redação toscana conhecida com o título de "Fioretti di San Francesco": alguns estudiosos indicam como autor da tradução e adaptação o franciscano florentino Giovanni de Marignoli (...)” (LEONI, sem data, p.10).

Deixa claro que "a atribuição é muito incerta".

Após tais informações, há uma exaltação do livro: há uma comparação entre I Fioretti e os Evangelhos.

\footnotetext{
"Nestes dias tão trágicos, em que a humanidade procura a paz e tem a ilusão de alcançá-la, a leitura de "Fioretti" é tão útil quanto a dos Evangelhos (...)" (LEONI, sem data, p. 11).
}

Ao final, Leoni faz considerações sobre a "fidelidade" do tradutor ao texto original.

\begin{abstract}
"Muito oportunamente foi respeitada pelo tradutor a linguagem obsoleta, a fim de não tirar à narração o ressaibo característico do tempo em que viveu e foi escrita: chocante singeleza e delicioso sabor de coisas antigas que constituem um dos seus principais motivos de interesse." (LEONI, sem data, p. 12).
\end{abstract}

Já Durval de Morais inicia sua introdução tratando da intraduzibilidade do vocábulo fioretti.

"I Fioretti. Nome intraduzível, que nos chega do passado de tantos séculos (...)”

“ I Fioretti. Através de todas as línguas devia passar como vocábulo único (...)” (MORAIS, 1964, p.05).

Sua introdução eleva não apenas o vocábulo fioretti - realmente de difícil tradução mas a figura de São Francisco que, aqui, não aparece como figura histórica, mas apenas em alta santidade. O texto ganha caráter de prece.

\footnotetext{
"Bem sabes, pai meu S. Francisco, como seria fácil ao teu indigno filho sobrecarregar esta introdução com o leve pêso de uma erudição sem pêso, reproduzindo tudo quanto se tem dito da origem, dos autores, da língua, da significação de Fioretti. Bem pouco difícil lhe seria tomar o bordão de heremita que fizesse crer aos outros atravessasse desertos sáfaros ou píncaros gelados, e caminhasse através de jardins plantados por muitos, e fingisse encontrar a rosa azul da legenda, para mostrar uma rosa qualquer tingida de anilina." (MORAIS, 1964, p. 05).
}

Cita também a origem controversa do texto. Menciona Actus Beati Francisci et Sociorum eius e não desconsidera a possível origem oral de sua composição, porém o faz de maneira a deixar bem claro que tal informação pouco importa. 


\begin{abstract}
"Que importa ao pobre trovador, arrancado por ti, pai meu S. Francisco, aos aplausos do mundo para o silêncio do teu silêncio, fôssem estas canções primitivamente escritas em latim, Actus Beati Francisci et Sociorum eius, e depois transferidas à língua vulgar; ou se, mais poèticamente ainda, foram contadas estas deliciosas històriazinhas pelos frades menores, sorridentes e humildes, nos pátios dos conventos, aos crepúsculos suavíssimos da Úmbria; ou se nasceram nas salas dos castelos, em longas noites hibernais, cantadas pelos cavaleiros andantes?" (MORAIS, 1964, p. 06).
\end{abstract}

Faz uma crítica à crítica. Coloca a obra $I F$ em um nível além de qualquer estudo, classificação, comentário. Apenas a contemplação, segundo ele, é digna da obra.

\footnotetext{
"Deixassem-nos sem história, sem filiação, sem averiguações críticas, sem análise, a esses divinamente anônimos "Fioretti", e eles seriam como estrelas iluminando as noites das almas, como cantos suavizando as agonias dos corações (...)” (MORAIS, 1964, p. 06).
}

Aqui, ainda não entramos na tradução do texto em si, mas já temos algumas informações sobre o pensamento dos tradutores ou até mesmo da editora diante do texto a ser traduzido. Enquanto em Morais fica claro o caráter "santo" da figura de Francisco de Assis e "evangélico", "sagrado", "intocável” do texto, Leoni descreve em sua introdução uma figura não apenas santa de Francisco de Assis, mas também histórica e revolucionária, e traz como grande motivo de interesse em IF a "chocante singeleza e delicioso sabor de coisas antigas" (LEONI, sem data, pp.11-12).

Enquanto um traz a questão da intraduzibilidade ao público, o outro se preocupa em sublinhar a fidelidade ao texto que se tentou manter na tradução.

Durval de Morais coloca o texto acima da análise, fala em intraduzibilidade de vocábulos, porém parece esquecer que seu texto é tradução; e, já que é tradução, é interpretação e, deste modo, um estudo, uma análise do texto original.

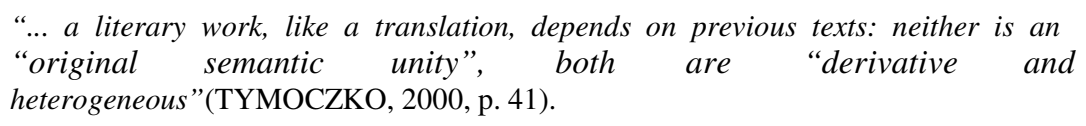

Capistrano não é autor de sua introdução. As considerações sobre a tradução não são feitas pelo tradutor; lidamos com a fala de outro que parece prever um leitor preocupado com a estética - "o sabor de coisas antigas" (LEONI, sem data, p.12) - e promete tradução literal. 


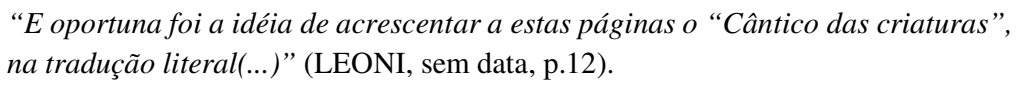

Só a afirmação "tradução literal" nos dá uma visão do conceito de tradução aqui tomado. Mais uma vez não há a idéia da tradução como novo texto, como leitura do tradutor. Temos um texto traduzido "literalmente" e, portanto, é o próprio original em outra língua.

Ambos os conceitos de tradução tomados nas referidas introduções ignoram/desconhecem o que chamamos de caráter metonímico do ato tradutório; caráter do qual seus trabalhos são, como qualquer tradução, um exemplo perfeito. Tomam sim a parte (tradução) pelo todo (original), mas não o fazem de maneira consciente. A parte é o todo e só; ou melhor, não existe parte: o todo em português é a representação do todo em italiano.

Interessante aqui apenas ressaltar que ambos trazem conceitos do ato tradutório semelhantes. Mas o mais interessante surge da comparação entre as duas exposições. Já aqui, o mesmo conceito toma formatos diferentes e são bons exemplos de que toda escritura passa pelo processo de interpretação.

"It is agreed that the content, form, and performance techniques of any given traditional song or tale, for example, derive from established patterns that the teller or singer inherits and in turn passes on to those who succeed him." (TYMOCZKO, 2000, p. 41 - grifo meu).

Os textos introdutórios das duas traduções são bem diferentes, como se pode notar. Dessa diferença surge a questão do "quem fala" e do "para quem se fala" - em outras palavras, quem traduz e para quem traduz são de fundamental importância.

“... a autoria não é individualista, mas coletiva: a forma do trabalho não se origina simplesmente com o autor como 'seu estilo e expressões próprios', mas é de fato uma colaboração com um grupo social específico, na qual o autor leva em consideração os valores culturais característicos daquele grupo. (...) Na tradução, a interpretação do texto estrangeiro e o fato de destinar-se a um público são mutuamente determinantes, embora numa dada tradução um desses fatores possa ter mais influência do que outro: o público projetado pode moldar de forma decisiva a interpretação do tradutor, ou a interpretação do tradutor pode definir de modo decisivo o público.” (VENUTI, 2002, pp. 116 e 118 - grifo meu). 
Tendo tomado o texto como algo solene - uma prece, elevada a ponto de não aceitar questionamento, críticas ou estudos - , Durval de Morais teria definido o seu público? Ou o seu público - certamente religioso, católico - o teria levado a interpretar o texto de tal maneira?

Para quem teria traduzido Adelino Capistrano? Até que ponto as palavras de Leoni refletem o trabalho do tradutor?

São indagações a que as considerações das páginas seguintes talvez ajudem a responder. 


\section{Comentários às traduções brasileiras de I Fioretti di San Francesco}

\subsection{Rubrica, Saudação Final, Paragrafação}

As cinqüenta e três narrativas contidas em IF vêm precedidas de uma rubrica, isto é, título ou entrada que constitui indicação geral do assunto. Tal rubrica é típica dos manuscritos medievais, o que deve ser levado em consideração quando se traduz um texto como $I F$.

Neste item do trabalho, exponho o cotejo e a análise - obra original e traduções - de tais títulos introdutórios.

Na edição de Atena e Ediouro, temos as rubricas como em Newton; porém, constatamse algumas questões nos seguintes fioretti ${ }^{12}$ :

$F X$ :

Newton Atena/Ediouro

\begin{tabular}{|c|c|}
\hline $\begin{array}{l}\text { "Come frate Masseo, } \\
\text { quasi proverbiando, } \\
\text { disse a santo Francesco } \\
\text { che a lui tutto il mondo } \\
\text { andava dirieto; ed egli } \\
\text { rispuose che ciò era a } \\
\text { confusione del mondo e } \\
\text { grazia di Dio; perch'io } \\
\text { sono il pì̀ vile del } \\
\text { mondo." - (p. 30). }\end{array}$ & $\begin{array}{l}\text { "De como Irmão } \\
\text { Masseo, } \\
\text { escarnecendo, disse a S. } \\
\text { Francisco que o mundo } \\
\text { seguia empós dêle, e S. } \\
\text { Francisco respondeu } \\
\text { que isso era para } \\
\text { confusão do mundo, } \\
\text { graça de Deus." - (p. } \\
\mathbf{4 9} \text { e p. } \\
\text { respectivamente). }\end{array}$ \\
\hline
\end{tabular}

Há, como se vê, omissão de trecho.

12 Todos os grifos presentes são meus. Daqui por diante cada fioretto será indicado simplesmente por $F$ (exemplo - FI indica Fioretto I) 


\section{F XXVIII:}

\begin{tabular}{|l|l|}
\hline \multicolumn{1}{|c|}{ Newton } & \multicolumn{1}{c|}{ Atena/Ediouro } \\
"D’uno rapimento che & "De um arrebatamento, \\
venne a frate Bernardo, & que teve S. Bernardo; \\
ond'egli stette dalla & pelo que êle ficou da \\
mattina insino a nona & manhã até às onze e \\
ch'egli non si senti." - & meia, sem que se \\
(p. 57). & sentisse."-(p. 119 e p. \\
& 81 respectivamente). \\
\hline
\end{tabular}

Aqui a tradução toma o horário canônico "nona" por "onze e meia". Além de adaptar o vocábulo - trazer as horas laicas ao invés das horas litúrgicas -, o tradutor ainda o faz de maneira errada. A "nona" corresponde às "três horas da tarde" e não às "onze e meia" como na referida tradução.

Nota-se, ainda, o início da discrepância entre a introdução dada por Leoni e a tradução oferecida por Capistrano. Enquanto Leoni promete um texto ao "sabor antigo", Capistrano parece oferecer algo sem "o ressaibo característico do tempo" (LEONI, sem data, p.11).

$F X X X I I$ e $X L I V$ :

\begin{tabular}{|c|c|}
\hline Newton & Atena/Ediouro \\
\hline $\begin{array}{l}\text { "Come frate Masseo } \\
\text { impetrò da Cristo la } \\
\text { virtù della santa } \\
\text { umiltà." - (p. 62). }\end{array}$ & $\begin{array}{l}\text { "De como Irmão } \\
\text { Masseo impetrou de } \\
\text { Cristo a virtude da sua } \\
\text { humildade." - (p. } 133 \text { e } \\
\text { p. } \\
\text { respectivamente). }\end{array}$ \\
\hline
\end{tabular}

\begin{tabular}{|l|l|}
\hline \multicolumn{1}{|c|}{ Newton } & \multicolumn{1}{|c|}{ Atena/Ediouro } \\
"Come a frate Currado & "De como a Mãe de \\
apparve la madre di & Cristo, e S. João \\
Cristo e santo Giovanni & Evangelista, \\
Vangelista e santo & apareceram a Irmão \\
Francesco; e dissegli & Conrado; e disseram- \\
quale di loro porto più & lhe qual dêles sofreu \\
dolore della passione di & maiores dores pela \\
Cristo." - (p. 76). & $\begin{array}{l}\text { Paixão de Cristo."-(p. } \\
\mathbf{1 6 9} \text { e p.111 } \\
\end{array}$ \\
& respectivamente). \\
\hline
\end{tabular}

Notem-se as omissões em ambas as rubricas. 
F XLVII :

\begin{tabular}{|c|c|c|c|}
\hline Newton & Garzanti & Atena/Ediouro & Vozes \\
\hline $\begin{array}{l}\text { "Di quello santo frate a } \\
\text { cui la Madre di Cristo } \\
\text { apparve, quando era } \\
\text { infermo, ed arrecogli } \\
\text { tre bossoli di di } \\
\text { lattovaro." - (p. 80). }\end{array}$ & $\begin{array}{l}\text { "Come uno frate } \\
\text { essendo infermo a } \\
\text { morte, venne la Vergine } \\
\text { Maria con tre bossoli di } \\
\text { lattovaro, e sanollo." - } \\
\text { (p. 140). }\end{array}$ & $\begin{array}{l}\text { "Daquele Santo Irmão, } \\
\text { a quem a Mãe de Cristo } \\
\text { apareceu quando estava } \\
\text { enfermo, trazendo-lhe } \\
\text { três copos de } \\
\text { remédio." - (p. } 179 \text { e } \\
\text { p. } \\
\text { respectivamente). }\end{array}$ & $\begin{array}{l}\text { "Daquele santo frade ao } \\
\text { qual a mãe de Cristo } \\
\text { apareceu, quando } \\
\text { estava enfermo, e lhe } \\
\text { trouxe três caixas de } \\
\text { eletuário." - (p. 95). }\end{array}$ \\
\hline
\end{tabular}

Aqui se trata de escolhas lexicais diversas.

\section{lattovaro $^{13:}$}

1. elettuario - antico preparato farmacêutico semidenso o sciroppo attenuto mescolando medicamenti com miele, sciroppo e conserve e sim.

Em se tratando do vocábulo italiano lattovaro, temos as seguintes traduções: remédio dada por Adelino Capistrano - e eletuário - por Durval de Morais.

eletuário ${ }^{14:}$ medicamento de consistência branda, composto, em geral, de pós, extratos e folhas de vegetais, de mistura com mel ou açúcar.

Mais uma vez, o "sabor das coisas antigas" desaparece em Capistrano.

IF possuem, ao final de cada capítulo seu, uma saudação final, um louvor a São Francisco e a Jesus. Este louvor também é característico.

Adelino Capistrano apenas apresenta o refrão final em FII e FIII.

13 Todos as definições dos vocábulos em italiano foram extraídas de Zingarelli, 2005.

14 As definições dos vocábulos em português foram extraídas de Aurélio. 
F II - “...e começada a pobreza evangélica, ofereceu-se despido nos braços do Crucificado; o qual seja por nós abençoado em secula seculorum. Amen." (CAPISTRANO, sem data, p. 19).

F III - "Em louvor, e glória de Jesus Cristo, e do pobrezinho Francisco. Amém." (CAPISTRANO, sem data, p. 23).

Simplesmente se omite a presença de qualquer tipo de saudação final em todos os outros fioretti, o que, novamente, compromete a promessa de Leoni quanto ao respeito à época em que viveu e foi escrita a obra original.

A tradução de Durval de Morais é semelhante ao original dado pela edição Garzanti. Apresenta "problemas" nos seguintes fioretti:

$F X X I X:$

\begin{tabular}{|l|l|l|}
\hline \multicolumn{1}{|c|}{ Newton } & \multicolumn{1}{|c|}{ Gozes } & \multicolumn{1}{c|}{ Garzanti } \\
"A laude di Gesù & “...o que é bendito in & "Il quale è benedetto in \\
Cristo e del poverello & $\begin{array}{l}\text { secula, etc. Amém.”- } \\
\text { saecula saeculorum. }\end{array}$ \\
Francesco. Amen." - & (p. 64). & Amen." - (p. 95). \\
(p. 58). & & \\
\hline
\end{tabular}

“in saecula saeculorum" é traduzido como "in secula, etc". A presença de "etc" no texto em português resume o texto em italiano, dando por conhecida a continuação do louvor.

F XXIV; XXVII; XXXVI; XLIV - omissão do refrão final.

F XLVII e LIII:

\begin{tabular}{|c|c|c|}
\hline Newton & Vozes & Garzanti \\
\hline $\begin{array}{l}\text { "A laude di Gesù Cristo } \\
\text { e del poverello } \\
\text { Francesco. Amen." - } \\
\text { (p. 81) }\end{array}$ & "Amém." - (p. 96) & $\begin{array}{l}\text { "A laude di Dio. } \\
\text { Amen." - (p. 142). }\end{array}$ \\
\hline
\end{tabular}


"A laude di Dio. Amen" = “Amém”.

\begin{tabular}{|l|c|l|}
\hline \multicolumn{1}{|c|}{ Newton } & \multicolumn{1}{|c|}{ Vozes } & \multicolumn{1}{c|}{ Garzanti } \\
"A laude di Gesù Cristo & “Amém.”-(p. 108). & "A laude di Cristo. \\
e del poverello & & Amen." - (p. 162). \\
$\begin{array}{l}\text { Francesco. Amen." - } \\
\text { (p.91). }\end{array}$ & \\
\hline
\end{tabular}

“A laude di Cristo. Amen" = "Amém”.

Em ambos os fioretti, portanto, parte da saudação final foi omitida na tradução.

$$
* * * * * *
$$

Temos, no que diz respeito à paragrafação, uma diferença bem representativa se considerarmos o original dado pela Tascabili Newton. Este parece ser o único que é dividido em parágrafos. Temos (à esquerda temos o número do capítulo, à direita o número de parágrafos):

\begin{tabular}{|c|c|c|c|c|c|}
\hline $\mathrm{I}-1$ & $X-2$ & XIX - 3 & XXVIII - 4 & XXXVII - 5 & XLVI - 4 \\
\hline II -6 & $\mathrm{XI}-6$ & $\mathrm{XX}-2$ & XXIX -8 & XXXVIII - 4 & XLVII - 5 \\
\hline III -4 & XII - 3 & XXI - 6 & $\mathrm{XXX}-4$ & XXXIX - 3 & XLVIII - 6 \\
\hline IV -4 & XIII -4 & XXII - 4 & XXXI - 4 & $\mathrm{XL}-4$ & XLIX - 11 \\
\hline$V-4$ & XIV - 2 & XXIII - 2 & XXXII - 5 & XLI - 6 & $\mathrm{~L}-2$ \\
\hline $\mathrm{VI}-4$ & $X V-5$ & XXIV - 5 & XXXIII -4 & XLII - 6 & $\mathrm{LI}-5$ \\
\hline VII -5 & $\overline{X V I}-6$ & $\overline{X X V}-6$ & XXXIV - 4 & XLIII -4 & LII -3 \\
\hline VIII - 3 & XVII - 4 & XXVI - 12 & XXXV - 3 & XLIV -3 & LIII - 4 \\
\hline IX -2 & XVIII - 6 & XXVII - 5 & XXXVI - 3 & XLV - 7 & \\
\hline
\end{tabular}

No original dado pela Garzanti, temos uma paragrafação totalmente diferente sendo que todos os capítulos possuem parágrafos únicos com as seguintes exceções:

II - 2; IV - 3; VI - 2; VIII - 2 .

Quanto às traduções, temos que a dada por Durval de Morais possui parágrafo único em todos os capítulos. A de Adelino possui parágrafo único em todos os capítulos, com exceção de apenas um - XXXII -, que possui dois parágrafos. 


\subsection{A parte pelo todo: as escolhas lexicais dos tradutores}

Como já explicitado anteriormente, ao lidarmos com as traduções de $I F$, lidamos com duas interpretações deste texto. Tais trabalhos em língua portuguesa podem considerar-se partes do todo original. Isto porque toda tradução comporta escolhas em diversos graus desde a opção pelo português como língua de chegada até a escolha de termos lexicais coerentes com a proposta de tradução.

\footnotetext{
"La configurazione dell'Autore Modello dipende da tracce testuali ma pone in gioco l'universo di ciò che sta dietro al testo, dietro il destinatario e probabilmente davanti al testo e al processo di cooperazione (nel senso che dipende dalla domanda: 'cosa voglio fare di questo testo?').” (ECO, 1983, p. 66).
}

"Per organizzare la propria strategia testuale un autore deve riferirsi a una serie di competenze (espressione più vasta che 'conoscenza di codici') che conferiscano contenuto alle espressioni che usa.” (ECO, 1983, p.55).

E aqui se encontra toda a questão para o tradutor: o que quero fazer deste texto?

No presente ítem, exponho casos em que diferentes traduções podem restringir o pleno alcance do vocábulo original.

\section{- Diminutivos}

Neste ítem, trago exemplos das traduções analisadas de escolhas lexicais que se referem a vocábulos em italiano que se encontram na forma diminutiva.

Aqui ressalto a importância dos diminutivos dentro de $I F$ - muito utilizados durante toda a obra, sendo o próprio título um diminutivo: Fioretti (cf. p. 15 - citação de FLORA, IN: FORNI, 2003).

\footnotetext{
Nota da Garzanti (p. 57) - celluzza: 'l'uso frequente dei diminutivi pare voglia sfumare le cose di umiltà per renderle più armoniche a quelle anime.'
}

É importante colocar também a rica quantidade de sufixos que formam os diminutivos na Língua Italiana. Se considerarmos as diversas possibilidades, depararemo-nos com : piattino, 
stellina; panetto, cappannetta; poverello, pecorella; lumicino, pellicina; puntolino, bestiolina; campicello, navicella; porticiolo, omicciuolo, asticciola; giovanotto; orsacchiotto; cosuccia; celluzza; canzoncina, ladroncello.

Tal variedade na Língua Italiana acarreta problemas para o tradutor brasileiro em sua escolha tradutória.

Levadas tais notas em consideração, eis as soluções tradutórias adotadas por Vozes e Atena/Ediouro para os diminutivos dentro de $I F$ :

figliuolo (passim)

Nenhuma das duas traduções, em nenhum momento, traz para o português o diminutivo afetivo presente no vocábulo italiano. Em todos os fioretti em que aparece figliuolo, ambas as edições (Vozes e Atena/Ediouro) trazem como solução "filho".

omicciuolo (FIII - Newton, p. 20, Garzanti, p.13; F XXX - Newton, p. 61, Garzanti, p. 101) As traduções:

F III

“Ó pobre homenzinho, por que estás perturbado?” (MORAIS, 1964, p. 13 - grifo meu).

“Ó pobre homenzinho, por que estás perturbado?" (CAPISTRANO, sem data, p. 22 - grifo meu).

Neste fioretto, ambas as traduções respeitam tal característica de $I F$ - ainda que Relativamente, se considerarmos as diversas possibilidades do diminutivo em Língua Italiana.

FXXX

"De onde te vem tanta presunção, filho de Pedro Bernardão, vil homenzinho..." (MORAIS, 1964, p. 68 - grifo meu). 
"Por que tanta presunção, filho de Pedro Bernardoni, vil homúnculo..." (CAPISTRANO, sem data, p. 128 - grifo meu).

Novamente, ambas as traduções respeitam o diminutivo, porém, de maneiras diferentes. Durval de Morais mantém-se coerente com a primeira escolha, enquanto Adelino Capistrano traz uma nova forma para o mesmo vocábulo italiano.

poverello (passim).

Com este termo, temos nos originais o uso do diminutivo da palavra "povero". É importante notar que tal forma é muito usada durante toda a obra para designar a figura de $\mathrm{S}$. Francisco (cf. F II, F VI, F XIX) e seus discípulos (cf. F V, F XVIII, F XXXVII).

Aqui, então, nos deparamos com uma forma do diminutivo: poverello; sendo ainda possíveis as formas poveretto, poverino, poveruccio.

Constata-se a edição Vozes respeitando - ainda que relativamente - sempre o diminutivo, Atena/Ediouro por vezes sim, por vezes não:

F II

“...e preparava-se pelo seu pobrezinho Francisco...” (MORAIS, 1964, p. 11 - grifo meu).

“...e dispunha que o seu Francisco pobrezinho..." (CAPISTRANO, sem data, p. 16 - grifo meu).

FV

“...que assim começava a aumentar os pobrezinhos discípulos da cruz...” (MORAIS, 1964, p.

19 - grifo meu).

“...assim, começava a multiplicar os pobres discípulos da cruz...” (CAPISTRANO, sem data,

p. 33 - grifo meu). 
FVI

"Bendito sejas, pois, por Nosso Senhor Jesus Cristo e por mim, seu pobrezinho

servo..."

(MORAIS, 1964, p. 20 - grifo meu).

"Bendito sejas, pois, por nosso Senhor Jesus Cristo e por mim,

pobre servo seu..."

(CAPISTRANO, sem data, p. 36 - grifo meu).

F XIII

\begin{tabular}{|c|c|c|c|}
\hline & Garzanti & Atena/Ediouro & Vozes \\
\hline $\begin{array}{l}\text { “...era riputato un vile } \\
\text { poverello da chi non lo } \\
\text { conosceva, non accattò } \\
\text { se non parecchi bocconi } \\
\text { e pezzuoli di pane } \\
\text { secco..." - (p. 33). }\end{array}$ & $\begin{array}{l}\text { “...e però era riputato } \\
\text { uno vile poverello da } \\
\text { chi nol conosceva, non } \\
\text { accattò se non parecchi } \\
\text { bocconi e pezzuoli di } \\
\text { pane secco." - (p. 44). }\end{array}$ & $\begin{array}{l}\text { “...e por ser reputado } \\
\text { um vil pobretão por } \\
\text { quem não o conhecesse, } \\
\text { conseguiu apenas } \\
\text { alguns bocados e } \\
\text { pedaços de pão seco..." } \\
\text { - (p. 57-58 e p. } \mathbf{4 4} \\
\text { respectivamente). }\end{array}$ & $\begin{array}{l}\text { “...e por isso reputado } \\
\text { um vil pobrezinho por } \\
\text { quem não o conhecia, } \\
\text { só recolheu algumas } \\
\text { côdeas e pedacinhos de } \\
\text { pão seco." - (p. 30). }\end{array}$ \\
\hline
\end{tabular}

Neste exemplo, nas traduções brasileiras, temos que Vozes preserva o diminutivo em seu trabalho - “...reputado vil pobrezinho por quem não o conhecia.” (MORAIS, 1964, p. 30 grifo meu), mas, diante de tal gama de possibilidades no italiano, a tradução acaba restringindo as conotações do "ello" original.

Enquanto Atena/Ediouro não só deixa perder-se o diminutivo, como insere um aumentativo depreciativo - “...e por ser reputado um vil pobretão por quem não o conhecesse..." (CAPISTRANO, sem data, p.58 - grifo meu).

\section{F XVIII}

"Deveras Deus dispensa cuidado especial a êstes santos pobrezinhos...” (MORAIS, 1964, p.

43 - grifo meu).

"Na verdade, Deus tem um cuidado especial com êstes santos pobres..." (CAPISTRANO, sem data, p. 78 - grifo meu).

\section{F XIX}

“...pelo amor de Deus e do pobrezinho...”(MORAIS, 1964, p. 45 - grifo meu). 
“...pelo amor de Deus, e de mim, pobrezinho...” (CAPISTRANO, sem data, p. 83 - grifo meu).

\section{F XXXVII}

“...seja por vontade de Cristo concedida a nós pobrezinhos e débeis...” (MORAIS, 1964, p.

78 - grifo meu).

“...que praza a Jesus Cristo conceder a nós, pobres débeis...” (CAPISTRANO, sem data, p.

144 - grifo meu).

$F X L$

“Ofereceste o censo a Nosso Senhor Jesus Cristo, o qual como pobrezinho não tinha com que pagar." (MORAIS, 1964, p. 82 - grifo meu).

"Ofereceste tributo a nosso Senhor Jesus Cristo, o qual êle, como pobre, não tinha com o que

pagar." (CAPISTRANO, sem data, p. 154 - grifo meu).

pecorella (passim)

No presente exemplo, temos Vozes preservando a forma diminutiva do vocábulo ("ovelhinha") - ainda que a deixe de lado em $F$ XVII e $F$ XXIII. Em Atena/Ediouro temos "ovelha" em todas as situações em que "pecorella" aparece. 
navicella $(F$ VII $)$

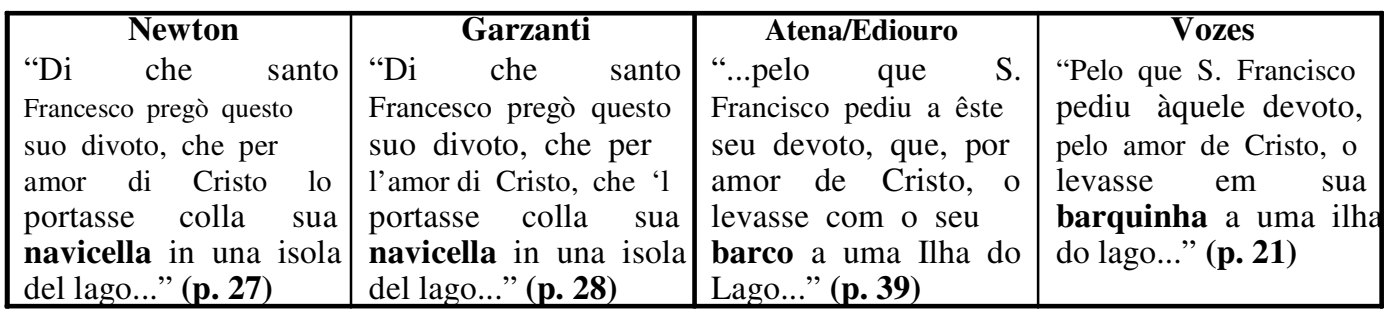

Vozes traz "barquinha" e Atena/Ediouro "barco". Há realmente uma perda em Atena/Ediouro neste exemplo, considerando $I F$ uma obra literária.

panetti ( $F$ VII - Newton, p. 27; Garzanti, pp. 28 e 29).

Exemplo em que ambas as traduções "respeitam” a forma diminutiva do vocábulo.

“...e S. Francisco só levou consigo dois pãezinhos.”; "E ali passou tôda a quaresma sem comer nem beber, além da metade de um daqueles pãezinhos...”; “...o qual achou dois pãezinhos, um inteiro e outro pela metade.” (MORAIS, 1964, p. 22 - grifos meus).

“...e S. Francisco não levou consigo senão dois pãezinhos.”; "E aí esteve tôda a Quaresma, sem beber e sem comer, a não ser a metade de um daqueles pãezinhos...”; “...o qual encontrou os dois pãezinhos, um inteiro, e o outro pela metade...” (CAPISTRANO, sem data, p. 40 - grifos meus).

capannetta (F VII - Newton, p. 27; Garzanti, p. 29)

Vozes traduz "cabana” e Atena/Ediouro "cabanazinha”. 
ladroncelli (F VIII - Newton, p. 28 ; Garzanti, p. 32).

Outra vez, Vozes traz solução tradutória que leva em consideração o diminutivo e Atena/Ediouro solução que não o leva em conta - "ladrõezinhos" e "ladrões".

cattivello ( $F I X)$

\begin{tabular}{|c|c|c|c|}
\hline Newton & Garzanti & Atena/Ediouro & Vozes \\
\hline $\begin{array}{l}\text { "O frate Francesco } \\
\text { cattivello, pensi tu che } \\
\text { Dio arà misericordia di } \\
\text { te? con ciò sia cosa che } \\
\text { tu abbi commessi tanti } \\
\text { peccati contra } \\
\text { Padre..." (p. 29) }\end{array}$ & $\begin{array}{l}\text { "O frate Francesco } \\
\text { cattivello pensi tu che } \\
\text { Iddio avrà misericordia } \\
\text { di te, con ciò sia cosa } \\
\text { che tu abbi commessi } \\
\text { tanti peccati contra al } \\
\text { Padre..." (p. 35) }\end{array}$ & $\begin{array}{l}\text { "Ó Irmão Francisco, } \\
\text { desgraçadinho, pensas } \\
\text { que Deus terá } \\
\text { misericórdia de ti, } \\
\text { embora haja cometido } \\
\text { tantos pecados contra o } \\
\text { pai..." (p. } \mathbf{4 6})\end{array}$ & $\begin{array}{l}\text { “Ó irmão Francisco } \\
\text { miserável, pensas tu } \\
\text { que Deus há de ter } \\
\text { misericórdia de ti; não é } \\
\text { tão certo que tenhas } \\
\text { cometido tantos } \\
\text { pecados contra o pai...” } \\
\text { (p. 25) }\end{array}$ \\
\hline $\begin{array}{l}\text { "O frate Francesco } \\
\text { cattivello, etc..." (p. 29) }\end{array}$ & $\begin{array}{l}\text { "O frate Francesco } \\
\text { cattivello, etc..." (p. 35) }\end{array}$ & $\begin{array}{l}\text { "Ó Irmão Francisco, } \\
\text { desgraçadinho, etc..." } \\
\text { (p. 46) }\end{array}$ & $\begin{array}{l}\text { "Ó irmão Francisco } \\
\text { miserável..." (p. 25) }\end{array}$ \\
\hline $\begin{array}{l}\text { "O frate Francesco } \\
\text { cattivello, pensi tu che } \\
\text { Iddio } \\
\text { misericordia di te?" (p. } \\
\text { 30) }\end{array}$ & $\begin{array}{l}\text { "O frate Francesco } \\
\text { cattivello, pensi tu che } \\
\text { Iddio abbia } \\
\text { misericordia di te?" (p. } \\
\text { 36) }\end{array}$ & $\begin{array}{l}\text { "O Irmão Francisco, } \\
\text { desgraçadinho, pensas } \\
\text { que Deus terá } \\
\text { misericórdia de ti?" (p. } \\
\text { 47) }\end{array}$ & $\begin{array}{l}\text { "Ó irmão Francisco } \\
\text { miserável, pensas que } \\
\text { Deus terá misericórdia } \\
\text { de ti ?" (p. 26) }\end{array}$ \\
\hline
\end{tabular}

Neste trecho, é o próprio Francisco que refere a si mesmo como cattivello. 
pezzuoli $(F X I I I)$

\begin{tabular}{|c|c|c|c|}
\hline Newton & Garzanti & Atena/Ediouro & Vozes \\
\hline $\begin{array}{l}\text { "...era riputato un vile } \\
\text { poverello da chi non lo } \\
\text { conosceva, non accattò } \\
\text { se non parecchi bocconi } \\
\text { e pezzuoli di pane } \\
\text { secco..." - (p. 33). }\end{array}$ & $\begin{array}{l}\text { "...e però era riputato } \\
\text { uno vile poverello da } \\
\text { chi nol conosceva, non } \\
\text { accattò se non parecchi } \\
\text { bocconi e pezzuoli di } \\
\text { pane secco." - (p. (44). }\end{array}$ & $\begin{array}{l}\text { “...e por ser reputado } \\
\text { um vil pobretão por } \\
\text { quem não o conhecesse, } \\
\text { conseguiu apenas } \\
\text { alguns bocados e } \\
\text { pedaços de pão seco...” } \\
\text { - (p. } \mathbf{5 7 - 5 8} \text { e p. } \mathbf{4 4} \\
\text { respectivamente). }\end{array}$ & $\begin{array}{l}\text { “...e por isso reputado } \\
\text { um vil pobrezinho por } \\
\text { quem não o conhecia, } \\
\text { só recolheu algumas } \\
\text { côdeas e pedacinhos de } \\
\text { pão seco.” - (p. 30). }\end{array}$ \\
\hline
\end{tabular}

Mais uma vez, o uso do diminutivo é, parcialmente, respeitado por Vozes - "pedacinhos de pão" e não o é por Atena/Ediouro - "pedaços de pão". Lembrando sempre a variedade dos diminutivos dentro da Língua Italiana (pezzuoli, pezzetti, pezzettini...).

orciuoli $(F X V I I I)$.

\begin{tabular}{|c|c|c|c|}
\hline Newton & Garzanti & Atena/Ediouro & Vozes \\
\hline 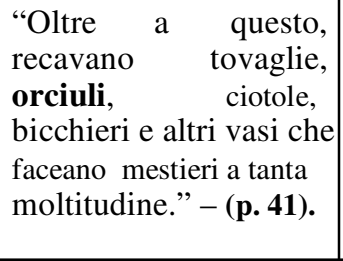 & $\begin{array}{l}\text { "Oltr'a questo, } \\
\text { recavano tovaglie e } \\
\text { orciuoli e bicchieri e } \\
\text { altri vasi, che faceano } \\
\text { mestieri a tanta } \\
\text { moltitudine...." - (p. } \\
\text { 62). }\end{array}$ & $\begin{array}{l}\text { "Além disso, traziam } \\
\text { toalhas, cântaros, } \\
\text { escudelas, copos e } \\
\text { outros vasos, de que } \\
\text { carecia } \quad \text { aquela } \\
\text { multidão..."- (p. } \mathbf{7 8} \text { e } \\
\text { p.57 respectivamente). }\end{array}$ & $\begin{array}{l}\text { "Além disso traziam } \\
\text { toalhas, púcaros, } \\
\text { garrafas, copos e outros } \\
\text { vasos de que tal } \\
\text { multidão havia mister." } \\
\text { - (p. 43). }\end{array}$ \\
\hline
\end{tabular}

orciolo:

1. dim. di orcio;

2. brocca, boccale.

orcio: vaso di terracotta, talvolta anche smaltata e decorata, con corpo panciuto, generalmente a due manici e bocca ristretta. 
púcaro:

1. pequeno vaso com asa, ordinariamente destinado a extrair líquidos de outros recipientes maiores.

2. pequeno vaso de toucador, para depósito de pó de arroz.

cântaro: vaso grande e bojudo, com uma ou duas asas, de barro ou de folha, para líquidos.

O termo italiano, além de não ser completamente abarcado pelos termos escolhidos em português, ainda acaba perdendo sua menção diminutiva. Mais importante do que a perda do sentido não completamente abarcado, é a perda da forma, já que o uso dos diminutivos em $I F$ é algo que não pode ser deixado de lado.

- $\quad$ frate (passim); suora $(F X V, F X V I, F X X X I I I, F X X X V)$.

O vocábulo italiano Ifratel aparece por diversas vezes no texto de $I F$ por se tratar de uma palavra-chave, já que se trata de historietas dos companheiros de Francisco de Assis e de membros do franciscanismo.

frate:

1. religioso in un ordine monastico cattolico: $f$. di San Francesco, di San Domenico.

2. fratello; amico, persona cara: Laudato si', mi' Signore, per f. vento (Francesco d'Assisi).

Tal vocábulo é traduzido pela Atena/Ediouro através do português |irmãol.

irmão:

1. filho do mesmo pai e da mesma mãe, ou só do mesmo pai (irmão consangüíneo) ou só da mesma mãe (irmão uterino), em relação a outro (s) filho (s).

2. membro de confraria ou de irmandade.

3. correligionário, confrade, camarada. 
4. frade ou religioso que não recebe as ordens sacras, embora tenha emitido os votos.

5. membro da maçonaria.

6. frade que não exerce cargos superiores: Os franciscanos guardam estes lugares santos. Um irmão espanhol nos fala das descobertas... dos sábios sobre as origens da velha Basílica (José Lins do Rego, Gregos e Troianos, p.152).

Já na edição da Vozes, o termo é traduzido por |freil e, por vezes |fradel.

frei: proclítica, apocapada, de freire, quando precede o nome ou apelido: Frei Boaventura.

freire: membro das antigas ordens militares; irmão.

frade: religioso pertencente à comunidade onde se emitem votos solenes. Frade menor franciscano.

As traduções, apesar de estarem de acordo com o vocábulo original, são diferentes. Esta diferença ocasiona matizes diferentes de leitura, já que, apesar de os termos lirmãol e |freil e |fradel estarem ligados semanticamente, os últimos trazem sim uma carga religiosa maior que o primeiro. O termo italiano |fratel tem em si o dois matizes.

O termo lsuoral - nos fioretti sopracitados é traduzido por Durval de Morais - Vozes através do vocábulo português |soror|.

soror: tratamento dado às freiras; é o feminino de frei.

Enquanto Adelino Capistrano - Atena/Ediouro - traz lirmãl como solução tradutória em $F X V, F X V I$, mas traz também lsororl em $F X V, F X X X I I I$ e $F X X X V$.

Aqui o tradutor de Vozes é coerente com a escolha lexical feita anteriormente ao traduzir o vocábulo |fratel - |freil, |fradel. Já em Atena/Ediouro temos alternância da solução tradutória. 
Temos, então, uma leitura mais clericalizada e coerente por parte de Vozes se comparada à leitura de Atena/Ediouro.

- $\quad$ covacciolo (F VII - Newton, p. 27; Garzanti, p. 29)

Temos “cova" em Vozes e "covil” em Atena/Ediouro.

covacciolo:

1. luogo dove dorme e si riposa l'animale, detto spec. di uccelli, topi, ghiri.

2. letto, giaciglio dell'uomo.

Em ambas as traduções, temos a noção também de buraco na terra em que se escondem animais, porém o sentido primeiro e muito mais forte de ambos os vocábulos é bem diferente: "cova" nos remete a morte e "covil" ao esconderijo de cobras, ladrões - sentidos negativos não presentes no original.

- $\quad \operatorname{cibo}(F X V$ : Newton, p. 36, Garzanti, p. 51; F XL: Newton, p. 70, Garzanti, p. 120; $F$ XLI: Newton, p. 72, Garzanti, p. 123; F LIII: Newton, p. 89, Garzanti, p. 159).

Zingarelli Maggiore:

1. ciò che serve all'alimentazione umana e animale;

2. vivanda, pietanza.

Atena/Ediouro traduz por lalimentol em $F X V$ e $X L I$ e por $\mid$ comidal em $F X L$. A editora Vozes por Icibol nos quatro fioretti.

Temos aqui uma importante diferença na escolha dos vocábulos. Enquanto a leitura de Atena/Ediouro é acessível aos leitores brasileiros mais comuns, o vocábulo escolhido por Vozes restringe a compreensão a leitores mais cultos - ou por conhecerem a língua italiana ou por conhecerem muito bem a língua portuguesa e sua origem latina.

cibo: (do latim cibus)

1. s. m. Ant. comida, alimento (especialmente das aves). 
2. pequena quantidade de alimento ou de qualquer outra coisa.

O vocábulo, como indica o dicionário da língua portuguesa, é antigo. Enquanto o vocábulo italiano $|c i b o|$ é, ainda hoje, totalmente acessível, utilizado no linguajar comum, para nós, |cibol causa estranhamento.

- $\quad \operatorname{messer(e)~(F~I:~Newton,~p.~17,~Garzanti,~p.~03;~F~XVI:~Newton,~p.~37,~Garzanti,~p.~53;~}$

F XXV: Newton, p. 50, Garzanti, p. 70).

1. titolo onorifico attribuito un tempo spec. a cavalieri, notai, giudici e gener. ad altri personaggi.

2. (scherz. iron.) signore.

3. (fam., scherz.) deretano.

Diante deste vocábulo, mais uma vez, temos escolhas lexicais que restringem o alcance original, se as analisamos quanto à simplicidade ou ao rebuscamento dos termos empregados. Novamente, Vozes traz um termo rebuscado em comparação ao empregado por Atena/Ediouro. Eis os vocábulos empregados, respectivamente - |monsior|15; |senhor|16.

\section{monsior - monsenhor - monsieur}

monsenhor (do italiano monsignore): título honorífico, concedido pelo Papa a alguns eclesiásticos e em especial aos seus camareiros.

monsieur (do francês): tratamento correspondente a senhor.

Além do rebuscamento, há certa conotação clerical no vocábulo utilizado por Vozes. A solução de Atena, entretanto, uma vez mais deixa de lado o sabor antigo prometido na introdução. 
- “troppo disprezzato" (F XIII - Newton, p. 33) e "troppo dispregiato" (F XIII Garzanti, p. 44).

As traduções seguem o significado linear dos termos italianos, porém a escolha lexical foi diferente. Atena/Ediouro traz o vocábulo português Idesprezadol17 enquanto Vozes traz Idesprezívell18. Dão-se, através destas escolhas, leituras diferentes nas traduções.

\section{desprezado - particípio passado de desprezar:}

1. ter, sentir testemunhar desprezo a.

2. não fazer caso de; não dar importância a; não prezar.

3. recusar, rejeitar.

4. não levar em conta, não meter em conta, não incluir no cômputo.

5. envergonhar-se de si mesmo; ter-se em má conta.

6. aviltar-se, envilecer-se, rebaixar-se.

"Mas em virtude de ser S. Francisco um homem muito desprezado, e pequeno de corpo..."

(CAPISTRANO, sem data, p. 57 - grifo meu).

Temos aqui que S. Francisco era alvo de desprezo, era desprezado pelos outros.

\section{desprezível:}

1. digno de desprezo, vil, abjeto, miserável, vergonhoso.

"Mas, por ser S. Francisco um homem muito desprezível e pequeno de corpo..." (MORAIS, 1964, p. 30 - grifo meu).

Eis que, na edição Vozes, S. Francisco é desprezível e não desprezado. Sua condição, aqui, é que é digna de desprezo. Enquanto na edição de Atena/Ediouro, S. Francisco é desprezado, não significando que seja digno deste desprezo.

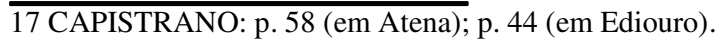
18 MORAIS: p. 30. 
Nos originais temos:

"Ma imperò che santo Francesco era uomo troppo disprezzato e piccolo di corpo..."

(TASCABILI NEWTON, 1993, p.33 - grifo meu).

"Ma però che santo Francesco era uomo troppo dispregiato e piccolo di corpo..."

(GARZANTI, 2003, p.44 - grifo meu).

dispregiato - dispregiare:

1. avere in poco o in nessun pregio.

Sinonimo di disprezzare.

\section{disprezzato - disprezzare:}

1. ritenere qualcuno o qualcosa indegno della propria stima e della propria considerazione.

2. disdegnare.

3. disitimare.

4. avere in poco o nessun conto-detestare.

\section{disprezzabile:}

1. degno di disprezzo;

2. di poco o nessun pregio o importanza.

- $\quad$ bocconi (F XIII - Newton, p.33; Garzanti, p.44)

boccone:

1. quantità di cibo che si può mettere in bocca in una sola volta.

2. piccola quantità di qualcosa.

3. cibo, pasto.

Atena/Ediouro escolhe o vocábulo português |bocados| $\left.\right|^{19 .,}$ Vozes opta por Icôdeas|20.

19 CAPISTRANO: p.58 (em Atena); p. 44 (em Ediouro).

20 MORAIS: p.30. 
bocado:

1. porção de alimento que se leva de uma vez à boca.

2. pedaço, porção.

3. pequena quantidade de qualquer coisa.

côdeas:

1. parte exterior dura; casca, crosta.

2. sujeira solidificada na roupa.

3. crosta de pão, rosca, etc.

Ambas as soluções importam em perdas da totalidade original, já que constituem leituras do original. Porém, no dado exemplo, a solução tradutório Vozes constitui maior perda, pois se dá em vocábulo rebuscado no português, o que comporta a perda da simplicidade do vocábulo italiano; e lcôdeas| não abrange o significado de lbocconil.

- $\quad$ accattare $(F X I I I)$.

\begin{tabular}{|c|c|c|c|}
\hline Newton & Garzanti & Atena/Ediouro & Vozes \\
\hline 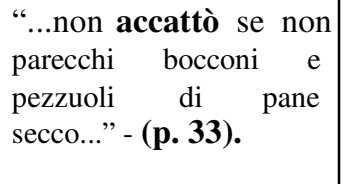 & $\begin{array}{l}\text { “...non accattò se non } \\
\text { parecchi bocconi e } \\
\text { pezzuoli di pane secco." } \\
\text { - (p. } \mathbf{4 4}) \text {. }\end{array}$ & $\begin{array}{l}\text { “...conseguiu apenas } \\
\text { alguns bocados e } \\
\text { pedaços de pão seco..." } \\
-\quad(\text { p. } 57-58 \text { e } 44 \\
\text { respectivamente). }\end{array}$ & $\begin{array}{l}\text { “...só recolheu algumas } \\
\text { côdeas e pedacinhos de } \\
\text { pão sêco." - (p. 30). }\end{array}$ \\
\hline
\end{tabular}

\section{accattare:}

1. cercare di ottenere, chiedendo con insistenza spesso servile; procurarsi; andare in cerca.

2. chiedere in elemosina - sinonimo: mendicare.

3. trovare.

4. ottenere.

\section{conseguir:}

1. alcançar.

2. ter como conseqüência ou resultado. 


\section{recolher:}

1. pôr ao abrigo; guardar, arrecadar.

2. fazer a colheita de.

3. cobrar, receber, arrecadar.

4. reunir, juntar.

5. obter como resultado ou recompensa.

Ambas as traduções perdem o sentido italiano de mendigar, o sentido servil do verbo italiano accattare.

Ainda em F XIII:

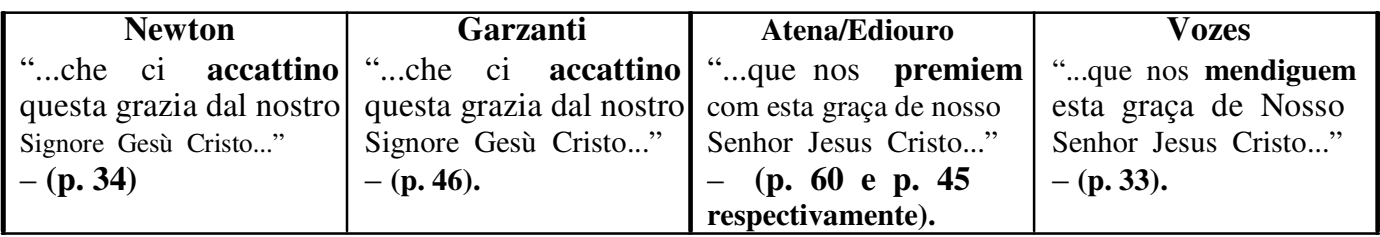

\section{premiar:}

1. dar prêmio ou galardão a; laurear, galardoar.

2. pagar, recompensar, remunerar.

\section{mendigar:}

1. pedir por esmola; esmolar.

2. ganhar ou obter dificilmente.

3. pedir com humildade ou pleitear servilmente.

Novamente o verbo accattare em italiano. Desta vez, porém, temos que a edição da Vozes traduz com o verbo português "mendigar" que cobre parcialmente a faceta anteriormente deixada de lado do verbo italiano. Atena/Ediouro escolhe o verbo "premiar" e perde o matiz servil do verbo - matiz este importante dentro do contexto de $I F$, por se tratar de texto franciscano spirituale. 
- $\quad$ meritare $(F X I I I)$.

\begin{tabular}{|c|c|c|c|}
\hline Newton & Inti & Atena/Ediouro & \\
\hline $\begin{array}{l}\text { “...che per la sua } \\
\text { santissima misericordia } \\
\text { ci conceda di meritare } \\
\text { d'essere veri amatori..." } \\
\text { - (p. 34). }\end{array}$ & $\begin{array}{l}\text { "...che per la sua santa } \\
\text { misericordia ci conceda } \\
\text { di meritare d'essere } \\
\text { veri amatori..." }- \text { (p. } \\
\text { 46). }\end{array}$ & $\begin{array}{l}\text { “...que pela sua } \\
\text { santíssima misericórdia } \\
\text { nos conceda a a } \\
\text { faculdade de sermos } \\
\text { verdadeiros } \\
\text { apreciadores..." } \\
\text { e } \\
\text { respectivamente). }\end{array}$ & $\begin{array}{l}\text { “...que pela sua } \\
\text { santíssima misericórdia } \\
\text { nos conceda o } \\
\text { merecimento } \\
\text { sermos verdadeiros } \\
\text { amadores..." - (p. 33). }\end{array}$ \\
\hline
\end{tabular}

\section{meritare:}

1. essere degno di avere, ottenere, ricevere e sim., in senso positivo o anche negativo.

2. far ottenere, rendere degno, procurare.

Nas traduções Imerecimentol em Vozes e Ifaculdadel em Atena/Ediouro.

\section{merecimento:}

1. qualidade que torna alguém digno de prêmio, estima, apreço, ou de castigo, desprezo, etc.

2. valor, importância.

3. superioridade, excelência.

4. capacidade, habilitação, inteligência, talento, aptidão.

\section{faculdade:}

1. poder natural ou adquirido de fazer alguma coisa.

2. aptidão inata, disposição, tendência, talento, dom.

3. direito, privilégio.

4. liberdade de agir, permissão, consentimento, licença.

5. propriedade, virtude.

A tradução Atena/Ediouro perde a conotação religiosa do original meritare (cf. meriti di Cristo). 
- $\quad$ sirocchie mie uccelli $(F X V I)$.

\begin{tabular}{|c|c|c|c|}
\hline $\begin{array}{l}\text { Newton } \\
\text { "La sustanza della } \\
\text { predica di santo } \\
\text { Francesco fu questa: } \\
\text { 'Sirocchie mie uccelli, } \\
\text { voi siete molto tenute a } \\
\text { Dio vostro creatore..." - } \\
\text { (p. 38). }\end{array}$ & \begin{tabular}{l}
\multicolumn{3}{c}{ Garzanti } \\
"La sustanza della \\
predica di santo \\
Francesco fu questa: \\
'Sirrocchie mie \\
uccelli, voi siete molto \\
tenute a Dio vostro \\
creatore..." - (p. 55).
\end{tabular} & $\begin{array}{l}\text { Atena/Ediouro } \\
\text { “A substância da } \\
\text { prédica de S. Francisco } \\
\text { foi esta: Minhas irmãs } \\
\text { aves, sêde muito } \\
\text { obedientes ao Deus } \\
\text { vosso Criador..." } \\
\text { 69-70 (p. } \\
\text { respectivamente). }\end{array}$ & $\begin{array}{l}\text { Vozes } \\
\text { "A substância da } \\
\text { prédica de S. Francisco } \\
\text { foi esta: Minhas irmãs } \\
\text { aves, deveis estar muito } \\
\text { agradecidas a Deus, } \\
\text { vosso Criador..." - (p. } \\
\text { 38). }\end{array}$ \\
\hline
\end{tabular}

Notar que o original "feminiza" ("sirocchie mie") o masculino ("uccelli"), ponto importante perdido em ambas as traduções. A questão do gênero dentro de $I F$ também deve ser levada em consideração. Este exemplo que aqui trago deixa isso bem claro, afinal, porque sirocchie mie uccelli e não frati miei uccelli? A mistura de gêneros é sim significativa.

Nota-se ainda em Cantico delle Creature (Francisco de Assis, 1224) este contrabalanceamento de gêneros (frate sole, suora luna, frate vento, suora acqua, frate fuoco, suora terra), ainda lembrando a importância da questão de gêneros dentro das novas ordens medievais e do franciscanismo (cf. Santa Clara).

Temos ainda:

sirocchia o serocchia: (lat. sorocula $(m)$, dim. di soror, genit. sororis. V. sorella, suora; av. 1292). S.f. sorella: non aveva costui altri che una s. (MACHIAVELLI).

sororcula, ae $\mathbf{e}^{\text {21: }}$ (dim. de soror) f. irmã querida, irmãzinha (termo de carinho).

Sendo assim, a edição Atena/Ediouro novamente não cumpre o prometido em sua introdução - em que Leoni promete a preservação dos arcaísmos.

Além disso, nenhuma das edições preserva a referência ao diminutivo em latim (lembrando que o diminutivo em $I F$ é de essencial importância).

21 Dicionário de Latim-Português. Porto: Porto Editora, 2001. $2^{\text {a }}$ edição. 
- $\quad$ essere tenuto $(F X V I)$.

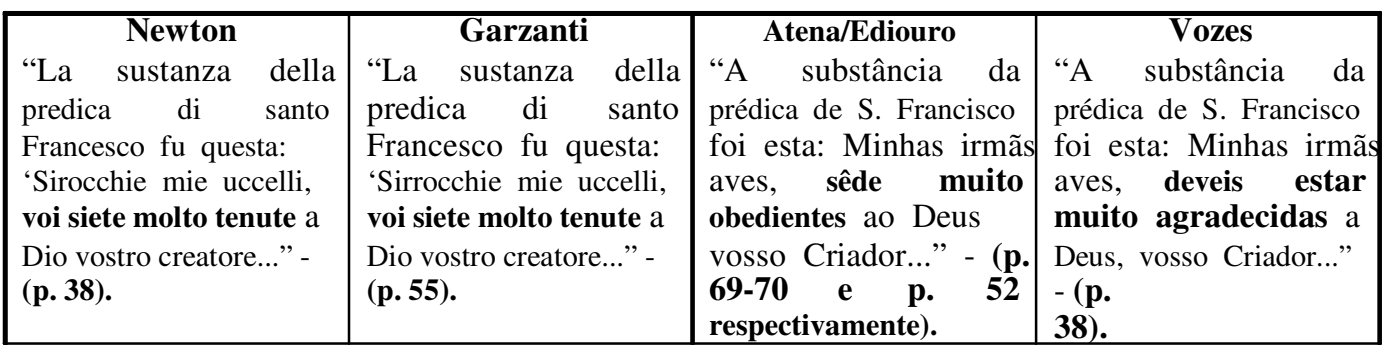

\begin{tabular}{|c|c|c|c|}
\hline Newton & Garzanti & Atena/Ediouro & Vozes \\
\hline $\begin{array}{l}\text { “...ancora gli siete } \\
\text { tenute per lo elemento } \\
\text { dell'aria..." - (p. 38). }\end{array}$ & $\begin{array}{l}\text { "Ancora gli siete } \\
\text { tenute per lo elemento } \\
\text { dell' aria..." - (p. 55). }\end{array}$ & $\begin{array}{ll}\text { “...ainda lhe sois } & \text { solis } \\
\text { devedoras } & \text { pelo } \\
\text { elemento ar..." } & \text { (p. } \mathbf{7 0} \\
\text { e } \quad \text { p. } & \mathbf{5 2} \\
\text { respectivamente). } & \end{array}$ & $\begin{array}{l}\text { "...ainda mais lhe } \\
\text { deveis estar gratas } \\
\text { pelo elemento ar..." } \\
\text { (p. 39). }\end{array}$ \\
\hline
\end{tabular}

essere tenuto: essere tenuto a - (seguito spec. da un inf.), essere obligato, in dovere: $i$ candidati sono tenuti a presentarsi entro le otto.

estar agradecido: agradecer - 1. mostrar-se grato por; 2. demonstrar, manifestar gratidão; 3. retribuir, recompensar.

ser obediente: obedecer - 1. sujeitar-se à vontade de; 2. estar sob a autoridade de; estar sujeito; prestar vassalagem.

O original enfatiza a gratidão; a tradução Atena/Ediouro enfatiza o dever.

- $\quad$ gonfaloniere ( $F X V I-$ Newton, p. 39; Garzanti, p. 56).

Zingarelli Maggiore: (ant. Fr. Gonfalonier; av. 1292)

1. chi porta il gonfalone - bandiera delle antiche milizie; insegna degli antichi comuni.

2. magistrato dei comuni medievali, dapprima con specifiche funzioni e, in seguito, capo del governo civile; rappresentante.

Em Vozes temos Igonfaloneirol22 e em Atena/Ediouro lcondutorl23.

22 MORAIS: p. 39. 
No dicionário da língua portuguesa pesquisado:

\section{gonfaloneiro:}

1. aquele que levava o gonfalão; porta-bandeira.

2. magistrado municipal de certas repúblicas italianas da Idade Média.

Nesta escolha lexical, mais uma vez, temos a simplificação do vocábulo italiano por parte de Atena/Ediouro; a edição Vozes mantém - com sua escolha - a carga de época contida no texto original.

- $\quad$ compieta $(F X V I I)$

\begin{tabular}{|c|c|c|c|}
\hline Newton & Garzanti & Atena/Ediouro & Vozes \\
\hline $\begin{array}{l}\text { “...e la sera, detta } \\
\text { Compieta, s'andò..." } \\
\text { (p. 39). }\end{array}$ & $\begin{array}{l}\text { "E la sera, detta } \\
\text { compieta, s'andò a } \\
\text { dormire..." - }-(\text { p. 57). }\end{array}$ & $\begin{array}{l}\text { “... e à noite, depois das } \\
\text { últimas horas } \\
\text { canônicas, foi deitar- } \\
\text { se..." - (p. } 73 \text { e p. } \mathbf{5 3} \\
\text { respectivamente). }\end{array}$ & $\begin{array}{l}\text { “..e de tarde, ditas } \\
\text { completas, } \\
\text { dormir..." - (p. 40). }\end{array}$ \\
\hline
\end{tabular}

A paráfrase explicativa aparece novamente na tradução das editoras Atena e Ediouro. O termo usado em italiano lcompietal é traduzido pela edição Vozes pelo termo lcompletasl; já Atena/Ediouro não opta pelo termo lcompletasl, mas sim por explicar este termo "últimas horas canônicas". Escolha já antes citada em FXXVIII, na tradução de Atena/Ediouro da hora canônica nona (cf. p.28).

- $\quad$ celluzza (F XVII - Newton, p. 39; Garzanti, p. 57).

Zingarelli:dim. di cella

Cella

1. camera dei frati e suore nel convento.

2. stanza di segregazione in stabilimenti di pena, collegi, accademie militari e sim.

3. (archeol.) parte interna e centrale del tempio antico col simulacro del dio.

4. vano ristretto e di piccole dimensioni adibito a usi particolari. 
“celluzza: 'l'uso frequente dei diminutivi pare voglia sfumare le cose di umiltà per renderle più armoniche a quelle anime.”' [GARZANTI; p. 57].

Novamente encontramos diferença nas escolhas lexicais das traduções em questão:

Atena/Ediouro - |pequena célula|24 e Vozes - |cova|25.

\section{célula:}

1. Biol. Desus. cavidade cheia de ar, delimitada por paredes, encontrada no súber.

2. Biol. Unidade estrutural básica dos seres vivos...

3. Anat. Pequeno interstício no tecido esponjoso dos ossos, ou de outros tecidos.

4. Aer. Conjunto de asas de um aparelho mais pesado que o ar.

5. Fís. Num espaço de fase, região limitada e definida pelas coordenadas das partículas do sistema que estão no interior de intervalos dados.

6. Mús Concr. Motivo melódico ou rítmico que pode aparecer isolado ou fazer parte de uma contextura temática.

7. Mús. Conjunto sem repetição nem evolução que não apresenta os caracteres definidos da nota complexa.

cova:

1. abertura na terra; escavação; buraco.

2. abertura que se faz na terra para plantar um vegetal ou lançar uma semente.

3. buraco onde se escondem certos animais; toca.

4. sepultura.

5. caverna, antro.

Aqui a análise se detém. Fica claro que o uso do vocábulo |celluzal é um diminutivo inferimos tanto pela nota dada pela editora Garzanti quanto pela definição dada pelo dicionário da língua italiana. O que não fica claro é a tradução do vocábulo lcellal dada pelas edições brasileiras.

Atena/Ediouro traduz como lpequena célulal, sendo a referência do vocábulo português |célulal biológica, musical, aeronáutica. A edição Vozes - |coval - parece trazer, ao 
menos à primeira vista, uma referência de morte, sepultura. Porém, o vocábulo original não possui nenhuma das duas referências semânticas, sendo muito mais próximo do campo semântico construção humana, religiosa.

Nota-se que na edição Atena/Ediouro manteve-se alguma referência ao diminutivo (questão esta importante já levantada anteriormente) - lpequenal; já na edição Vozes não. Destaco, mais uma vez, a dificuldade da tradução dos vocábulos diminutivos italianos (celletta, cellina, celluzza).

- $\quad$ campoletti $(F X V I I)$ / in campo, per letto $(F X V I I)$.

As traduções são completamente diferentes uma da outra; enquanto em Vozes temos "dois em cada leito", em Atena/Ediouro temos "tapeçarias":

\begin{tabular}{|c|c|c|c|}
\hline $\begin{array}{l}\text { Newton } \\
\text { "...e stava in uno luogo, } \\
\text { nel quale i frati per } \\
\text { necessità dormivano in } \\
\text { campoletti." - (p. 39). }\end{array}$ & $\begin{array}{l}\text { Garzanti } \\
\text { “...e stando in uno } \\
\text { luogo piccolo, nel quale } \\
\text { i frati per necessità } \\
\text { dormivano in campo, } \\
\text { per letto...” - (p. 57). }\end{array}$ & \begin{tabular}{l}
\multicolumn{1}{c}{ Atena/Ediouro } \\
“...e se achava num \\
pequeno convento, no \\
qual os Irmãos por \\
necessidade dormiam \\
sôbre tapeçarias.” $-(\mathbf{p}$. \\
$\mathbf{7 3}$ e p. $\mathbf{5 3}$ \\
respectivamente).
\end{tabular} & $\begin{array}{l}\text { Vozes } \\
\text { “...e estava em um } \\
\text { pequeno convento no } \\
\text { qual por necessidade os } \\
\text { frades dormiam dois } \\
\text { em cada leito.” - (p. } \\
\text { 40). }\end{array}$ \\
\hline
\end{tabular}

Há realmente uma diferença entre os originais, mas não de tal proporção atingida pelas traduções. Afinal dormiam no chão ou dividiam cama?

\section{CAMPOLETTO s.m.}

0.1 campoletti.

0.2 Lat. campolectus (cfr. Morini, Fioretti, p. 110, n. 2).

0.3 Fioretti S. Francesco, 1370/90 (tosc.): 1.

0.4 Att. unica nel corpus.

0.5 Locuz. e fras. dormire in campoletti 1.

0.71 Fras. Dormire in campoletti: avere per letto la terra.

0.8 Rossella Mosti 19.09.2006.

1 Fras. Dormire in campoletti: avere per letto la terra. 
[1] Fioretti S. Francesco, 1370/90 (tosc.), cap. 17: Uno fanciullo molto puro

e innocente fu ricevuto all'Ordine, vivendo santo Francesco; e stava in un

luogo piccolo, nel quale i frati per necessità dormivano in campoletti.

Sendo assim, os irmãos não dormiam em camas e nem em tapeçarias, mas no chão. A idéia trazida por Atena/Ediouro, “dormiam sobre tapeçarias" é incabível em um ambiente franciscano spirituale, já que possui uma conotação de riqueza - conotação esta totalmente incoerente com os ideais franciscanos. A tradução Vozes perde completamente o sentido original.

- $\quad$ valente uomo ( $F X V I I-$ Newton, p. 40; Garzanti, p. 58)

Zingarelli Maggiore:

1.che ha molti pregi, doti, capacità.

2. che è molto capace ed esperto nella propria attività, professione; eccelente, provetto.

3. (disus.) efficace, valido, detto spec. di rimedio.

Vozes - |homem de valor|

valor: qualidade de quem tem força; audácia, coragem, valentia, vigor.

Atena/Ediouro - |homem útill

útil:

1. que pode ter algum uso ou serventia.

2. proveitoso, vantajoso. 
- “trovò ... col piè”" $(F X V I I)$ e “co' piedi trovò" $(F X V I I)$.

\begin{tabular}{|c|c|c|c|}
\hline Newton & Garzanti & Atena/Ediouro & Vozes \\
\hline $\begin{array}{l}\text { “...trovò il detto } \\
\text { fanciullo, col piè, } \\
\text { giacere nella via come } \\
\text { morto, e per } \\
\text { compassione sì lo levò } \\
\text { e arrecollosi in braccia } \\
\text { e portollo come fa il } \\
\text { buono pastore alle sue } \\
\text { pecore." - (p. } \mathbf{4 0 )} \text {. }\end{array}$ & $\begin{array}{l}\text { “...co' piedi trovò il } \\
\text { detto fanciullo giacere } \\
\text { nella via come morto, e } \\
\text { per compassione sel } \\
\text { levò in braccio e } \\
\text { riportollo a letto, come } \\
\text { fa il buono pastore la } \\
\text { sua pecora." - (p. 58). }\end{array}$ & $\begin{array}{l}\text { “...encontrou o dito } \\
\text { rapaz que jazia como } \\
\text { morto; e por compaixão } \\
\text { o ergueu, e o recolheu } \\
\text { nos braços, como faz o } \\
\text { bom pastor às suas } \\
\text { ovelhas.” - (p. } 74 \text { e } \\
\text { p.53 respectivamente). }\end{array}$ & $\begin{array}{l}\text { “...tropeçou no corpo } \\
\text { do menino que jazia na } \\
\text { estrada como morto, e } \\
\text { por compaixão } \\
\text { carregou-o nos braços e } \\
\text { colocou-o no leito } \\
\text { como faz o bom pastor } \\
\text { com a sua ovelha." - } \\
\text { (p. 40). }\end{array}$ \\
\hline
\end{tabular}

As escolhas lexicais das traduções em português se dão: Itropeçoul e lencontroul.

\section{tropeçar:}

1.dar com o pé involuntariamente; dar topada; esbarrar.

2. encontrar empecilho ou obstáculo inesperado.

3. incorrer ou cair em erro; não atinar.

4. cair, incorrer.

5. vacilar, hesitar.

\section{encontrar:}

2. deparar com; achar.

3. defrontar-se, deparar com, dar de cara com.

4. dar com, atinar com, descobrir.

5. ir de encontro a, topar, chocar-se com.

6. dar de frente, ir de encontro, chocar.

7. topar por acaso, deparar fortuitamente.

As traduções têm conotação de choque, esbarrão, ao passo que o original é suave, indica somente um leve contato dos pés. 
- $\quad$ fedele / santo ( $F$ XVIII).

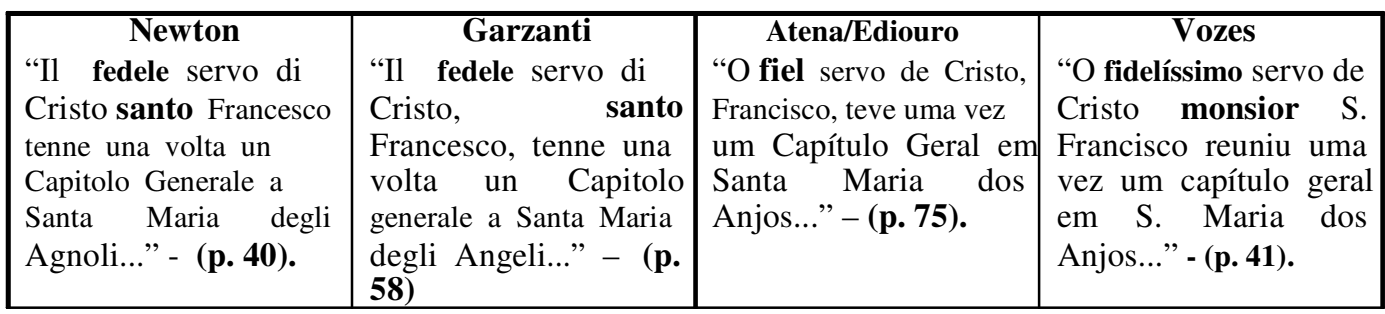

A linguagem da edição Vozes - por suas escolhas lexicais - torna-se bem mais formal se comparada à tradução dada pelas Editoras Atena e Ediouro.

- veramente $(F X V I I I)$

\begin{tabular}{|c|c|c|c|}
\hline $\begin{array}{l}\text { Newton } \\
\text { "Veramente questo sì è } \\
\text { il campo e lo esercito } \\
\text { de' cavalieri di Dio!" - } \\
(\mathbf{p .} \mathbf{4 0 )} \text {. }\end{array}$ & $\begin{array}{l}\text { Garzanti } \\
\text { "Veramente questo è il } \\
\text { campo e lo esercito de' } \\
\text { cavalieri di Dio." - (p. } \\
\mathbf{5 9 ) .}\end{array}$ & $\begin{array}{l}\text { Atena/Ediouro } \\
\text { "Na verdade êste é o } \\
\text { campo, e o exército dos } \\
\text { Cavaleiros de Deus." - } \\
\text { (p. } \mathbf{7 6} \text { e p.55 } \\
\text { respectivamente). }\end{array}$ & $\begin{array}{l}\text { Vozes } \\
\text { "Em verdade, êste é o } \\
\text { campo e o exército dos } \\
\text { cavaleiros de Cristo." - } \\
\text { (p. 41). }\end{array}$ \\
\hline
\end{tabular}

\begin{tabular}{|c|c|c|c|}
\hline Newton & Garzanti & Atena/Ediouro & Vozes \\
\hline $\begin{array}{l}\text { "Veramente Iddio ha } \\
\text { cura speziale di questi } \\
\text { santi poverelli..." - (p. } \\
\text { 42). }\end{array}$ & $\begin{array}{l}\text { "- Veramente Iddio ha } \\
\text { cura speziale di questi } \\
\text { santi poverelli..." }-(\mathbf{p} \\
\text { 62). }\end{array}$ & $\begin{array}{l}\text { "Na verdade, Deus tem } \\
\text { um cuidado especial } \\
\text { com estes santos } \\
\text { pobres..." - (p. } \mathbf{7 8} \text { e p. } \\
\mathbf{5 7} \text { respectivamente). }\end{array}$ & $\begin{array}{lr}\text { "Deveras } & \text { Deus } \\
\text { dispensa } & \text { cuidado } \\
\text { especial a êstes santos } \\
\text { pobrezinhos..." }-\mathbf{( p .} \\
\text { 43). }\end{array}$ \\
\hline
\end{tabular}

veramente: (avverbio di vero)

1. realmente;

2. in frasi interogative, esprime dubbio, meraviglia, incredulità e sim;

3. a dire il vero, però (in funzione limitativa, attenuativa, avversativa); tuttavia.

Atena/Ediouro traduz o vocábulo lveramentel por seu sentido adversativo. Porém, no contexto da obra, o vocábulo original não possui sentido adversativo, mas sim de ênfase da ação.

Na tradução dada pela editora Vozes, temos "Em verdade". Tal expressão em português possui uma conotação altamente religiosa (“Em verdade, em verdade vos digo...”- 
sempre presente nos Evangelhos em traduções portuguesas correntes). O termo original "veramente" não possui esta conotação - em italiano tal conotação evangélica fica com a expressão "In verità, in verità, vi dico...".

- $\quad$ tetti $(F X V I I I)$.

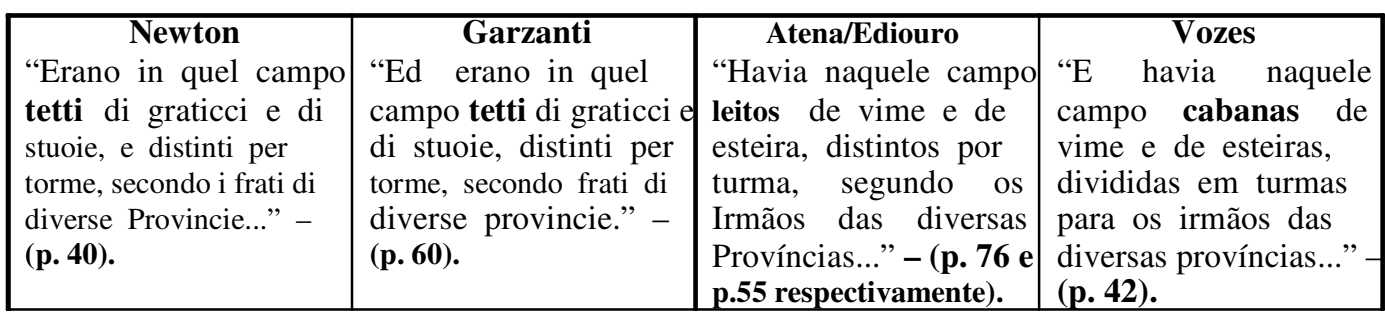

As traduções apresentam soluções bem diferentes para o vocábulo Itettil: |leitos| e |cabanasl.

tetto:

1. copertura a spioventi di un edifício, costituita solitamente da una intelaiatura di travi

o da solai inclinati ricoperti da tegole, embrici, coppi, oppure lamiere ondulate, (...), e sim;

2. casa, dimora, abitazione;

3. copertura, parte superiore.

leito:

1. armação de madeira, ferro, vime, etc que sustenta o enxergão e o colchão da cama;

2. a própria cama;

3. tudo aquilo em que alguém se deita ou se pode deitar como um leito.

cabana: habitação precária e rústica.

A edição Atena/Ediouro escolhe um termo que não corresponde ao original. Um "leito" não é um "tetto". 
Já a Vozes traz o sentido do termo italiano e opta pela tradução consagrada do termo em português - "cabana". Nas referências em língua portuguesa ao "Capítulo das Esteiras" (episódio referido no fioretto em questão), o termo adotado é, quase sempre, "cabanas".

- "piana terra" $(F X V I I I)$.

\begin{tabular}{|c|c|c|c|}
\hline Newton & Garzanti & Atena/Ediouro & Vozes \\
\hline $\begin{array}{l}\text { "I letti loro si era la } \\
\text { piana terra, e chi avea } \\
\text { un poco di paglia..." - } \\
\text { (p.40). }\end{array}$ & $\begin{array}{l}\text { "I letti loro si era la } \\
\text { piana terra, e chi avea } \\
\text { un poco di paglia..." - } \\
\text { (p. 60). }\end{array}$ & $\begin{array}{l}\text { "Os seus leitos eram na } \\
\text { terra limpa, e aí havia } \\
\text { um pouco de palha..."- } \\
\text { (p. 76 e p.55 } \\
\text { respectivamente). }\end{array}$ & $\begin{array}{l}\text { "Os leitos deles eram a } \\
\text { terra nua, e alguns } \\
\text { tinham uma pouca } \\
\text { palha..."-(p. } \mathbf{4 2}) \text {. }\end{array}$ \\
\hline
\end{tabular}

No latim planus: 1. plano, liso, uniforme, de superfície plana, chato. 2. fácil, sem asperezas. 3. claro, manifesto, nítido, evidente.

piana terra: piano di casa a livello del suolo stradale o quasi.

Ambas as traduções optam por expressões que adjetivam terra. Nenhum delas opta pelo termo mais freqüente, corrente e, ao mesmo tempo antigo, em português, que é simplesmente "chão".

- $\quad$ stropiccío (F XVIII - Newton, p.40; Garzanti, p. 59).

Zingarelli maggiore: lo stropicciare continuo; rumore di cosa stropicciata; tramestio, scalpiccio.

Tramestio: movimento continuo e disordinato di persone o cose; il rumore che ne deriva.

Zingarelli minore: stropicciamento continuo; rumore di cosa, spec. piedi, stropicciata.

Soluções para o vocábulo dadas nas traduções brasileiras: Atena/Ediouro - |perturbaçãol; Vozes - Icontendal. 
No Aurélio:

\section{perturbação:}

1. ato ou efeito de perturbar-se.

2. estado de quem se acha perturbado.

3. perplexidade, hesitação, embaraço.

4. transtorno, desordem, confusão, tumulto.

5. tontura, estonteamento, vertigem.

6. alteração das características físicas que se verifica em qualquer ponto de um meio, como, p. ex., uma variação de densidade, de temperatura, dos campos elétrico e magnético.

7. patol. distúrbio no desempenho de uma função física ou psíquica.

\section{contenda:}

1. debate, altercação, disputa, controvérsia.

2. guerra, luta, combate, peleja.

3. fig. esforço para conseguir alguma coisa.

Ambas as traduções perdem a referência semântica do termo original, já que nenhuma das soluções propostas pelas editoras traz, em si, a idéia de barulho provindo da reunião de pessoas - o termo original tem sim uma grande carga semântica de barulho repetido (o sufixo -ío em italiano indica a ação continuada de um verbo)26 e não de luta, como no caso do termo adotado pela Vozes, ou de inquietude dada pelo termo da Atena/Ediouro. Perda da sonoridade.

- $\quad$ lieta $(F X V I I I)$.

\begin{tabular}{|c|c|c|c|}
\hline ton & Zanti & Adelino Capistr & Durval de Morais \\
\hline $\begin{array}{lr}\text { "E tutti quanti } \\
\text { ricevettono } & \text { questo } \\
\text { comandamento } & \text { con } \\
\text { allegro cuore e } & \text { lieta } \\
\text { faccia." - (p. 41). } & \end{array}$ & $\begin{array}{lr}\text { "E tutti quanti } \\
\text { ricevettono questo } \\
\text { comandamento r con } \\
\text { allegro cuore e lieta } \\
\text { faccia." - (p. 61). }\end{array}$ & $\begin{array}{l}\text { "...e todos quantos } \\
\text { receberem esta ordem } \\
\text { com coração alegre e } \\
\text { com rosto satisfeito." - } \\
\text { (p. } 77 \text { e pp. 56-57 } \\
\text { respectivamente). }\end{array}$ & $\begin{array}{l}\text { "E todos êles receberam } \\
\text { êste mandamento com o } \\
\text { coração alegre e com a } \\
\text { face risonha." - }(\mathbf{p . ~ 4 2})\end{array}$ \\
\hline
\end{tabular}

26 Cf. I Pastori de Gabriele D'Annunzio: Ora lungh'esso il litoral cammina / la greggia. Senza mutamento è l'aria. / Il sole imbionda sì la viva lana / che quasi dalla sabbia non divaria. / Isciacquío, calpestío, dolci romori. 
lieta:

1. che sente, che esprime contentezza; felice, beato; allegro, contento, gaio.

2. che riempie di gioia, che dà allegrezza; ameno; gioioso; (raro) prospero.

3. fertile, rigoglioso.

\section{satisfeito:}

1. que se satisfez.

2. saciado, repleto, farto.

3. alegre, prazenteiro, contente.

4. executado, realizado, feito.

\section{risonho:}

1. que ri ou sorri.

2. contente, alegre, satisfeito.

3. agradável, aprazível, deleitoso.

4. cheio de promessas, promissor.

- $\quad$ somieri $(F$ XVIII).

\begin{tabular}{|c|c|c|c|}
\hline Newton & Garzantí & Atena/Ediouro & Vozes \\
\hline $\begin{array}{l}\text { "Ed eccoti subitamente } \\
\text { venire delle predette } \\
\text { terre uomini con } \\
\text { somieri, cavalli, carri, } \\
\text { carichi di pane e di } \\
\text { vino, di fave, di cacio e } \\
\text { d'altre buone cose da } \\
\text { mangiare..." - (p. 41). }\end{array}$ & $\begin{array}{l}\text { "Ed ecco subitamente } \\
\text { venire delle dette terre } \\
\text { uomini con somieri, } \\
\text { cavalli, carri, caricati di } \\
\text { pane e di vino e di fave } \\
\text { e di cacio e d'altre } \\
\text { buone cose da } \\
\text { mangiare..." - (p. 62). }\end{array}$ & $\begin{array}{l}\text { "E viu-se subitamente } \\
\text { chegar das referidas } \\
\text { terras homens com } \\
\text { bêstas de carga, } \\
\text { cavalos, } \text { carros, } \\
\text { carregados de pão e de } \\
\text { vinho, de legumes e de } \\
\text { queijo, e de outras boas } \\
\text { coisas para comer..." - } \\
\text { (p. 78 e p.57 } \\
\text { respectivamente). }\end{array}$ & $\begin{array}{l}\text { "E eis que subitamente } \\
\text { chegam das ditas terras } \\
\text { homens com jumentos, } \\
\text { cavalos, carros } \\
\text { carregados de pães e de } \\
\text { vinhos, favas, queijos e } \\
\text { de outras boas coisas de } \\
\text { comer..." - (p. 43). }\end{array}$ \\
\hline
\end{tabular}

somiere: (lett.) bestia da soma.

A tradução Vozes particulariza um termo geral. 
- $\quad$ fave $(F X V I I I)$.

\begin{tabular}{|c|c|c|c|}
\hline $\begin{array}{l}\text { Newton } \\
\text { "Ed eccoti subitamente } \\
\text { venire delle predette } \\
\text { terre uomini con } \\
\text { somieri, cavalli, carri, } \\
\text { carichi di pane e di } \\
\text { vino, di fave, di cacio e } \\
\text { d'altre buone cose da } \\
\text { mangiare..." - (p. } \mathbf{4 1}) \text {. }\end{array}$ & $\begin{array}{l}\text { Garzanti } \\
\text { "Ed ecco subitamente } \\
\text { venire delle dette terre } \\
\text { uomini con somieri, } \\
\text { cavalli, carri, caricati di } \\
\text { pane e di vino e di fave } \\
\text { e di cacio e d'altre } \\
\text { buone cose da } \\
\text { mangiare..."- (p. 62). }\end{array}$ & $\begin{array}{l}\text { Atena/Ediouro } \\
\text { "E viu-se subitamente } \\
\text { chegar das referidas } \\
\text { terras homens com } \\
\text { bêstas de carga, } \\
\text { cavalos, carros, } \\
\text { carregados de pão e de } \\
\text { vinho, de legumes e de } \\
\text { queijo, e de outras boas } \\
\text { coisas para comer..." - } \\
\text { (p. 78 e p. } \mathbf{5 7} \\
\text { respectivamente). }\end{array}$ & $\begin{array}{l}\text { Vozes } \\
\text { "E eis que subitamente } \\
\text { chegam das ditas terras } \\
\text { homens com jumentos } \\
\text { cavalos, carros } \\
\text { carregados de pães e de } \\
\text { vinhos, favas, queijos e } \\
\text { de outras boas coisas de } \\
\text { comer..." - (p. } \mathbf{4 3}) .\end{array}$ \\
\hline
\end{tabular}

fava:

1. pianta erbacea delle Papilionacee con foglie composte paripennate, fiori di color bianco o violaceo in racemi e legumi scuri contenenti semi verdastri - il seme comestibile di tale pianta.

fava:

1. planta do caule ereto, ornamental, da família das leguminosas, dotada de propriedades medicinais, cujas flores são alvas ou róseas, com máculas negras nas asas, dispostas em racimos axilares, e cujo fruto é vagem viscosa, verde ou preta, comestível, contendo várias sementes - a vagem ou semente dessa e doutras plantas.

\section{legume:}

1. morfologia vegetal - fruto seco, que se abre por duas fendas, característico das leguminosas e constituído de um só carpelo; vagem.

2. bras. hortaliça.

Temos que a tradução de Atena/Ediouro opta por um termo mais geral llegumel. O que, de certa forma, simplifica o texto. 
- $\quad$ ciotole (F XVIII).

\begin{tabular}{|c|c|c|c|}
\hline Newton & Garzanti & Atena/Ediouro & Vozes \\
\hline 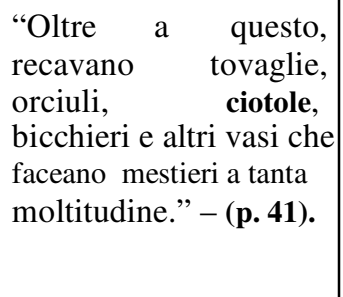 & $\begin{array}{l}\text { "Oltr'a questo, } \\
\text { recavano tovaglie e } \\
\text { orciuoli e bicchieri e } \\
\text { altri vasi, che faceano } \\
\text { mestieri a tanta } \\
\text { moltitudine...." - (p. } \\
\text { 62). }\end{array}$ & $\begin{array}{l}\text { "Além disso, traziam } \\
\text { toalhas, cântaros, } \\
\text { escudelas, copos e } \\
\text { outros vasos, de que } \\
\text { carecia } \quad \text { aquela } \\
\text { multidão..."- (p. } \mathbf{7 8} \text { e } \\
\text { p. } \\
\text { respectivamente). }\end{array}$ & $\begin{array}{l}\text { "Além disso traziam } \\
\text { toalhas, púcaros, } \\
\text { garrafas, copos e } \\
\text { outros vasos de que tal } \\
\text { multidão havia mister." } \\
\text {-(p. 43). }\end{array}$ \\
\hline
\end{tabular}

Em primeiro lugar, é preciso notar a ausência do termo em questão no original dado pela Editora Garzanti.

ciotola:
1. piccolo recipiente a forma di tazza senza manico, in legno, plástica o metallo, destinato spec. a contenere liquidi.
2. ciò che è contenuto in tale recipiente.

garrafa: vaso, comumente de vidro, com gargalo estreito, e destinato a conter líquidos.

escudela: tigela de madeira, pouco funda.

Aqui, ambas as traduções não abarcam inteiramente o significado do vocábulo italiano.

- $\quad$ fare mestieri $(F X V I I I)$.

\begin{tabular}{|c|c|c|c|}
\hline Newton & Garzanti & Atena/Ediouro & Vozes \\
\hline 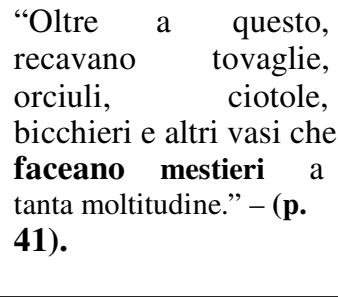 & $\begin{array}{l}\text { "Oltr'a questo, } \\
\text { recavano tovaglie e } \\
\text { orciuoli e bicchieri e } \\
\text { altri vasi, che faceano } \\
\text { mestieri a tanta } \\
\text { moltitudine...." - (p. } \\
\text { 62). }\end{array}$ & $\begin{array}{l}\text { "Além disso, traziam } \\
\text { toalhas, cântaros, } \\
\text { escudelas, copos e } \\
\text { outros vasos, de que } \\
\text { carecia } \\
\text { multidão..." - (p. } \mathbf{7 8} \text { e } \\
\text { p. } \\
\text { respectivamente). }\end{array}$ & $\begin{array}{l}\text { "Além disso traziam } \\
\text { toalhas, púcaros, } \\
\text { garrafas, copos e outros } \\
\text { vasos de que tal } \\
\text { multidão havia } \\
\text { mister." - (p. 43). }\end{array}$ \\
\hline
\end{tabular}


O termo "far mestieri" no século XIV é comum e corresponde a "precisar" - far mestieri: esser necessario. A tradução Vozes do trecho é bem "arcaizante”, a Atena/Ediouro, rebuscada.

- $\quad$ beato $(F X V I I I)$.

\begin{tabular}{|c|c|c|c|}
\hline $\begin{array}{l}\text { Newton } \\
\text { "E beato si riputava chi } \\
\text { più cose potesse } \\
\text { portare, o più } \\
\text { sollecitamente } \\
\text { servire..." - }-(\mathbf{p} . \mathbf{4 1}) .\end{array}$ & \begin{tabular}{l}
\multicolumn{1}{c}{ Garzanti } \\
"E beato si riputava chi \\
più cose poteva recare o \\
più sollecitamente \\
servire..." - (p. 62).
\end{tabular} & \begin{tabular}{l}
\multicolumn{2}{c}{ Atena/Ediouro } \\
“...e bem-aventurado \\
se reputava quem mais \\
coisas pudesse \\
transportar, ou mais \\
solicitamente servir...” \\
- (p. 78 e p.57 \\
respectivamente).
\end{tabular} & $\begin{array}{l}\text { Vozes } \\
\text { "E bendito se } \\
\text { considerava quem mais } \\
\text { coisas podia trazer ou } \\
\text { mais } \quad \text { solicitamente } \\
\text { servia..." - (p. } \mathbf{4 3}) .\end{array}$ \\
\hline
\end{tabular}

O vocábulo italiano lbeatol aqui (e muitas vezes em italiano) não possui necessariamente conotação religiosa. É, ainda hoje, sinônimo de "feliz" (cf. "Beato te, che sei in vacanze").

As traduções: Ibem-aventuradol e lbenditol possuem carga religiosa predominante em português.

- $\quad$ recare / portare $(F X V I I I)$.

\begin{tabular}{|c|c|c|c|}
\hline $\begin{array}{l}\text { Newton } \\
\text { "E beato si riputava chi } \\
\text { più cose potesse } \\
\text { portare, o più } \\
\text { sollecitamente servire, } \\
\text { in tanto ch'eziandio i } \\
\text { cavalieri e li baroni e } \\
\text { altri gentili uomini che } \\
\text { veniano a vedere, con } \\
\text { grande umiltà e } \\
\text { divozione servirono } \\
\text { loro innanzi." - (pp. } \\
\text { 41-42). }\end{array}$ & $\begin{array}{l}\text { Garzanti } \\
\text { "E beato si riputava chi } \\
\text { più cose poteva recare } \\
\text { o più sollecitamente } \\
\text { servire; in tanto che } \\
\text { eziandio i cavalieri e } \\
\text { baroni e altri gentili } \\
\text { uomini che venivano a } \\
\text { vedere, con grande } \\
\text { umiltà e divozione } \\
\text { servivano loro innanzi." } \\
\text { - (p. 62). }\end{array}$ & $\begin{array}{l}\text { Atena/Ediouro } \\
\text { “...e bem-aventurado se } \\
\text { reputava quem mais } \\
\text { coisas pudesse } \\
\text { transportar, ou mais } \\
\text { solicitamente servir; } \\
\text { enquanto que também } \\
\text { os Cavaleiros, e os } \\
\text { Barões, e os outros } \\
\text { gentis homens, que } \\
\text { vinham ver, com grande } \\
\text { humildade e devoção os } \\
\text { serviam em primeiro } \\
\text { lugar.”- (p. } \mathbf{7 8} \text { e p.57 } \\
\text { respectivamente). }\end{array}$ & $\begin{array}{l}\text { Vozes } \\
\text { "E bendito se } \\
\text { considerava quem mais } \\
\text { coisas podia trazer ob } \\
\text { mais solicitamente } \\
\text { servia; de modo que até } \\
\text { os cavaleiros, os barões } \\
\text { e outros gentis homens, } \\
\text { que tinham vindo para } \\
\text { ver, com grande } \\
\text { humildade e devoção } \\
\text { serviam-nos também." } \\
\text { - (p. } \mathbf{4 3}) .\end{array}$ \\
\hline
\end{tabular}

\section{recare:}

1. portare, condurre.

2. avere su di se. 
3. arrecare, causare, produrre.

4. riportare, ridurre.

portare:

1. sostenere su di se un oggetto, un peso e sim. per muoverlo, spostarlo e sim.

2. consegnare, recare, dare.

3. accompagnare, condurre.

4. fare arrivare.

\section{transportar:}

1. conduzir ou levar de um lugar para outro, transpor.

2. extasiar, enlevar, arrebatar.

3. pôr em comunicação, transmitir.

Atena/Ediouro opta por solução erudita, inadequada à simplicidade do texto.

- $\quad$ noia $(F X I X)$.

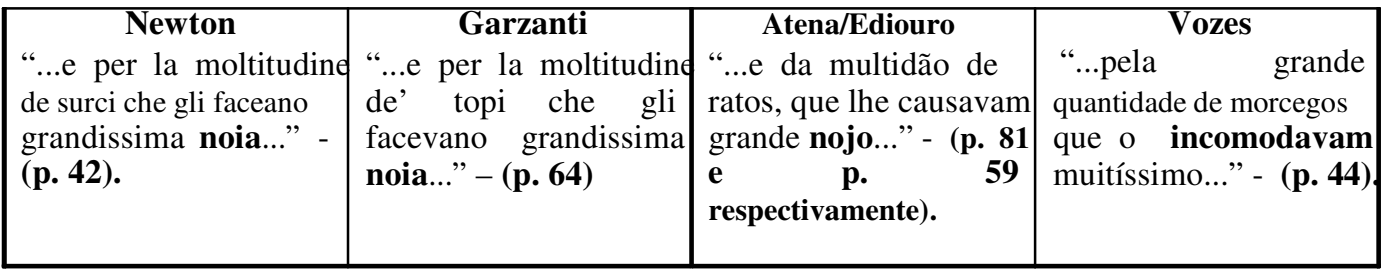

A tradução do termo denuncia, mais uma vez, a incoerência tradutória da edição Atena/Ediouro - ora arcaizante, ora simplificante. Quando traduz o termo Inoial, opta por Inojol - escolha arcaizante que desorienta o leitor, por ser facilmente, hoje, tomada como sinônimo de repugnância.

- dolcezza (F XX-Newton, p. 44; Garzanti, p. 67).

Eis as soluções trazidas em nossas traduções: |doçural- Atena Ediouro e lenleiol Vozes. Novamente aqui temos que a escolha lexical diz muito da leitura da obra pelos 
tradutores, assim como o leitor que se projeta dentro de cada tradução. O vocábulo |dolcezzal

é totalmente acessível a qualquer leitor italiano; enquanto, na tradução da Editora Vozes, temos o vocábulo lenleiol que comporta um leitor mais culto da língua portuguesa.

\section{enleio:}

1. ato ou efeito de enlear-se.

2. laço, enlace, enredo.

3. confusão, perplexidade, dúvida.

4. embaraço, acanhamento, acanho.

5. atrativo irresistível, encanto, deleite, êxtase.

- $\quad \operatorname{duro}(F X X)$.

\begin{tabular}{|c|c|c|c|}
\hline Newton & Garzanti & Atena/Ediouro & Vozes \\
\hline $\begin{array}{l}\text { "E, però, figliuolo, no } \\
\text { ti sai duro portare il } \\
\text { sacco della religione } \\
\text { così fruttuoso..." - (p. } \\
\text { 45). }\end{array}$ & $\begin{array}{l}\text { "E però, figliuolo, nor } \\
\text { ti sia duro di portare } \\
\text { sacco della Religione } \\
\text { così fruttuoso..." - (p. } \\
\text { 68). }\end{array}$ & $\begin{array}{l}\text { "E por isso, meu filho, } \\
\text { que não te seja penoso } \\
\text { carregar o saco da } \\
\text { Religião tão frutuoso..." } \\
\text { - (p. 87 e p. } 62 \\
\text { respectivamente). }\end{array}$ & $\begin{array}{l}\text { "E, portanto, filho, não } \\
\text { te seja molesto trazer o } \\
\text { saial da Ordem tão } \\
\text { frutuoso..." - (p. 47). }\end{array}$ \\
\hline
\end{tabular}

duro:

1. che non si lascia intaccare, scalfire e sim.

2. che cede con difficoltà, che è privo di elasticità.

3. aspro, spiacevole, doloroso.

4. rigido, severo, inflessibile.

5. difficile, arduo.

penoso:

1. que causa pena ou sofrimento.

2. que incomoda.

3. que produz dor; doloroso.

4. difícil, complicado.

\section{molesto:}

1. que causa moléstia ou doença; prejudicial à saúde; nocivo. 
2. que causa aborrecimento; enfadonho, incômodo, molestoso.

3. árduo, penoso, trabalhoso.

4. importuno, impertinente.

5. mau, perverso, maligno.

Os vocábulos escolhidos pelos tradutores privilegiam aspectos particulares do vocábulo italiano, um aspecto da denotação.

- $\quad$ simile vestimento $(F X X)$.

\begin{tabular}{|c|c|c|c|}
\hline & Garzanti & Atena/Ediouro & Vozes \\
\hline $\begin{array}{l}\text { “... però che se col } \\
\text { sacco di santo } \\
\text { Francesco per lo amore } \\
\text { di Cristo tu disprezzerai } \\
\text { il mondo e } \\
\text { mortificherai la carne e } \\
\text { contro al demonio } \\
\text { combatterai } \\
\text { valentemente, tu avrai } \\
\text { insieme con noi simile } \\
\text { vestimento e chiarità di } \\
\text { gloria." - (p. 45). }\end{array}$ & $\begin{array}{l}\text { "... però che, se col } \\
\text { sacco di santo } \\
\text { Francesco per amore di } \\
\text { Cristo tu dispregerai i } \\
\text { mondo e mortificherai } \\
\text { la carne e contra il } \\
\text { demonio combatterai } \\
\text { valentemente, tu avrai } \\
\text { insieme con noi simil } \\
\text { vestimento e chiarità di } \\
\text { gloria." - }(\mathbf{p . 6 8}) \text {. }\end{array}$ & $\begin{array}{l}\text { “... porquanto, se com o } \\
\text { saco de S. Francisco, } \\
\text { pelo amor de Cristo, } \\
\text { desprezares o mundo, e } \\
\text { mortificares a carne, e } \\
\text { contra o Demônio } \\
\text { combateres } \\
\text { valentemente, terás } \\
\text { como nós roupas } \\
\text { iguais, e claridade de } \\
\text { glória." - (p. 87 e p.62 } \\
\text { respectivamente). }\end{array}$ & $\begin{array}{l}\text { “... porque, se com o } \\
\text { saco de S. Francisco } \\
\text { desprezares o mundo e } \\
\text { mortificares a carne, e } \\
\text { contra o demônio } \\
\text { combateres } \\
\text { valentemente, terás } \\
\text { conosco semelhante } \\
\text { veste e claridade de } \\
\text { glória.” - (p. 47). }\end{array}$ \\
\hline
\end{tabular}

- $\quad$ cittadino (F XXI - Newton, p. 45; Garzanti, p. 69).

A edição Vozes traduz o vocábulo lcittadinol por lcitadinol; Atena/Ediouro o traduz por lcidadãol. A escolha da Vozes causa estranhamento para um leitor brasileiro não culto. $\mathrm{O}$ termo lcittadinol não causa estranhamento ao leitor italiano comum.

- $\quad$ giacere $(F X X I)$.

\begin{tabular}{|c|c|c|c|}
\hline Newton & Garzanti & Atena/Ediouro & Vozes \\
\hline "Immantanente che & mmantanente che & "Imediatamente dep & ente após \\
\hline santo Francesco ebbe & esco ebbe & que & S. Fro \\
\hline & il lupo & vel lôbo & cru \\
\hline terribil & terribile $\mathrm{cl}$ & fecl & essou \\
\hline $\begin{array}{l}\text { e ristette di correre; e } \\
\text { fatto il comandamen }\end{array}$ & $\begin{array}{l}\text { bocca, e ristette di } \\
\text { correre. E fatto il }\end{array}$ & $\begin{array}{l}\text { de correr; e } \\
\text { ordem, }\end{array}$ & $\begin{array}{l}\text { de correr; e dada a } \\
\text { ordem, }\end{array}$ \\
\hline
\end{tabular}


\begin{tabular}{|l|l|l|}
\hline venne mansuetamente & comandamento, venne & mansamente, como um
\end{tabular} come agnello, e gittossi mansuetamente come alli piedi di santo uno agnello, e gittossi Francesco a giacere." (p. 45). cordeiro, e lançou-se aos pés de S. Francisco, onde ficou." - (p. 90 e p. Francesco a giacere." (p. 70).

mansamente como um cordeiro e se lança aos pés de S. Francisco como morto." - (p. 48).

\section{giacere:}

1. stare disteso; rimanere esanime al suolo.

2. essere situato; posto.

3. appartenere $a$.

4. stare inerte, inattivo.

5. rimanere abbattuto senza capacità di riprendersi; essere depresso, avvilito.

\section{ficar:}

1. estacionar (em algum lugar); não sair dele; permanecer.

2. estar situado.

3. permanecer em determinada disposição de espírito ou situação.

4. continuar, permanecer.

5. permanecer, conservar-se, demorar-se, deter-se, quedar-se.

\section{morto:}

1. que morreu, defunto, falecido.

2. inerte, insensível.

3. paralisado, entorpecido.

4. extinto, apagado.

5. acabado, terminado, encerrado.

6. desvanecido, esvaecido, desmaiado, desbotado.

7. esquecido, olvidado.

8. sem brilho, sem expressão, inexpressivo.

9. sem atividade, sem vida.

10. muito fatigado, exausto.

A conotação de morte trazida pela tradução Vozes é imprópria do contexto, que fala de preservação da vida do lobo, graças à intervenção de São Francisco.

Atena/Ediouro não explicita a posição de "reverência" do animal perante seu defensor. 
- usare / figliare $(F X X I I)$.

\begin{tabular}{|c|c|c|c|}
\hline Newton & Garzanti & Atena/Ediouro & Vozes \\
\hline $\begin{array}{l}\text { "Ed elleno, usandosi, } \\
\text { cominciarono a fare } \\
\text { uova e figliare dinanzi } \\
\text { alli frati, e così } \\
\text { dimesticamente si } \\
\text { stavano e usavano con } \\
\text { santo Francesco e con } \\
\text { gli altri frati, come se } \\
\text { fussono state galline } \\
\text { sempre nutricate da } \\
\text { loro." - (p. 47). }\end{array}$ & $\begin{array}{l}\text { "Ed elleno usandogli, } \\
\text { cominciarono a fare } \\
\text { uova e figliare innanz } \\
\text { a' frati; e così } \\
\text { dimesticamente si } \\
\text { stavano e usavano con } \\
\text { santo Francesco e con } \\
\text { gli altri frati, come } \\
\text { s'elle fussino state } \\
\text { galline sempre nutricate } \\
\text { da loro." - (p. 74). }\end{array}$ & $\begin{array}{l}\text { "...e elas, aninhando- } \\
\text { se, começaram a botar } \\
\text { ôvo, e a ter filhotes } \\
\text { diante dos Irmãos: "e } \\
\text { tão domesticamente } \\
\text { viviam em relações } \\
\text { com S. Francisco e com } \\
\text { os outros Irmãos", } \\
\text { como se fôssem } \\
\text { galinhas, sempre } \\
\text { alimentadas por êles..." } \\
- \text { (p. } 93 \text { e p. } 66 \\
\text { respectivamente). }\end{array}$ & $\begin{array}{l}\text { "E elas, usando-os, } \\
\text { começaram a pôr ovos e } \\
\text { criar os filhos diante } \\
\text { dos frades: e assim } \\
\text { domesticamente vivian } \\
\text { e tratavam com S. } \\
\text { Francisco e com os } \\
\text { outros frades, como se } \\
\text { fôssem galinhas sempre } \\
\text { criadas por êles." - (p. } \\
\mathbf{5 0 ) .}\end{array}$ \\
\hline
\end{tabular}

No primeiro verbo - "usare" - nota-se o eufemismo sexual presente ainda hoje na linguagem popular. Quando nos transportamos para a tradução Vozes, a conotação sexual perde-se totalmente, chegando o trecho a ficar estranho. Já na tradução dada por

Atena/Ediouro, o verbo "aninhar-se", pouco recupera da conotação sexual original.

Para o segundo verbo:

figliare: generare, partorire, detto spec. di animali; produrre frutti, delle piante e della terra; produrre, causare.

Em Atena/Ediouro temos uma opção mais próxima do mundo animal - "filhotes"; e o verbo "ter" nos dá idéia mais clara de dar à luz. Em Vozes, a palavra "fillhos" parece humanizar os pássaros em questão; o verbo "criar" dá a noção dos cuidados pós parto e não apenas do nascimento.

- $\quad$ grandissima / poverissimo $(F X X I V)$.

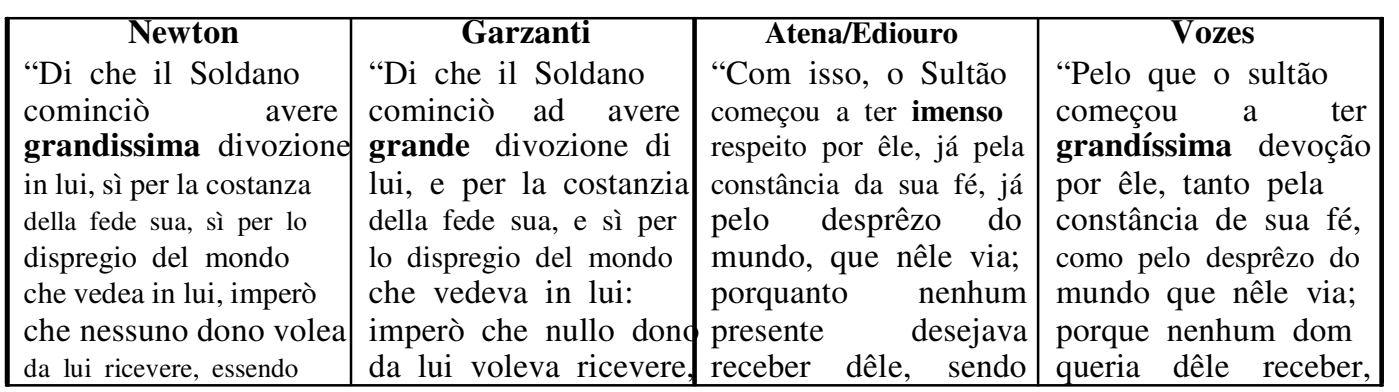




\begin{tabular}{|l|l|l|l|}
\hline poverissimo, e sì & $\begin{array}{l}\text { essendo poverissimo, e } \\
\text { eziandio per lo fervore }\end{array}$ & paupérrimo; e também & sendo pobríssimo; e \\
del martirio, il quale in & fervore del martirio che & pelo ardor, que nêle \\
via." - (p. 97 e p. 68 & também pelo fervor do \\
lui vedeva." - (p. 48). & $\begin{array}{l}\text { in lui vedeva." - (pp. } \\
\text { respectivamente). }\end{array}$ & $\begin{array}{l}\text { - (p. 51). } \\
\text { 76-77). }\end{array}$ \\
\hline
\end{tabular}

Notar aqui as soluções dadas nas traduções para o superlativo.

- fervore del martirio $(F X X I V)$.

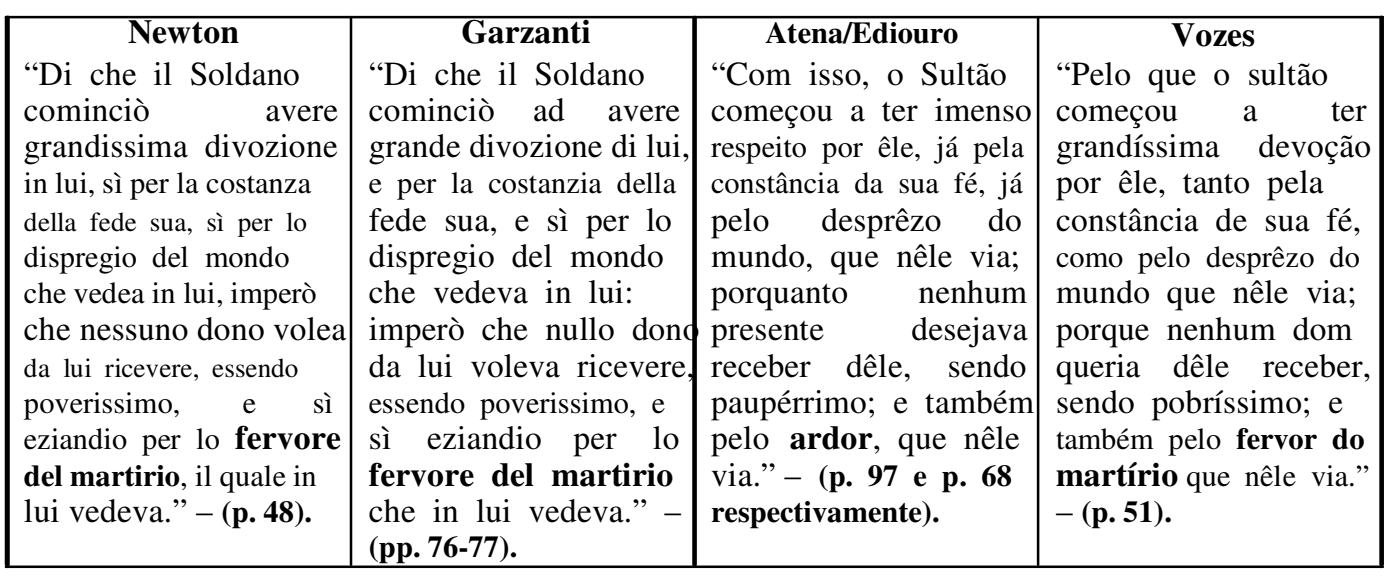

Atena/Ediouro traduz "fervore del martirio" por "ardor", simplesmente.

- "prendette commiato da" (F XXIV).

\begin{tabular}{|c|c|c|c|}
\hline Newton & Garzanti & Atena/Ediouro & Vozes \\
\hline $\begin{array}{l}\text { “...e raunatili tutti } \\
\text { insieme, ritornò al } \\
\text { Soldano e prendette } \\
\text { commiato da lui." - } \\
\text { (p.49). }\end{array}$ & $\begin{array}{l}\text { "E ragunatogli tutti } \\
\text { insieme, ritornò al } \\
\text { Soldano e prese } \\
\text { commiato da lui." - } \\
\text { (pp. } 77-78) \text {. }\end{array}$ & $\begin{array}{l}\text { “... e reunidos todos, foi } \\
\text { até o Sultão, e obteve } \\
\text { dêle licença para } \\
\text { partir." - (p. } 98 \text { e p.69 } \\
\text { respectivamente). }\end{array}$ & $\begin{array}{l}\text { “... e reunindo todos os } \\
\text { seus voltou ao sultão e } \\
\text { despediu-se." - (p. 52). }\end{array}$ \\
\hline
\end{tabular}

prendere commiato da: permesso di allontanarsi, di partire.

SIN. Congedo, licenza, partenza, separazione.

Temos em Durval uma perda significativa da referência do "pedir permissão" // prendere commiato, expressão esta própria para indicar que alguém se despede, respeitosamente, de uma autoridade. 
- $\operatorname{protervo}(F X X V)$.

\begin{tabular}{|c|c|c|c|}
\hline $\begin{array}{l}\text { Newton } \\
\text { “...nel quale era uno } \\
\text { lebbroso si impaziente e } \\
\text { sì incomportabile e } \\
\text { protervo, ch'ogni uno } \\
\text { credeva di certo e così } \\
\text { era, che fusse invasato } \\
\text { dal dimonio..." - (p. } \\
\text { 50). }\end{array}$ & $\begin{array}{l}\text { Garzanti } \\
\text { “...nel quale era uno } \\
\text { lebbroso sì impaziente } \\
\text { sì incomportabile e } \\
\text { protervo, che ognuno } \\
\text { credea, e così era di } \\
\text { certo, che fosse } \\
\text { invasato dal dimonio...” } \\
\text { - (p. 79). }\end{array}$ & $\begin{array}{l}\text { Atena/Ediouro } \\
\text { “...no qual havia um } \\
\text { leproso tão impaciente, } \\
\text { e tão intolerável e } \\
\text { protervo que todo o } \\
\text { mundo julgava, e assim } \\
\text { era, que estivesse com o } \\
\text { Demônio no corpo...” - } \\
\text { (p. 101). }\end{array}$ & $\begin{array}{l}\text { Vozes } \\
\text { “...no qual havia um } \\
\text { leproso tão impaciente } \\
\text { e insuportável e } \\
\text { arrogante que cada um } \\
\text { acreditava certamente, e } \\
\text { assim o era, estar } \\
\text { possuído do demônio.' } \\
\text {-(p. 53) }\end{array}$ \\
\hline
\end{tabular}

Desta vez, a edição Vozes opta por um vocábulo mais comum e a da Atena/Ediouro por um mais rebuscado.

- $\quad$ Borgo Santo Sipolcro $(F X X V I)$.

\begin{tabular}{|c|c|c|c|}
\hline Newton & Garzanti & Atena/Ediouro & Vozes \\
\hline $\begin{array}{l}\text { "Santo Francesco andò } \\
\text { una volta per lo diserto } \\
\text { del Borgo a Santo } \\
\text { Sipolcro, e passando } \\
\text { per uno castello che si } \\
\text { chiama c Monte } \\
\text { Casale..." - (p. 51). }\end{array}$ & $\begin{array}{l}\text { "Santo Francesco andò } \\
\text { una volta per lo } \\
\text { distretto del Borgo a } \\
\text { San Sipolcro, e } \\
\text { passando per uno } \\
\text { castello che si chiamava } \\
\text { Monte Casale..." - (p. } \\
\text { 82). }\end{array}$ & $\begin{array}{l}\text { "S. Francisco, uma } \\
\text { vez, se dirigia pelo } \\
\text { deserto de Borgo a S. } \\
\text { Sepulcro, e passando } \\
\text { por um castelo, que se } \\
\text { chama Monte Casale..." } \\
\text { - (p. 105 e p. } \mathbf{7 3} \\
\text { respectivamente). }\end{array}$ & $\begin{array}{l}\text { "S. Francisco foi uma } \\
\text { vez pelo deserto do } \\
\text { burgo de santo } \\
\text { Sepulcro, e passando } \\
\text { por um castelo que se } \\
\text { chama Monte Casal..." - } \\
\text { (p. 56). }\end{array}$ \\
\hline
\end{tabular}

Sansepolcro (antigamente Borgo a Santo Sipolcro) é um comune na província de Arezzo. A fundação do centro histórico remonta ao século $X$; segundo a tradição local foi obra de Arcano e Egídio, dois peregrinos que, retornando da terra santa, ali fundaram uma comunidade monástica. Ao redor do monastério desenvolveu-se, sucessivamente, o núcleo do centro histórico que alcançou sua fisionomia atual no início do século XIV.

A tradução Vozes deixa a desejar no que se refere à menção a este comune italiano. Pois é nome de referência é Borgo a Santo Sipolcro; quando traduz por "burgo de Santo Sepulcro" a menção particular a este comune se perde. 
- $\quad$ soleva $(F X X V I)$.

\begin{tabular}{|c|c|c|c|}
\hline Newton & & & \\
\hline $\begin{array}{l}\text { "...che per nessuno } \\
\text { modo egli potea } \\
\text { resistere al sonno e } \\
\text { veghiare come soleva." } \\
\text { - (p. 53). }\end{array}$ & $\begin{array}{l}\text { “...che per veruno modo } \\
\text { poteva resistere al } \\
\text { sonno e vegghiare come } \\
\text { e' soleva." - (p. 86). }\end{array}$ & $\begin{array}{l}\text { "...que de modo algum } \\
\text { podia resistir ao sono, e } \\
\text { velar } \\
\text { costumava." } \\
\text { e } \quad \text { (p. } \mathbf{1 0 8} \\
\text { respectivamente). }\end{array}$ & $\begin{array}{l}\text { “...que por maneira } \\
\text { nenhuma podia resistir } \\
\text { ao sono e vigiar como } \\
\text { soía." - (p. 59). }\end{array}$ \\
\hline
\end{tabular}

A edição Vozes traduz por Isoíal e Atena/Ediouro por Icostumaval. Aqui a escolha lexical comportou apenas maior formalidade na linguagem da tradução da editora Vozes. Atena/Ediouro, uma vez mais, deixou de lado a proposta arcaizante anunciada por Leoni (cf.

Capítulo $2-2.2$ ).

- convenire $(F X X V I$ e $F L I)$

\section{FXXVI}

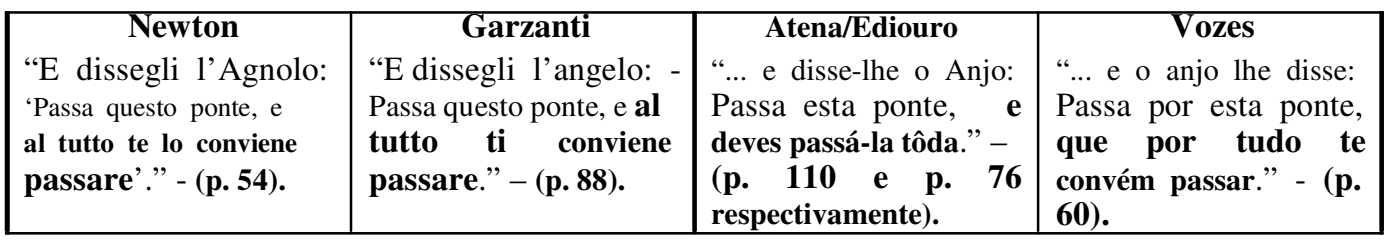

As traduções trazem soluções diferentes, que comportam interpretações distintas. A de Atena/Ediouro nos faz entender que o "frate" deve passar a ponte toda, inteira. Em Vozes, ao frate convém passar por tudo.

$\mathrm{O}$ texto refere-se à ponte. $\mathrm{O}$ frate deve passar a ponte por inteiro e não por tudo.

Temos que em italiano medieval e clássico o verbo convenire indica necessidade e não conveniência (cf. esser convenuto, p. 90). Sendo assim, Vozes erra.

\section{F LI}

\begin{tabular}{|l|l|l|lr|}
\hline \multicolumn{1}{|c|}{ Newton } & \multicolumn{1}{|c|}{ Garzanti } & \multicolumn{2}{c|}{ Atena/Ediouro } & \multicolumn{2}{c|}{ Vozes } \\
“...e che di quella & “...e che di quella & “...e que ele devia & “...e que daquela \\
infermità dovea morire, & infermità dovea morire; & morrer & \multicolumn{1}{c}{ daquela } & enfermidade r devia \\
ma non così di subito, e & ma non così di subito & enfermidade; mas tão & morrer, mas não \\
dopo la morte dovea & dopo la morte dovea & de pronto, e que depois & subitamente, e depois \\
andare a paradiso, però & andare a Paradiso, però & da morte devia ir para o & da morte devia ir ao \\
\hline
\end{tabular}




\begin{tabular}{|c|c|c|c|}
\hline $\begin{array}{l}\text { che convenia un poco } \\
\text { purgarsi in purgatorio." } \\
\text { - (p. 87). }\end{array}$ & $\begin{array}{l}\text { che convenia un po' } \\
\text { purgarsi in purgatorio." } \\
-(\mathbf{p . 1 5 5}) \text {. }\end{array}$ & $\begin{array}{l}\text { Paraíso, embora } \\
\text { devesse limpar-se um } \\
\text { pouco no Purgatório." } \\
\text { (p. 196 e p. 129). }\end{array}$ & $\begin{array}{lc}\text { paraíso, } & \text { porque } \\
\text { convinha um } & \text { pouco } \\
\text { purgar-se } & \text { no } \\
\text { purgatório." }-(\mathbf{p . ~ 1 0 4}) .\end{array}$ \\
\hline
\end{tabular}

Neste exemplo temos Atena/Ediouro temos um equívoco derivado, provavelmente, de um problema de revisão - “...mas tão de pronto...” que em italiano “...ma non così subito...". Verifica-se ser problema de revisão, pois na edição de 1937 da mesma tradução temos “...mas não tão de prompto...” (CAPISTRANO, 1937, p. 177). Porém destaco que o equívoco é publicado por Atena (sem data) e Ediouro (sem data).

Vozes interpreta bem o però che, mas erra em conviene; o irmão, nestefioretto, não iria ao paraíso logo após a morte porque precisava purificar-se.

- $\quad \operatorname{caco}(F X X I X-$ Newton, p. 59; Garzanti, p. 97).

cacare: $=$ cagare $-($ volg $)$ defecare, andare di corpo; eliminare, espellere dal corpo.

Atena/Ediouro - Icagarl 27.

Vozes - lencher de estêrcol28.

Mais uma vez, a escolha lexical da edição Vozes eufemiza, aqui por meio de uma perífrase. Atena/Ediouro usa o termo comum.

- $\quad$ brache / panni di gamba $(F X X X)$.

\begin{tabular}{|c|c|c|c|}
\hline Newton & Garzanti & Atena/Ediouro & Vozes \\
\hline "E allora disse santo & "Allora disse santo & "E então S. Francisco & disse $\mathrm{S}$. \\
\hline $\begin{array}{l}\text { Francesco: 'Però che tu } \\
\text { non hai ubbidito } \\
\text { prestamente, ti } \\
\text { comando per santa } \\
\text { obbidienza che ignudo }\end{array}$ & $\begin{array}{l}\text { Francesco: - Poiché tu } \\
\text { non m'hai ubbidito } \\
\text { prestamente, sì ti } \\
\text { comando per santa } \\
\text { obbedienza che, ignudo }\end{array}$ & $\begin{array}{l}\text { disse: Visto que não } \\
\text { obedeceste } \\
\text { imediatamente, eu te } \\
\text { ordeno por santa } \\
\text { obediência }\end{array}$ & $\begin{array}{l}\text { Francisco: Por não teres } \\
\text { obedecido prontamente, } \\
\text { ordeno-te pela santa } \\
\text { obediência que nun } \\
\text { como nasceste, somente }\end{array}$ \\
\hline $\begin{array}{l}\text { come nascesti, colle } \\
\text { sole brache, tu vada a } \\
\text { Sciesi, ed entri in una }\end{array}$ & $\begin{array}{l}\text { solo co' panni di } \\
\text { gamba, tu vada ad } \\
\text { Ascesi ed entri in una }\end{array}$ & $\begin{array}{l}\text { que, nu } \\
\text { como nasceste, apenas } \\
\text { com os calções, vás a } \\
\text { Assis, e entres numa }\end{array}$ & $\begin{array}{l}\text { de bragas, vás a Assis, } \\
\text { entres numa igreja e } \\
\text { assim nu pregues ao }\end{array}$ \\
\hline
\end{tabular}

27 CAPISTRANO: p. 123 (em Atena); p. 84 (em Ediouro).

28 MORAIS: p. 66. 
predichi al popolo'." (p. predichi al popolo." (p.

60) 100)

Zingarelli maggiore:

braca:

1. (raro) ognuna delle due parti che costituiscono i calzoni.

2. (spec. al pl.) un tempo, ampi calzoni, lunghi fino al ginocchio; (sett.) pantaloni, calzoni.

Aqui também temos uma divergência entre os manuscritos reproduzidos. A edição da Garzanti não traz o termo |brachel, mas sim lpanni di gambal.

As traduções também divergem bastante na escolha lexical. Mais uma vez encontramos um termo muito acessível em Atena/Ediouro e um bem raro Vozes - |calções $\mid$ $\mid$ bragas| respectivamente. O termo utilizado na edição Vozes é bem mais específico e traz também consigo a raridade do termo lbrachel no italiano de hoje.

No dicionário da língua portuguesa:

braga: calção, geralmente curto e largo, que se usava outrora.

- Padre mio reverendo ( $F X X X V I I I$ - Newton, p. 68; Garzanti, p. 116).

Vozes: "Meu venerando padre...”29.

Atena/Ediouro: "Meu venerando Pai..."30.

A tradução do vocábulo italiano Ipadrel pelo português Ipadrel em Vozes torna o trecho bem mais clericalizado que em Atena/Ediouro.

29 MORAIS: p. 79.

30 CAPISTRANO: p. 148 (em Atena); p. 99 (em Ediouro). 
- $\quad$ riprese $(F X L)$.

\begin{tabular}{|c|c|c|c|}
\hline Newton & Garzanti & Atena/Ediouro & Vozes \\
\hline $\begin{array}{l}\text { “...per gli animali non } \\
\text { ragionevoli una volta } \\
\text { tra l'altre, cioè per li } \\
\text { pesci, riprese la } \\
\text { sciocchezza degli } \\
\text { infedeli eretici, a modo } \\
\text { come anticamente nel } \\
\text { vecchio Testamento per } \\
\text { la bocca dell'asina avea } \\
\text { ripresa la ignoranza di } \\
\text { Balaam.” - (p. } \mathbf{7 0}) \text {. }\end{array}$ & $\begin{array}{l}\text { “...per gli animali non } \\
\text { ragionevoli, una volta } \\
\text { fra l'altre, cioè per li } \\
\text { pesci, riprese la } \\
\text { sciocchezza degli } \\
\text { infedeli eretici, a modo } \\
\text { come anticamente nel } \\
\text { Vecchio Testamento } \\
\text { per la bocca dell'asina } \\
\text { avea ripresa la } \\
\text { ignoranza di Balaam." } \\
\text { (pp. 119-120). }\end{array}$ & $\begin{array}{lr}\text { “...pelos } & \text { animais } \\
\text { destituídos } & \text { de } \\
\text { entendimento, } & \text { isto é, } \\
\text { pelos } & \text { peixes, } \\
\text { contrariando } & \text { a } \\
\text { estupidez dos } & \text { infiéis } \\
\text { heréticos, r como } \\
\text { antigamente no Velho } \\
\text { Testamento, pela boca } \\
\text { da Burra contrariara a } \\
\text { ignorância de Balaão.” - } \\
\text { (p. 153 e p. 102 } \\
\text { respectivamente). }\end{array}$ & $\begin{array}{l}\text { “..e pelos animais } \\
\text { irracionais, uma vez } \\
\text { entre outras, isto é, } \\
\text { pelos peixes, } \\
\text { repreendeu a } \\
\text { insensatez dos infiéis } \\
\text { heréticos, como } \\
\text { antigamente no velho } \\
\text { Testamento, pela bôca } \\
\text { da jumenta } \\
\text { repreendera a } \\
\text { ignorância de Balaão." - } \\
\text { (p. 81). }\end{array}$ \\
\hline
\end{tabular}

\section{riprendere:}
1. prendere di nuovo, un'altra volta.
2. prendere indietro ciò che si è dato, prestato, affidato in custodia.
3. rioccupare; riconquistare.
4. recuparare.
5. tornare a colpire.
6. biasimare, ammonire qualcuno.

\section{repreender:}

1. advertir, censurar ou admoestar com energia.

2. argüir, increpar, acusar.

\section{contrariar:}

1. fazer oposição a; estorvar; embaraçar.

2. dizer, fazer ou querer o contrário de; contestar.

3. causar descontentamento a; aborrecer, descontentar, desgostar.

4. estar ou agir em contradição consigo mesmo; contradizer-se.

5. fazer oposição recíproca.

A tradução Atena/Ediouro não abarca o significado de riprendere ao dar como solução tradutória o verbo “contrariar”. Santo Antônio não contraria os fiéis, mas os repreende através de sua pregação aos peixes. 
- sciocchezza $(F X L)$

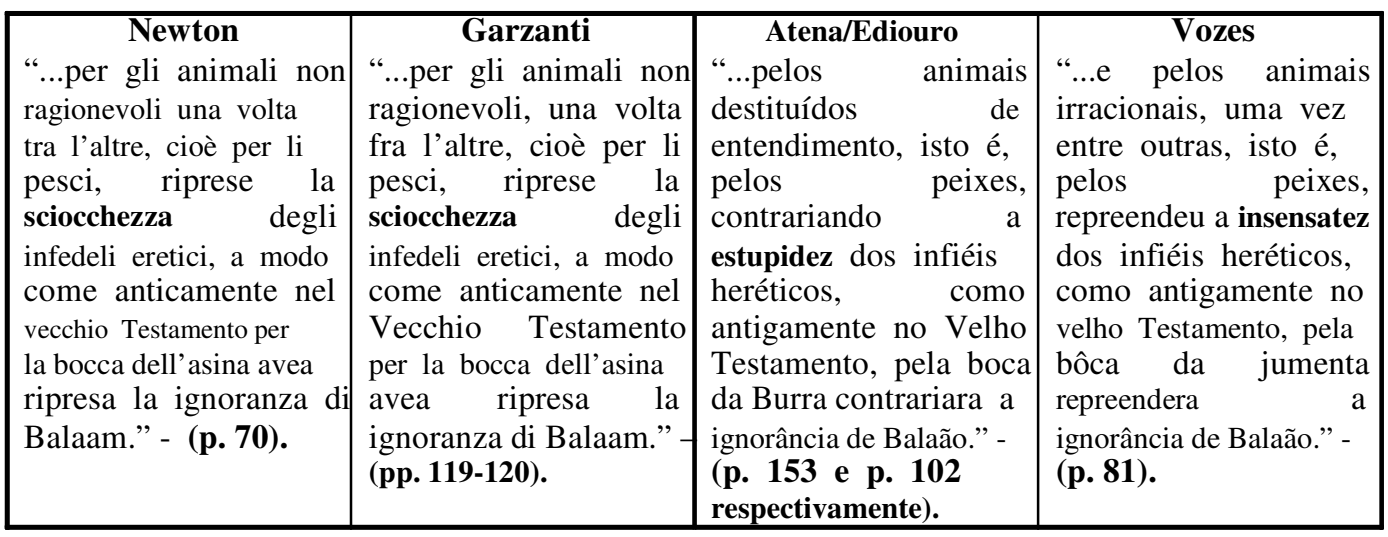

sciocchezza:

1. condizione di chi (o di ciò che) è sciocco - che non ha giudizio, senno, criterio, intelligenza.

2. azione, parola, fatta o detta senza riflettere, senza prudenza.

3. cosa da nulla, inezia.

O vocábulo sciocchezza em italiano é familiar, leve, enquanto as soluções apresentadas nas traduções brasileiras - "estupidez" e "insensatez" - possuem um caráter mais erudito, pesado.

estupidez:

1. qualidade de estúpido; falta de inteligência, de discernimento.

2. palavra, ação, procedimento, que denota estupidez, asneira.

3. Bras. grosseria, descortesia, incivilidade, indelicadeza.

insensatez: qualidade, ato ou dito de insensato.

\section{insensato:}

1. falto de senso ou razão; demente, louco.

2. que não revela bom senso. 
- $\quad$ miei frati $(F X L V)$.

\begin{tabular}{|c|c|c|c|}
\hline $\begin{array}{l}\text { Newton } \\
\text { “...va' a Santo Stefano } \\
\text { dove predica uno de' } \\
\text { miei frati...” - (p. 77). }\end{array}$ & \begin{tabular}{l}
\multicolumn{2}{c}{ Garzanti } \\
“...va' a Santo Stefano \\
ove predica uno de’ \\
miei frati...”- (p. 133).
\end{tabular} & \begin{tabular}{l}
\multicolumn{3}{c}{ Atena/Ediouro } \\
“...vai a santo Estêvão, \\
onde prega um dos \\
meus $\quad$ Irmãos \\
Menores...”- (p. 171 e \\
p. $\quad 113$ \\
respectivamente).
\end{tabular} & $\begin{array}{l}\text { Vozes } \\
\text { “...vai a S. Estêvão, } \\
\text { onde prega um dos } \\
\text { frades menores...”- } \\
\text { (p.91). }\end{array}$ \\
\hline
\end{tabular}

Ambos os tradutores traduzem "miei frati" por "frades menores" ou "Irmãos menores", com perda do tom afetivo e coloquial e ênfase na conotação religiosa.

- $\quad$ montare su $(F X L V)$.

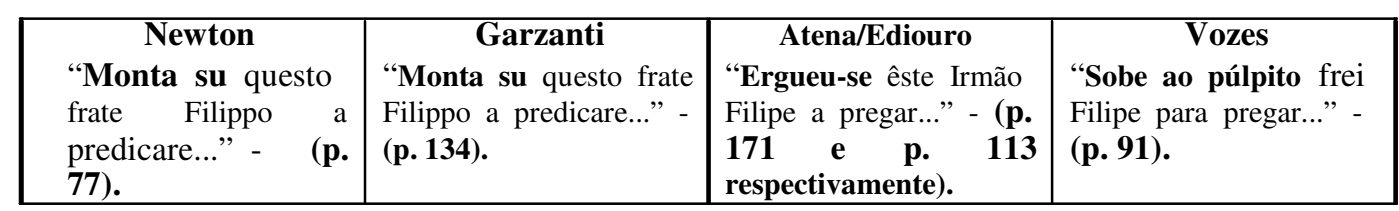

No presente caso, temos duas traduções bem diferentes para um mesmo vocábulo novamente. "Subir ao púlpito" traz uma conotação clerical bem mais formal do que a existente no original.

- $\quad$ assai $(F X L V I)$.

\begin{tabular}{|c|c|c|c|}
\hline Newton & Garzanti & Atena/Ediouro & Vozes \\
\hline $\begin{array}{l}\text { "...e altro istava di } \\
\text { famiglia in uno altro } \\
\text { luogo assai lungi da } \\
\text { lui." - (p. 79). }\end{array}$ & $\begin{array}{l}\text { "...l'altro stava di } \\
\text { famiglia in uno altro } \\
\text { luogo assai di lungi più } \\
\text { da lui." - (p. 138). }\end{array}$ & $\begin{array}{l}\text { “...e o outro estava } \\
\text { servindo em um outro } \\
\text { convento } \quad \text { bastante } \\
\text { retirado dali." - (p. } 177 \\
\text { e } \\
\text { respectivamente). }\end{array}$ & $\begin{array}{l}\text { “...o outro estava de } \\
\text { família em um } \\
\text { convento assaz afastado } \\
\text { dêle." - (p. 94). }\end{array}$ \\
\hline
\end{tabular}

A linguagem da edição Vozes é sempre mais formal, assai em italiano (especialmente italiano medieval) é corrente. 
- $\quad$ la quale allora $(F X L V I)$.

\begin{tabular}{|c|c|c|c|}
\hline Newton & Garzanti & Atena/Ediouro & Vozes \\
\hline $\begin{array}{l}\text { "Come piacque a Dio, } \\
\text { un dì frate Pacifico, } \\
\text { istando in orazione in } \\
\text { luogo solitario, fu ratto } \\
\text { in estasi e vide l'anima } \\
\text { del suo fratello Umile } \\
\text { andare in cielo diritta, } \\
\text { sanza altra ritenzione o } \\
\text { impedimento; la quale } \\
\text { allora si partia del } \\
\text { corpo." - (p. } 79) \text {. }\end{array}$ & $\begin{array}{l}\text { "Come piacque a Dio, } \\
\text { frate Pacifico un dì } \\
\text { standosi in orazione in } \\
\text { luogo solitario, fu rapitd } \\
\text { in estasi, e vide l'anima } \\
\text { del suo fratello frate } \\
\text { Umile andare in cielo } \\
\text { diritta sanza niuna } \\
\text { ritardazione } \\
\text { impedimento; la quale } \\
\text { allora si partiva del } \\
\text { corpo." - (p. 138). }\end{array}$ & $\begin{array}{l}\text { "Como prouve a Deus, } \\
\text { Irmão Pacífico, estando } \\
\text { um dia em oração em } \\
\text { um lugar solitário, foi } \\
\text { arrebatado em êxtase, e } \\
\text { viu a alma do seu } \\
\text { companheiro Irmão } \\
\text { Humilde ir para o Céu } \\
\text { direita, sem outra } \\
\text { retenção } \\
\text { impedimento, a qual } \\
\text { então se retirava do } \\
\text { corpo." - (p. 177 e p. } \\
\text { 117 respectivamente). }\end{array}$ & $\begin{array}{l}\text { "Como prouve a Deus, } \\
\text { frei Pacífico, estando } \\
\text { um dia em oração num } \\
\text { lugar solitário, foi } \\
\text { arrebatado em êxtase e } \\
\text { viu a alma do seu irmão } \\
\text { frei Humilde subir } \\
\text { diretamente ao céu, sem } \\
\text { demora nem } \\
\text { impedimento, na } \\
\text { mesma hora em que } \\
\text { deixava o corpo." - (p. } \\
\text { 94). }\end{array}$ \\
\hline
\end{tabular}

A edição Vozes dá, em sua tradução, uma noção de tempo mais marcada que o original.

- $\quad$ coretto (FXLIX - Newton, p. 84; Garzanti, p. 148)

cuoretto o coretto: (da cuore, perché si portava sul cuore; séc. XIII) strumento di penitenza che si portava sul cuore.

Há uma diferença entre os originais - 'coretto di maglia' em Tascabili Newton e ‘coretto delle maglie' em Garzanti.

Nas traduções, temos a expressão original traduzida por linstrumentos de penitêncial ${ }^{31}$ em Atena/Ediouro e Icilíciol32 em Vozes. Há aqui a opção do primeiro tradutor em adotar uma paráfrase ao invés de um vocábulo específico; talvez para simplificar o texto, o tradutor opte por uma explicação. Já na edição Vozes, faz-se opção pelo vocábulo ao invés de acrescer o texto:

cilício: pequena túnica ou cinto ou cordão, de crina, de lã áspera, às vezes com farpas de madeira, que, por penitência, se trazia vestido diretamente sobre a pele.

31 CAPISTRANO: p. 187 (em Atena); p. 124 (em Ediouro). 32 MORAIS: pp. 99-100. 
Temos que a edição Vozes opta por não simplificar o texto, mas sim manter uma relativa equivalência de vocábulos, porém em italiano existe a palavra cilicio, mas coretto é um tipo específico de cilicio.

- $\quad$ mondizia $(F X L I X)$.

\begin{tabular}{|c|c|c|c|}
\hline $\begin{array}{l}\text { Newton } \\
\text { “...la quale mantiene la } \\
\text { mondizia del corpo...” } \\
\text { - (p. 84). }\end{array}$ & $\begin{array}{l}\text { Garzanti } \\
\text { “...la quale mantiene la } \\
\text { mondizia del corpo...' } \\
\text { - (p. 148). }\end{array}$ & $\begin{array}{l}\text { Atena/Ediouro } \\
\text { “...a qual mantém a } \\
\text { limpeza do corpo...” } \\
\text { (p. } \mathbf{1 8 7} \text { e p.124 } \\
\text { respectivamente). }\end{array}$ & \begin{tabular}{l}
\multicolumn{2}{c}{ Vozes } \\
“...a qual mantém a \\
mundícia do corpo...' \\
- (p. 99).
\end{tabular} \\
\hline
\end{tabular}

Mais uma vez, encontramos em Vozes uma linguagem bem mais formal e em Atena/Ediouro, ao contrário do prometido por Leoni (cf. Capítulo 2 - 2.2), linguagem modernizada.

- $\quad$ il mondo con li suoi amadori $(F X L I X)$.

\begin{tabular}{|c|c|c|c|}
\hline $\begin{array}{l}\text { Newton } \\
\text { “...pensò di lasciare il } \\
\text { mondo con li suoi } \\
\text { amadori...” - (p. 84). }\end{array}$ & $\begin{array}{l}\text { Garzanti } \\
\text { “...pensò di lasciare il } \\
\text { mondo co' suoi } \\
\text { amatori..." - (p. 148). }\end{array}$ & \begin{tabular}{l}
\multicolumn{2}{c}{ Atena/Ediouro } \\
“...pensou em deixar \\
êste mundo e os que o \\
amavam..." - (p. 187 e \\
p. \\
respectivamente).
\end{tabular} & $\begin{array}{l}\text { Vozes } \\
\text { “...pensou de deixar o } \\
\text { mundo com seus } \\
\text { amadores...” - (p. 100). }\end{array}$ \\
\hline
\end{tabular}

A edição Vozes preserva a preposição "com”. Atena/Ediouro substitui a preposição italiana "com" pela conjunção aditiva portuguesa "e".

O fato do verbo "pensar" vir acompanhado da preposição "de", uso aceitável em português clássico, estrutura traduzida em Vozes, causa estranhamento ao leitor brasileiro atual.

- $\quad$ eccessivo $(F X L I X)$.

\begin{tabular}{|c|c|c|c|}
\hline $\begin{array}{l}\text { Newton } \\
\text { "E singularmente per } \\
\text { eccessivo modo uma } \\
\text { volta accese il suo }\end{array}$ & $\begin{array}{l}\text { Garzanti } \\
\text { "E singularmente per } \\
\text { eccessivo modo una } \\
\text { volta accese il suo }\end{array}$ & $\begin{array}{l}\text { Atena/Ediouro } \\
\text { "E singularmente, por } \\
\text { modo extraordinário, } \\
\text { uma vez a flama do }\end{array}$ & $\begin{array}{c}\text { Vozes } \\
\text { "E singularmente uma } \\
\text { vez por modo excessivo } \\
\text { inflamou o seu coração }\end{array}$ \\
\hline
\end{tabular}




\begin{tabular}{|c|c|c|c|}
\hline $\begin{array}{l}\text { cuore la fiamma del } \\
\text { divino amore..." - (p. } \\
\text { 84). }\end{array}$ & $\begin{array}{l}\text { cuore la fiamma del } \\
\text { divino amore..." - } \\
\text { 149). }\end{array}$ & $\begin{array}{l}\text { amor divino acendeu o } \\
\text { seu coração..." - (p. } \mathbf{1 8 8} \\
\text { e } \quad \text { p. } \quad \mathbf{1 2 5}\end{array}$ & $\begin{array}{l}\text { a chama do amor } \\
\text { divino..." - (p. 100). }\end{array}$ \\
\hline
\end{tabular}

eccessivo:

1. che eccede, oltrepassa il limite, la misura.

2. sommo, sovrumano.

3. (poet.) singolare.

A editora Vozes opta por lexcessivol, que em linguagem atual pode ter conotação negativa (excesso indesejável).

excessivo: que é em excesso, exagerado, demasiado, desmedido.

Atena/Ediouro explora a poética do signo italiano - (significado 3) - optando por lextraordináriol.

letizia $(F X L I X)$.

Vocábulo traduzido por lalegrial33 e por Iletícial34 -

Atena/Ediouro e Vozes respectivamente. E novamente fica clara a distinção entre as traduções. Se o vocábulo lalegrial é de compreensão instantânea para qualquer que seja o leitor brasileiro, o vocábulo letícial não. Temos, seguramente, leitores diferentes pressupostos nas traduções envolvidas.

appena $(F L I)$.

\begin{tabular}{|c|c|c|c|}
\hline $\begin{array}{l}\text { Newton } \\
\text { "E trovandolo si } \\
\text { gravato che appena } \\
\text { potea parlare..." - (p. }\end{array}$ & $\begin{array}{l}\text { Garzanti } \\
\text { "E trovandolo sì } \\
\text { aggravato che appena } \\
\text { potea parlare..." }- \text { (p. }\end{array}$ & $\begin{array}{c}\text { Atena/Ediouro } \\
\text { “...e encontrando-o mal, } \\
\text { que mal podia falar..." } \\
- \text { (p. } 196 \text { e p. } \mathbf{1 2 9}\end{array}$ & $\begin{array}{l}\text { Vozes } \\
\text { “...e encontrando-o tão } \\
\text { grave, que apenas } \\
\text { podia falar.” - (p. 104). }\end{array}$ \\
\hline
\end{tabular}

33 CAPISTRANO: p. 190 (em Atena); p. 126 (em Ediouro).

34 MORAIS: p. 102. 
Mais uma vez, a edição Atena/Ediouro utiliza-se do termo português mais usual e a

da Vozes faz escolha de termo não tão usual.

- $\quad$ bellissimo fanciullo $(F L I)$.

\begin{tabular}{|c|c|c|c|}
\hline Newton & Garzanti & Atena/Ediouro & Vozes \\
\hline $\begin{array}{l}\text { "E allora io apparii a } \\
\text { frate Iacopo della } \\
\text { Massa, laico santo, il } \\
\text { quale serviva messa e } \\
\text { vide l'ostia consegrata, } \\
\text { quando il prete la levò, } \\
\text { convertita e mutata in } \\
\text { forma d'uno fanciullo } \\
\text { vivo bellissimo..." - (p. } \\
\text { 88). }\end{array}$ & $\begin{array}{l}\text { "E allora io appari' a } \\
\text { frate Iacopo della } \\
\text { Massa, laico santo, il } \\
\text { quale serviva messa e } \\
\text { vide l'ostia consecrata, } \\
\text { quando il prete la levò, } \\
\text { convertita e mutata in } \\
\text { forma d'uno bellissimo } \\
\text { fanciullo vivo..." - (p. } \\
\text { 156). }\end{array}$ & $\begin{array}{l}\text { "E então eu apareci a } \\
\text { Irmão Jacó da Massa, } \\
\text { leigo santo; o qual } \\
\text { ajudava à missa e vi a } \\
\text { hóstia na forma de um } \\
\text { belíssimo menino } \\
\text { vivo..." - (p. 197 e p. } \\
130 \text { respectivamente). }\end{array}$ & $\begin{array}{l}\text { "E então eu apareci a } \\
\text { frei Tiago da Massa, } \\
\text { leigo santo, o qual } \\
\text { servia a missa e viu a } \\
\text { hóstia consagrada, } \\
\text { quando o padre a } \\
\text { ergueu, convertida e } \\
\text { mudada na forma de } \\
\text { uma belíssima criança } \\
\text { viva..." - (p. 105). }\end{array}$ \\
\hline
\end{tabular}

Masculino por feminino em Vozes. Importante ressaltar a importância da questão de gêneros dentro do contexto das novas ordens medievais e do franciscanismo. Notar frate e suora no Cantico delle Creature; notar "sirocchie... uccelli” (p. 49).

- $\quad$ piacesse $(F L I)$.

\begin{tabular}{|c|c|c|c|}
\hline Newton & Garzanti & Atena/Ediouro & Vozes \\
\hline $\begin{array}{l}\text { "...frate Iacopo glielo } \\
\text { promise, se piacesse a } \\
\text { Dio." - (p. 88). }\end{array}$ & $\begin{array}{l}\text { "...frate Iacopo glielo } \\
\text { impromise, se piacesse } \\
\text { a Dio" - (p. 155). }\end{array}$ & $\begin{array}{l}\text { “...e Irmão Jacó } \\
\text { prometeu-lhe isso, se } \\
\text { Deus não dispusesse o } \\
\text { contrário." - (p. } 196 \text { e } \\
\text { p. } \\
\text { respectivamente). }\end{array}$ & $\begin{array}{l}\text { “..e Tiago prometeu- } \\
\text { lhe, se fosse da } \\
\text { vontade de Deus." - } \\
\text { (p. 105). }\end{array}$ \\
\hline
\end{tabular}

piacere: desiderare, volere. Se piace a Dio, a Dio piacendo - se Dio vorrà.

Atena/Ediouro traz uma negativa e o verbo ldisporl.

Vozes opta pela manutenção da afirmativa - "se fosse da vontade de Deus".

Nenhuma delas conserva o "valor arcaico" (cf. LEONI): "se prouvesse a Deus", em outra circunstância utilizada como opção por Capistrano nas edições Atena/Ediouro no FXXXVII: 


\begin{tabular}{|c|c|c|c|}
\hline Newton & Garzanti & Atena/Ediouro & Vozes \\
\hline "....imperò che io voglio & “....imperò ch'io voglio & “...porquanto eu desejo & “...porque \\
\hline in prima pregare a Dio & prima pregare Iddio che & primeiro pedir a Deus & primeiramente pedir a \\
\hline che faccia pros & prospero il nos & que faça próspero o & deus que torne próspero \\
\hline nostro cammino, che la & cammino, e che la & nosso caminho: que & nosso caminho; e que a \\
\hline noi pensiamo & noi pensiamo di torre al & conceder a nós, pobres & pensamos de arrancar \\
\hline mondo, piacci & сcıа a Cris & débeis, pela virtude da & ao mundo, seja por \\
\hline di concedere a noi & cedere & sua sant & vontade de Cristo \\
\hline poverelli e deboli, per & poverelli e deboli, per & nobre pre & concedida a nós \\
\hline $\begin{array}{l}\text { la virtu derla sua } \\
\text { santissima passione." - }\end{array}$ & la virtu della & arrancar do & pobrezinhos e débeis \\
\hline & & & $\begin{array}{l}\text { santíssima paixão." - } \\
\text { (p. 78). }\end{array}$ \\
\hline
\end{tabular}

E por ambas as traduções no $F X L V I$ :

\begin{tabular}{|c|c|c|c|}
\hline $\begin{array}{l}\text { Newton } \\
\text { "Come piacque a Dio, } \\
\text { un dì frate Pacifico, } \\
\text { istando in orazione in } \\
\text { luogo solitario, fu ratto } \\
\text { in estasi e vide l'anima } \\
\text { del suo fratello Umile } \\
\text { andare in cielo diritta, } \\
\text { sanza altra ritenzione o } \\
\text { impedimento; la quale } \\
\text { allora si partia del } \\
\text { corpo." - (p. } \mathbf{7 9 )} \text {. }\end{array}$ & $\begin{array}{l}\text { Garzanti } \\
\text { "Come piacque a Dio, } \\
\text { frate Pacifico un dì } \\
\text { standosi in orazione in } \\
\text { luogo solitario, fu rapitd } \\
\text { in estasi, e vide l'anima } \\
\text { del suo fratello frate } \\
\text { Umile andare in cielo } \\
\text { diritta sanza niuna } \\
\text { ritardazione } \\
\text { impedimento; la quale } \\
\text { allora si partiva del } \\
\text { corpo." - (p. 138). }\end{array}$ & $\begin{array}{l}\text { Atena/Ediouro } \\
\text { "Como prouve a Deus, } \\
\text { Irmão Pacífico, estando } \\
\text { um dia em oração em } \\
\text { um lugar solitário, foi } \\
\text { arrebatado em êxtase, e } \\
\text { viu a alma do seu } \\
\text { companheiro Irmão } \\
\text { Humilde ir para o Céu } \\
\text { direita, sem outra } \\
\text { retenção } \\
\text { impedimento, a qual } \\
\text { então se retirava do } \\
\text { corpo." - (p. } \mathbf{1 7 7} \text { e p. } \\
\text { 117 respectivamente). }\end{array}$ & $\begin{array}{l}\text { Vozes } \\
\text { "Como prouve a Deus, } \\
\text { frei Pacífico, estando } \\
\text { um dia em oração num } \\
\text { lugar solitário, foi } \\
\text { arrebatado em êxtase e } \\
\text { viu a alma do seu irmão } \\
\text { frei Humilde subir } \\
\text { diretamente ao céu, sem } \\
\text { demora nem } \\
\text { impedimento, na } \\
\text { mesma hora em que } \\
\text { deixava o corpo."- }-(\mathbf{p} . \\
\text { 94). }\end{array}$ \\
\hline
\end{tabular}

\section{3 "Fidelidade" ma non troppo...}

Aqui se comentam alguns casos em que as traduções podem ter incorrido em equívoco, por diversas razões.

- $\quad$ malagevole (F II - Newton, p. 18; Garzanti, p.08).

\begin{tabular}{|c|c|c|c|c|c|c|}
\hline Newton & Garzantí & \multicolumn{2}{|l|}{ Atena/Ediouro } & \multicolumn{3}{|c|}{ Vozes } \\
\hline "Udendo questo, santo & "Udendo questo, santo & ouvindo, & S. & "Ouvindo & isto & S. \\
\hline
\end{tabular}




\begin{tabular}{|c|c|c|c|}
\hline Francesco si rallegrò in & Francesco si rallegrò in & Francisco se alegrou em & $\begin{array}{l}\text { Francisco alegrou- } \\
\text { se }\end{array}$ \\
\hline $\begin{array}{l}\text { ispirito e disse così: } \\
\text { "Messere Bernardo, } \\
\text { questo che voi dite è } \\
\text { opera sì grande e } \\
\text { malagevole, che di ciò } \\
\text { si vuole richiedere } \\
\text { consiglio al nostro } \\
\text { Signore Gesù Cristo..." }\end{array}$ & $\begin{array}{l}\text { ispirito, e disse così: } \\
\text { Messere Bernardo, } \\
\text { questo che voi dite, è } \\
\text { opera sì grande e } \\
\text { malagevole che di ciò } \\
\text { si vuole richiedere il } \\
\text { consiglio del nostro } \\
\text { Signore Gesù Cristo..." }\end{array}$ & $\begin{array}{l}\text { espírito, e disse assim } \\
\text { Senhor Bernardo, o que } \\
\text { dizes é emprêsa tão } \\
\text { grande, e difícil, que } \\
\text { para tanto devemos } \\
\text { pedir conselhos a Nosso } \\
\text { Senhor Jesus Cristo..." } \\
\text { (p. 17) }\end{array}$ & $\begin{array}{l}\text { em espírito e falou: } \\
\text { Monsior Bernardo, isto } \\
\text { que disseste é coisa tão } \\
\text { grande e maravilhosa } \\
\text { que é preciso pedirmos } \\
\text { conselho a Nosso } \\
\text { Senhor Jesus Cristo..." } \\
\text { (p. 11) }\end{array}$ \\
\hline
\end{tabular}

De acordo com o dicionário da língua italiana - difficile, duro, faticoso.

A edição Atena/Ediouro traduz o vocábulo por ldifícill. Porém, a Vozes traz o vocábulo Imaravilhosal. Impropriedade denotativa em Vozes.

stretto $(F I I)$.

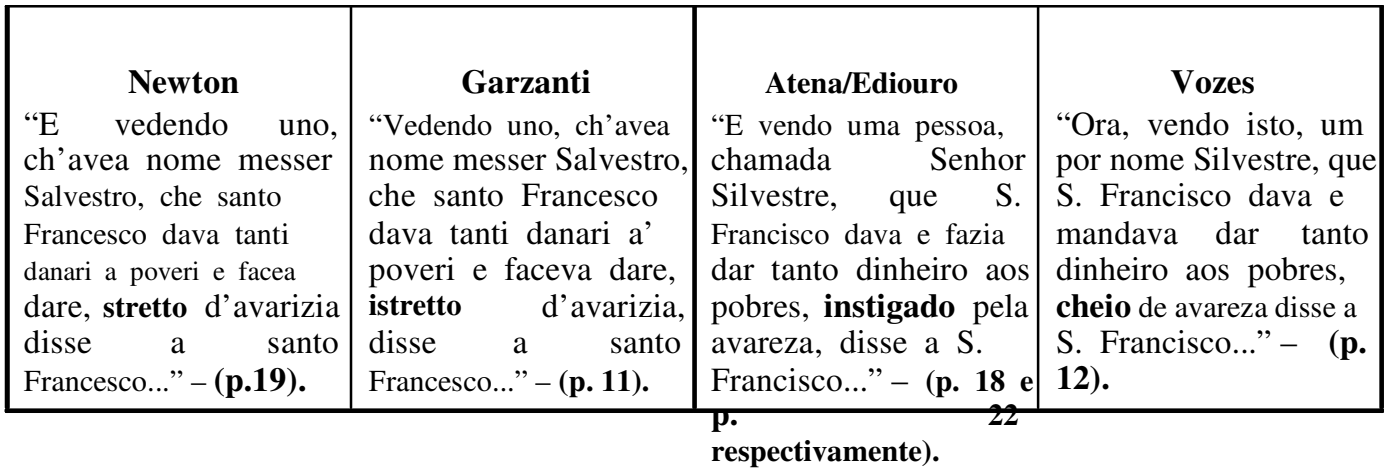

stretto: significato 4 - costretto, spinto: essere s. dalla necessità di fare qualcosa.

instigado: instigar - 1. incitar; estimular. 2. Açular, provocar. 3. Incitar, induzir, mover, estimular, açular, acirrar.

cheio: 1 que contém tudo que sua capacidade comporta; pleno, completo. 2. que abunda em alguma coisa. 4. que excede em alguma qualidade ou propriedade.

Na escolha lexical dada pela Editora Vozes, Silvestro é avarento ao máximo, está repleto de avareza. No texto em italiano, "è stretto d'avarizia", ou seja, é levado pela avareza, 
é instigado pela avareza - não sei se o "frate" excede nesta 'qualidade' ou não, sei apenas que é movido por ela.

- $\quad$ averete / avrete $(F V I)$.

\begin{tabular}{|c|c|c|c|}
\hline Newton & Garzanti & Atena/Ediouro & Vozes \\
\hline $\begin{array}{l}\text { "...lo stato della } \\
\text { Religione ch'io ho } \\
\text { avuto, voi avete, e } \\
\text { questo ch'io ho ora, voi } \\
\text { averete ancora." - (p. } \\
\text { 26). }\end{array}$ & $\begin{array}{l}\text { “..lo stato della } \\
\text { Religione ch'io ho } \\
\text { avuto, voi avete, e } \\
\text { questo ch'io ho ora, voi } \\
\text { avrete ancora." - (p. } \\
\text { 27). }\end{array}$ & $\begin{array}{l}\text { “... o estado de Religião } \\
\text { que eu tive, que } \\
\text { tivestes, e que tenho } \\
\text { agora, tendes ainda...” } \\
- \text { (p. } 37 \text { e p. } 32 \\
\text { respectivamente). }\end{array}$ & $\begin{array}{l}\text { “...no estado de religião } \\
\text { que eu vivi, vós viveis } \\
\text { no em que estou agora } \\
\text { vós ainda estais..."- } \\
\text { (p. 21). }\end{array}$ \\
\hline
\end{tabular}

Nos originais temos o verbo AVERE no futuro - averete e avrete. Porém, nas duas traduções o verbo aparece no presente.

Esta modificação do tempo verbal afeta significativamente o sentido transmitido pelo original. Aqui temos primeiro o verbo no passado ho avuto, em seguido o mesmo verbo no presente avete e ho e, por último, o futuro averete / avrete. No português fica passado - tive, tivestes e vivi - e presente - tenho, viveis, estou e estais. A idéia de futuro simplesmente desaparece.

- $\quad$ insieme $(F X V)$.

\begin{tabular}{|c|c|c|c|}
\hline Newton & Garzanti & Atena/Ediouro & Vozes \\
\hline $\begin{array}{l}\text { "E fatta l'ora di } \\
\text { desinare si pongono a } \\
\text { sedere insieme santo } \\
\text { Francesco e santa } \\
\text { Chiara, e uno delli } \\
\text { compagni di santo } \\
\text { Francesco e la } \\
\text { compagna di santa } \\
\text { Chiara, e poi tutti gli } \\
\text { altri compagni } \\
\text { s'acconciarono alla } \\
\text { mensa umilmente." - } \\
\text { (p. 36). }\end{array}$ & $\begin{array}{l}\text { "E fatta l'ora di } \\
\text { desinare, si pongono } \\
\text { sedere insieme santo } \\
\text { Francesco e santa } \\
\text { Chiara, e uno delli } \\
\text { compagni di santo } \\
\text { Francesco } \\
\text { compagna di santa } \\
\text { Chiara, e poi tutti gli } \\
\text { altri compagni } \\
\text { s'acconciarono alla } \\
\text { mensa umilmente." - } \\
\text { (p. 50). }\end{array}$ & $\begin{array}{l}\text { "E à hora de comer, } \\
\text { sentaram-se juntos, S. } \\
\text { Francisco, e ranta } \\
\text { Clara, e um dos } \\
\text { companheiros de } \mathrm{S} \text {. } \\
\text { Francisco com a } \\
\text { companheira de Santa } \\
\text { Clara, e depois todos os } \\
\text { outros companheiros se } \\
\text { acomodaram à mesa } \\
\text { humildemente." - (p. } \mathbf{6 4} \\
\text { e p. } \\
\text { respectivamente). }\end{array}$ & $\begin{array}{l}\text { "E chegada a hora do } \\
\text { jantar, sentaram-se S. } \\
\text { Francisco e S. Clara, } \\
\text { juntos, e um dos } \\
\text { companheiros de S. } \\
\text { Francisco com a } \\
\text { companheira de S. } \\
\text { Clara, e depois todos os } \\
\text { companheiros de S. } \\
\text { Francisco } \\
\text { acomodaram se } \\
\text { humildemente à mesa." } \\
\text { - (p. 35). }\end{array}$ \\
\hline
\end{tabular}

A tradução dada por Vozes leva - pela simples inversão da ordem sintática - a crer que São Francisco e Santa Clara sentaram-se juntos e os outros depois; isto é, o juntos parece 
fazer referência apenas a São Francisco e Santa Clara, o que não acontece no original e na tradução de Atena/Ediouro.

- $\quad$ tradução de lberel por lbeml - $(F X V I)$.

\begin{tabular}{|c|c|c|c|}
\hline Newton & Garzanti & Atena/Ediouro & Vozes \\
\hline $\begin{array}{l}\text { "...e Iddio vi pasce e } \\
\text { davvi li fiumi e le fonti } \\
\text { per vostro bere..." - (p. } \\
\text { 38). }\end{array}$ & $\begin{array}{l}\text { “...e Iddio vi pasce e } \\
\text { davvi i fiumi e le fonti } \\
\text { per vostro bere..." - } \\
\text { (p. 55). }\end{array}$ & $\begin{array}{l}\text { “...e Deus vos alimenta, } \\
\text { e vos dá os rios, e as } \\
\text { fontes para o vosso } \\
\text { bem..." - (p. } 70 \text { e p.52 } \\
\text { respectivamente). }\end{array}$ & $\begin{array}{l}\text { “...e Deus vos alimenta } \\
\text { e vos dá os rios e as } \\
\text { fontes para beberdes..." } \\
\text { - (p. 39). }\end{array}$ \\
\hline
\end{tabular}

- $\quad$ Capitolo (FXVIII).

\begin{tabular}{|c|c|c|c|}
\hline Nev & & Atena/Ediouro & \\
\hline $\begin{array}{l}\text { “... e udendo la } \\
\text { congregazione } \\
\text { Capitolo che santo } \\
\text { Francesco facea in nel } \\
\text { piano di Santa Maria } \\
\text { degli Agnoli..." - (p. } \\
\text { 40). }\end{array}$ & $\begin{array}{l}\text { "E udendo la } \\
\text { congregazione } \\
\text { Capitolo che santo } \\
\text { Francesco faceva nel } \\
\text { piano di Santa Maria } \\
\text { degli Angeli..." - (p. } \\
\text { 59). }\end{array}$ & $\begin{array}{lr}\text { "E sabendo, pela } \\
\text { congregação, } \\
\text { Capítulo que } & \text { S. } \\
\text { Francisco fazia na } \\
\text { planície de Santa Maria } \\
\text { dos Anjos..." - (p. } \mathbf{7 5} \text { e } \\
\text { p. } \\
\text { respectivamente). }\end{array}$ & $\begin{array}{l}\text { "E sabendo da } \\
\text { reunião do capítulo } \\
\text { que S. Francisco } \\
\text { realizava na planície de } \\
\text { S. Maria dos Anjos..." } \\
\text { (p. 41). }\end{array}$ \\
\hline
\end{tabular}

Atenas/Ediouro traduzem mal - a vírgula muda o sentido - e não se trata de saber "pela", mas de "saber da", como traduz Vozes.

- $\quad$ tutti quanti $(F X V I I I)$.

\begin{tabular}{|c|c|c|c|}
\hline Newton & Garzanti & Atena/Ediouro & Vozes \\
\hline $\begin{array}{l}\text { "E tutti quanti } \\
\text { ricevettono questo } \\
\text { comandamento con } \\
\text { allegro cuore e lieta } \\
\text { faccia." - (p. 41). }\end{array}$ & $\begin{array}{l}\text { "E tutti quanti } \\
\text { ricevettono questo } \\
\text { comandamento con } \\
\text { allegro cuore e lieta } \\
\text { faccia." - (p. 61). }\end{array}$ & $\begin{array}{l}\text { “...e todos quantos } \\
\text { receberem esta ordem } \\
\text { com coração alegre e } \\
\text { com rosto satisfeito." } \\
\text { (p. } \mathbf{7 7} \text { e p. } \mathbf{5 6} \\
\text { respectivamente). }\end{array}$ & $\begin{array}{l}\text { "E todos êles } \\
\text { receberam êste } \\
\text { mandamento com o } \\
\text { coração alegre e com a } \\
\text { face risonha." - (p. 42) }\end{array}$ \\
\hline
\end{tabular}

A edição Atena/Ediouro traduz a expressão tutti quanti por "todos quantos", inaceitável, neste caso, em português. 
tutto:

1. intero, completo.

Con valore rafforz. seguito da 'quanto'.

Se nos originais e na tradução Vozes temos a idéia de que todos receberam totalidade; em Atena/Ediouro temos, talvez, a idéia de 'aqueles que receberem' - portanto, não de totalidade, mas de condição.

- $\quad$ E tutti quanti ricevettono (FXVIII).

\begin{tabular}{|c|c|c|c|}
\hline $\begin{array}{l}\text { Newton } \\
\text { "E quivi disse egli: 'Io } \\
\text { comando, per merito } \\
\text { della santa obbedienza, } \\
\text { che tutti voi che siete } \\
\text { congregati che nessuno } \\
\text { di voi abbia cura né } \\
\text { sollicitudine di veruna } \\
\text { cosa di mangiare o di } \\
\text { bere o di cose } \\
\text { necessarie al copro, ma } \\
\text { solamente intendere a } \\
\text { orare e laudare Iddio; e } \\
\text { tutta la sollecitudine del } \\
\text { corpo vostro lasciate a } \\
\text { lui, imperò ch'egli ha } \\
\text { spezialmente cura di } \\
\text { voi.' E tutti quanti } \\
\text { ricevettono questo } \\
\text { comandamento con } \\
\text { allegro cuore e lieta } \\
\text { faccia." - (p. 41). }\end{array}$ & $\begin{array}{l}\text { Garzanti } \\
\text { "E qui disse egli: - I } \\
\text { comando, per merito } \\
\text { della santa obbedienza, } \\
\text { a tutti voi che siete } \\
\text { congregati qui, che } \\
\text { niuno di voi abbia cura } \\
\text { né sollecitudine di } \\
\text { veruna cosa da } \\
\text { mangiare o da bere, o di } \\
\text { cose necessarie al } \\
\text { corpo, ma solamente } \\
\text { intendete a orare e } \\
\text { lodare Iddio; e tutta la } \\
\text { sollecitudine del corpo } \\
\text { vostro lasciate a Lui, } \\
\text { però ch'Egli ha spezial } \\
\text { cura di voi. - E tutti } \\
\text { quanti ricevettono } \\
\text { questo comandamento } \\
\text { con allegro cuore e } \\
\text { lieta faccia." - (p. 61). }\end{array}$ & 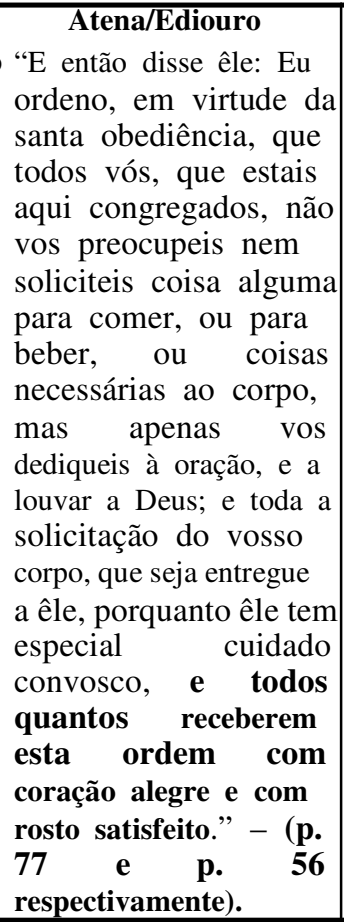 & $\begin{array}{l}\text { Vozes } \\
\text { "E então lhes disse: } \\
\text { Ordeno-vos pelo mérito } \\
\text { da santa obediência, a } \\
\text { todos vós reunidos aqui } \\
\text { que nenhum de vós se } \\
\text { preocupe com o que } \\
\text { tenha de comer ou } \\
\text { beber, ou com as coisas } \\
\text { necessárias ao corpo, } \\
\text { mas aplicai-vos } \\
\text { somente a orar e a } \\
\text { louvar a Deus, e tôda a } \\
\text { solicitude do corpo } \\
\text { deixai a ele, porque ele } \\
\text { terá especial cuidado } \\
\text { convosco. E todos êles } \\
\text { receberam êste } \\
\text { mandamento com o } \\
\text { coração alegre e com a } \\
\text { face risonha." - (p. } \\
\text { 42). }\end{array}$ \\
\hline
\end{tabular}

Em Atena/Ediouro, diferentemente dos originais e da tradução dada por Vozes, o trecho em questão apresenta-se como continuidade da fala de S. Francisco.

- $\quad$ ricevettono $(F X V I I I)$.

No mesmo trecho citado acima, temos um outro caso. 


\begin{tabular}{|c|c|c|c|}
\hline ton & anti & Atena/Ediouro & Vozes \\
\hline $\begin{array}{l}\text { "E tutti quanti } \\
\text { ricevettono questo } \\
\text { comandamento con } \\
\text { allegro cuore e lieta } \\
\text { faccia." - (p. 41). }\end{array}$ & $\begin{array}{l}\text { "E tutti quanti } \\
\text { ricevettono questo } \\
\text { comandamento con } \\
\text { allegro cuore e lieta } \\
\text { faccia." - (p. 61). }\end{array}$ & $\begin{array}{l}\text { “..e todos quantos } \\
\text { receberem esta ordem } \\
\text { com coração alegre e } \\
\text { com rosto satisfeito." - } \\
\text { (p. } \mathbf{7 7} \text { e p. } \mathbf{5 6} \\
\text { respectivamente). }\end{array}$ & $\begin{array}{l}\text { "E todos êles } \\
\text { receberam êste } \\
\text { mandamento com o } \\
\text { coração alegre e com a } \\
\text { face risonha." - (p. 42). }\end{array}$ \\
\hline
\end{tabular}

O verbo "ricevere" no texto original está em sua forma "ricevettono" - passato remoto arcaico (hoje: ricevettero), que indica uma ação em um passado distante. Porém, as edições Atena/Ediouro trazem o verbo em sua tradução no futuro do subjuntivo - ação futura que depende de uma dada condição para acontecer; no caso, a ação expressa neste trecho está ligada ao trecho anterior - que nos originais não estão conectadas desta maneira.

- $\quad$ servirono loro innanzi (FXVIII).

\begin{tabular}{|c|c|c|c|}
\hline $\begin{array}{l}\text { Newton } \\
\text { "E beato si riputava chi } \\
\text { più cose potesse } \\
\text { portare, o più } \\
\text { sollecitamente servire, } \\
\text { in tanto ch'eziandio i } \\
\text { cavalieri e li baroni e } \\
\text { altri gentili uomini che } \\
\text { veniano a vedere, con } \\
\text { grande umiltà e } \\
\text { divozione servirono } \\
\text { loro innanzi." - (pp. } \\
\text { 41-42). }\end{array}$ & $\begin{array}{l}\text { Garzanti } \\
\text { "E beato si riputava chi } \\
\text { più cose poteva recare o } \\
\text { più sollecitamente } \\
\text { servire; in tanto che } \\
\text { eziandio i cavalieri e } \\
\text { baroni e altri gentili } \\
\text { uomini che venivano a } \\
\text { vedere, con grande } \\
\text { umiltà e divozione } \\
\text { servivano } \\
\text { innanzi." - (p. 62). }\end{array}$ & \begin{tabular}{l}
\multicolumn{1}{c|}{ Atena/Ediouro } \\
“...e bem-aventurado se \\
reputava quem mais \\
coisas pudesse \\
transportar, ou mais \\
solicitamente servir; \\
enquanto que também \\
os Cavaleiros, e os \\
Barões, e os outros \\
gentis homens, que \\
vinham ver, com grande \\
humildade devoção os \\
serviam em primeiro \\
lugar.”- (p. 78 e p.57 \\
respectivamente).
\end{tabular} & $\begin{array}{l}\text { Vozes } \\
\text { "E bendito se } \\
\text { considerava quem mais } \\
\text { coisas podia trazer ou } \\
\text { mais solicitamente } \\
\text { servia; de modo que até } \\
\text { os cavaleiros, os barões } \\
\text { e outros gentis homens, } \\
\text { que tinham vindo pard } \\
\text { ver, com grande } \\
\text { humildade e devoção } \\
\text { serviam-nos também." } \\
\text { - (p. } \mathbf{4 3 ) .}\end{array}$ \\
\hline
\end{tabular}

É preciso notar que na tradução Vozes, o trecho traz ao invés da terceira pessoa do plural - loro - a primeira pessoa do plural - nos.

A edição Vozes traduz o termo "innanzi" por "também". No texto, os nobres agem como criados para demonstrarem sua humildade e devoção. Não servem "em primeiro lugar" ou "também" - como dada na tradução de Atena/Ediouro e Vozes respectivamente - mas sim diante de todos, sem se envergonharem do papel subalterno em que se punham. 
- $\quad \operatorname{surci~}(F X I X)$.

\begin{tabular}{|c|c|c|c|}
\hline Newton & Garz: & Atena/Ediouro & Vozes \\
\hline $\begin{array}{l}\text { "...e per la moltitudine } \\
\text { de surci che gli faceano } \\
\text { grandissima noia..." - } \\
\text { (p.42). }\end{array}$ & $\begin{array}{l}\text { “..e per la moltitudin } \\
\text { de' topi che gli } \\
\text { facevano grandissima } \\
\text { noia..." - (p. 64) }\end{array}$ & $\begin{array}{l}\text { "...e da multidão de } \\
\text { ratos, que lhe } \\
\text { causavam grande } \\
\text { nojo..." - (p. } \mathbf{8 1} \text { e p. } \mathbf{5 9} \\
\text { respectivamente). }\end{array}$ & $\begin{array}{lr}\text { “...pela grande } \\
\text { quantidade } \\
\text { morcegos que } \\
\text { incomodavam } \\
\text { muitíssimo..." - (p. 44) }\end{array}$ \\
\hline
\end{tabular}

Temos aqui uma impropriedade denotativa na tradução da Editora

Vozes. Os vocábulos Itopol e Isorciol correspondem ao vocábulo português Iratol e não Imorcegol.

- $\quad$ di me poverello $(F X I X)$.

\begin{tabular}{|c|c|c|c|}
\hline $\begin{array}{l}\text { Newton } \\
\text { “...per lo amore di Dio e } \\
\text { di me poverello...” - } \\
\text { (p. 43). }\end{array}$ & $\begin{array}{l}\text { Garzanti } \\
\text { “...per l'amor di Dio e } \\
\text { di me poverello...”- }(\mathbf{p} \\
\text { 65). }\end{array}$ & $\begin{array}{l}\text { Atena/Ediouro } \\
\text { “...pelo amor de Deus, e } \\
\text { de mim, pobrezinho...? } \\
-\quad(\text { p. } 83 \text { e p. } 60 \\
\text { respectivamente). }\end{array}$ & $\begin{array}{l}\text { Vozes } \\
\text { “...pelo amor de Deus e } \\
\text { do pobrezinho...” - (p. } \\
\text { 45). }\end{array}$ \\
\hline
\end{tabular}

A primeira pessoa dos originais aparece como $3^{\mathrm{a}}$ pessoa na tradução dada pela Vozes.

- $\quad \operatorname{asprezza}(F X X)$.

\begin{tabular}{|c|c|c|c|}
\hline $\begin{array}{l}\text { Newton } \\
\text { “...cominciò ad avere in } \\
\text { tanta abbominazione } \\
\text { l'abito che portava, che } \\
\text { gli parea portare un } \\
\text { sacco vilissimo; avea } \\
\text { orrore delle maniche e } \\
\text { abbominava } \\
\text { cappuccio, e la } \\
\text { lunghezza e la asprezza } \\
\text { gli parea una soma } \\
\text { incomportabile.” - }\end{array}$ & $\begin{array}{l}\text { Garzanti } \\
\text { “...cominciò ad avere in } \\
\text { tanta abbominazione } \\
\text { l'abito che portava, che } \\
\text { gli pareva portare uno } \\
\text { sacco vilissimo. Avea } \\
\text { in orrore le maniche, } \\
\text { abbominava } \\
\text { cappuccio, il } \\
\text { lunghezza e l'asprezza } \\
\text { parevagli una soma } \\
\text { incomportabile." - (p) } \\
\text { 66). }\end{array}$ & $\begin{array}{l}\text { Atena/Ediouro } \\
\text { “...começou a ter em } \\
\text { tanta abominação o } \\
\text { hábito que trazia, que } \\
\text { lhe parecia trazer um } \\
\text { saco vilíssimo; tinha } \\
\text { horror das mangas, } \\
\text { abominava o capuz, e o } \\
\text { comprimento e a } \\
\text { aspereza lhe pareciam } \\
\text { coisas insuportáveis.” - } \\
\text { (p. } \mathbf{8 5} \text { e p. } \mathbf{6 1} \\
\text { respectivamente). }\end{array}$ & $\begin{array}{l}\text { Vozes } \\
\text { “...começou a ter tal } \\
\text { abominação ao hábito } \\
\text { que vestia, que lhe } \\
\text { parecia trazer um saco } \\
\text { vilíssimo; tinha horror } \\
\text { às mangas, abominava } \\
\text { o capuz, e a } \\
\text { comprimento e a } \\
\text { grandeza lhe pareciam } \\
\text { carga insuportável.” - } \\
\text { (p. 46). }\end{array}$ \\
\hline
\end{tabular}

A editora Vozes traduz lasprezzal por lgrandezal. 
- $\quad$ qualunque $(F X X)$.

\begin{tabular}{|c|c|c|c|}
\hline $\begin{array}{l}\text { Newton } \\
\text { "Avea costui già preso } \\
\text { per usanza, secondo che } \\
\text { gli avea insegnato il suo } \\
\text { maestro, qualunque } \\
\text { ora egli passava } \\
\text { dinanzi all'altare del } \\
\text { convento, nel quale si } \\
\text { conservava il corpo di } \\
\text { Cristo, d'inginocchiarsi } \\
\text { con gran riverenza e } \\
\text { trarsi il cappuccio e } \\
\text { colle braccia cancellate } \\
\text { inchinarsi." - (p. 44). }\end{array}$ & $\begin{array}{l}\text { Garzanti } \\
\text { "Avea costui preso già } \\
\text { per usanza, secondo che } \\
\text { gli avea insegnato il suo } \\
\text { maestro, qualunque } \\
\text { ora e' passava dinanzi } \\
\text { all'altare del convento } \\
\text { nel quale si conservava } \\
\text { il Corpo di Cristo, } \\
\text { d'inginocchiarsi con } \\
\text { grande riverenza e trarsi } \\
\text { il cappuccio e colle } \\
\text { braccia cancellate } \\
\text { inchinarsi." - (p. 67). }\end{array}$ & \begin{tabular}{|l|}
\multicolumn{2}{c|}{ Atena/Ediouro } \\
"Tomado pelo costume, \\
segundo o que lhe \\
ensinara o seu mestre, \\
êle passava algumas \\
horas diante do altar do \\
convento; e passando, \\
segundo o r uso, \\
ajoelhou-se e fez \\
reverência." - (p. $\mathbf{8 5}$ e \\
p. \\
respectivamente).
\end{tabular} & $\begin{array}{l}\text { Vozes } \\
\text { "Tomara por costume, } \\
\text { conforme lhe ensinara } \\
\text { seu mestre, tôdas as } \\
\text { vezes que passavam } \\
\text { em frente ao altar do } \\
\text { convento, no qual se } \\
\text { conservava o corpo de } \\
\text { Cristo, ajoelhar-se com } \\
\text { grande reverência e } \\
\text { tirar o capuz e inclinar- } \\
\text { se com os braços em } \\
\text { cruz." - (p. 46). }\end{array}$ \\
\hline
\end{tabular}

A edição da Atena/Ediouro traz "êle passava algumas horas" para o italiano "qualunque ora e' passava".

qualunque: 1. l'uno o l'altro che sai, indifferentemente. 2. ogni.

Isto é, "ogni volta che passava davanti all'altare” e não que ele passasse várias horas diante do altar. Neste caso, a edição da Vozes é mais apropriada.

- $\quad$ orecchi $(F X X I)$.

\begin{tabular}{|c|c|c|c|}
\hline Newton & Garzanti & Atena/Ediouro & Vozes \\
\hline $\begin{array}{l}\text { "...il lupo con atti di } \\
\text { corpo e di coda e di } \\
\text { orecchi e con inchinare } \\
\text { il capo..." - (p. } \mathbf{4 5}) \text {. }\end{array}$ & $\begin{array}{l}\text { "...il lupo con atti di } \\
\text { corpo e di coda e } \\
\text { d'orecchi e con } \\
\text { inchinare di capo..." } \\
\text { (pp. 70-71) }\end{array}$ & $\begin{array}{l}\text { “...o lôbo, com } \\
\text { movimentos de corpo e } \\
\text { de cauda e de olhos, e } \\
\text { com inclinações de } \\
\text { cabeça..." - (p. } 90 \text { e pp. } \\
\text { 63-64 } \\
\text { respectivamente). }\end{array}$ & $\begin{array}{l}\text { "E o lôbo ajoelha-se e } \\
\text { inclina a cabeça, e com } \\
\text { movimentos mansos de } \\
\text { corpo e de cauda e de } \\
\text { orelha..." - (p. 49). }\end{array}$ \\
\hline
\end{tabular}

Na edição Atena/Ediouro traduz-se lorecchil por lolhosl.

- $\quad$ saracini $(F X X I V)$.

\begin{tabular}{|c|c|cc|c|}
\hline Newton & Garzanti & \multicolumn{2}{|c|}{ Atena/Ediouro } & Vozes \\
“Avuta adunque questa & "Avuta adunque questa & "Com uma licença & "Obtida esta licença tão \\
\hline
\end{tabular}




\begin{tabular}{|c|c|c|c|}
\hline $\begin{array}{l}\text { licenza così libera, } \\
\text { santo Francesco mandò } \\
\text { quelli suoi eletti } \\
\text { compagni a due a due } \\
\text { in diverse parti di } \\
\text { Saracini a predicare la } \\
\text { fede di Cristo..." - (p. }\end{array}$ & $\begin{array}{l}\text { Francesco mandò que' } \\
\text { suoi eletti compagni a } \\
\text { due a due, in diverse } \\
\text { parti di Saracini a } \\
\text { predicare la fede di } \\
\text { Cristo..." - (p. } \mathbf{7 7}) \text {. }\end{array}$ & $\begin{array}{l}\text { Francisco mandou } \\
\text { aquêles seus } \\
\text { companheiros, dois a } \\
\text { dois, para diversas } \\
\text { partes de Sarcini a } \\
\text { pregar a Fé de Cristo..." }\end{array}$ & $\begin{array}{l}\text { generosa, S. } \\
\text { Francisco } \\
\text { mandou aquêles seus } \\
\text { eleitos companheiros, } \\
\text { dois a dois, por diversas } \\
\text { terras de sarracenos, a } \\
\text { predicar a fé cristã..." - } \\
\text { (p. 52). }\end{array}$ \\
\hline
\end{tabular}

respectivamente).

A edição Atena/Ediouro traduz o termo como se fosse um lugar.

offendano il prossimo $(F X X V I)$.

\begin{tabular}{|c|c|c|c|}
\hline $\begin{array}{l}\text { Newton } \\
\text { “...e poi li priega da mia } \\
\text { parte che non facciano } \\
\text { più male, ma temano } \\
\text { Iddio e non offendano } \\
\text { il prossimo...” - (p. 52). }\end{array}$ & $\begin{array}{l}\text { Garzanti } \\
\text { "...e poi li priega da mia } \\
\text { parte che non faccino } \\
\text { più male, ma temano } \\
\text { Iddio, e non offendano } \\
\text { il prossimo..." - (p. }\end{array}$ & $\begin{array}{l}\text { Atena/Ediouro } \\
\text { “...em seguida lhes } \\
\text { peças, em meu nome, } \\
\text { que não façam mais } \\
\text { mal, mas temam a } \\
\text { Deus, e não o ofendam }\end{array}$ & $\begin{array}{l}\text { Vozes } \\
\text { “...e depois lhes rogues } \\
\text { de minha parte que não } \\
\text { mais façam o mal, mas } \\
\text { temam a Deus, e não } \\
\text { ofendam o próximo...” }\end{array}$ \\
\hline
\end{tabular}

Nos originais, e na tradução dada por Vozes, quem não pode ser ofendido é o próximo.

Na tradução de Atena/Ediouro, Deus é quem não pode ser ofendido e há o acréscimo do advérbio de tempo "nunca" inexistente nos originais.

ali / alie $(F X X V I)$.

\begin{tabular}{|c|c|c|c|}
\hline \begin{tabular}{l}
\multicolumn{1}{c}{ Newton } \\
“...e pareali, per lo \\
primo e secondo e terzo \\
mettere ali, avere \\
aspettato bene cento \\
cinquanta anni o più." -
\end{tabular} & $\begin{array}{l}\text { Garzanti } \\
\text { "E parevagli, per lo } \\
\text { primo e per lo secondo } \\
\text { e terzo mettere alie, } \\
\text { avere aspettato bene } \\
\text { cento cinquanta anni o }\end{array}$ & $\begin{array}{l}\text { Atena/Ediouro } \\
\text { “...pareceu-lhe, pela } \\
\text { primeira e segunda e } \\
\text { terceira vez que caía } \\
\text { ali, que esperava bem } \\
\text { cento e cinquienta anos, }\end{array}$ & $\begin{array}{l}\text { Vozes } \\
\text { “...e pareceu-lhe que } \\
\text { pelo primeiro e segundo } \\
\text { e terceiro crescimento } \\
\text { de asas, tinha esperado } \\
\text { bem cento e cinqüenta }\end{array}$ \\
\hline
\end{tabular}

ala: (plurale ali oppure alie) - organo che consente il volo a uccelli, pipistrelli e taluni insetti (ma anche a esseri mitologici o fantastici, come l'arpia, l'ippogrifo, gli angeli e $i$ demoni, ecc). 
Nas edições Atena/Ediouro traduz-se o vocábulo italiano lalil pelo advérbio de lugar português lalil.

- $\quad$ fuori che dinnanzi a lui $(F X X I X)$.

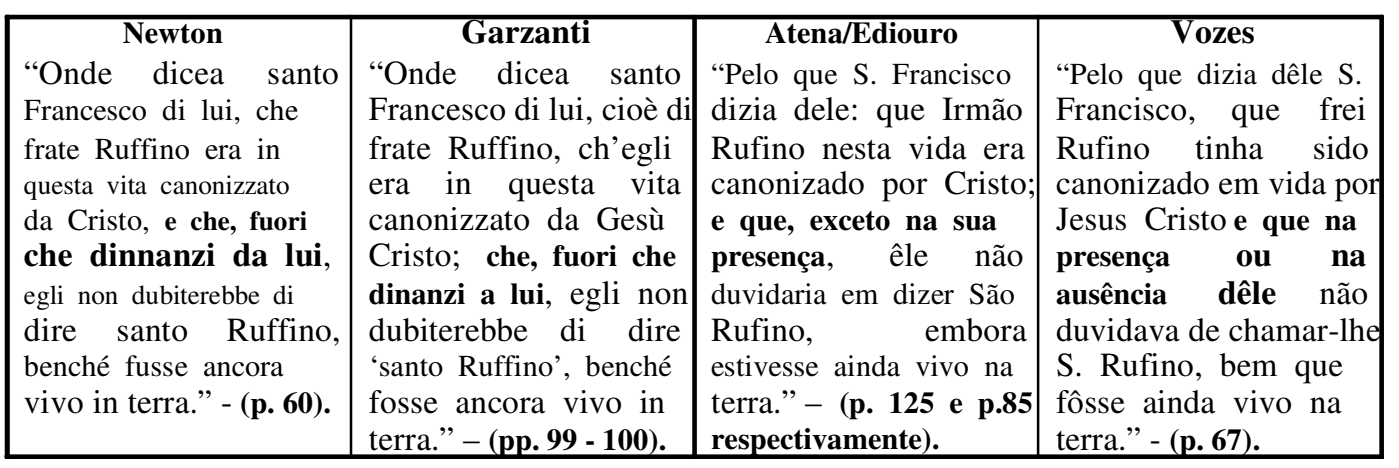

Aqui temos uma diferença bem grande entre as traduções dadas. Em Atena/Ediouro traduz-se o trecho por "exceto na sua presença".

fuori che: eccetto, tranne.

Em Vozes, temos "na presença ou na ausência dele". A edição Vozes parece interpretar o "che" como comparativo.

- $\quad$ elleno $(F$ XXXIII).

\begin{tabular}{|c|c|c|c|}
\hline Newton & Garzanti & Atena/Ediouro & Vozes \\
\hline "In quel tempo & "In quel tempo & "Nesse tempo Sóror & "Naquele tempo vivia \\
\hline dimorava in quel & dimorava in & Ortolana, mãe de Santa & naquele mosteiro sóror \\
\hline monastero & monasterio & Clara, e Sóror Inês, sua & Ortolana, mãe de S. \\
\hline Ortulana madre di santa & Ortolana, madre di & irmã, ambas juntamente & Clara, e sóror Inês, sua \\
\hline Chiara, e suora Agnese & santa Chiara, e suora & com Santa Clara, & om S. \\
\hline sua sirocchia, amendue & Agnese sua sirocchia, & moravam & $\begin{array}{l}\text { Clara, cheias de vir } \\
\text { e de espírito san }\end{array}$ \\
\hline piene di virtù $\mathrm{e}$ & santa Chiara, piene di & virtudes e do Espírito & com muitas outras \\
\hline $\begin{array}{l}\text { di } \text { Spirito } \\
\text { molte altre, e con } \\
\text { sante }\end{array}$ & $\begin{array}{l}\text { virtù e di Spirito Santo, } \\
\text { e con molte altre sante }\end{array}$ & $\begin{array}{l}\text { Santo, além de outras } \\
\text { santas monjas; às quais }\end{array}$ & $\begin{array}{l}\text { santas religiosas. Às } \\
\text { quais mandava } \mathrm{S} \text {. }\end{array}$ \\
\hline monache. Alle quali & monache. Alle quali & S. Francisco mandava & Francisco muitos \\
\hline $\begin{array}{l}\text { mandava di molti } \\
\text { infermi; ed elleno con } \\
\text { le loro orazioni e col }\end{array}$ & $\begin{array}{l}\text { mandava molti infermi; } \\
\text { ed elleno colle loro } \\
\text { orazioni e col segno }\end{array}$ & $\begin{array}{l}\text { elas, com as suas } \\
\text { orações e com o sinal } \\
\text { da Santíssima Cruz, a }\end{array}$ & $\begin{array}{l}\text { suas orações e com o } \\
\text { sinal da santa cruz a } \\
\text { todos restituíam saúde.' }\end{array}$ \\
\hline & & & \\
\hline
\end{tabular}




\begin{tabular}{|c|c|c|c|}
\hline $\begin{array}{l}\text { segno della santissima } \\
\text { croce a tutti rendevano } \\
\text { sanità." - (p. 64). }\end{array}$ & $\begin{array}{l}\text { della croce a tutti } \\
\text { rendeano la sanità." - } \\
\text { (pp. 106-107). }\end{array}$ & $\begin{array}{l}\text { todos davam saúde." }- \\
\begin{array}{lll}\text { (p.136 e } & \text { p. } & 91 \\
\text { respectivamente). }\end{array}\end{array}$ & - (p. 72). \\
\hline
\end{tabular}

Pelo contexto - "alle quali" - fica claro que "elleno" refere-se às irmãs anteriormente citadas. Em Vozes, traduz-se lellenol por lelesl. Em Atena há a perda do valor arcaico de elleno, sem qualquer ganho compensatório.

- $\quad$ gli $(F X X X I V)$.

\begin{tabular}{|c|c|c|c|}
\hline Newton & Garzanti & Atena/Ediouro & Vozes \\
\hline $\begin{array}{l}\text { “...eglino n'ebbono } \\
\text { grandissima malincolia } \\
\text { che frate Egidio non gli } \\
\text { avea parlato parola; e } \\
\text { rammaricandosene, si } \\
\text { gli dissono: 'O frate } \\
\text { Egidio, perché se' tu } \\
\text { tanto villano, che uno } \\
\text { così fatto re, il quale è } \\
\text { venuto di Francia per } \\
\text { vederti e per udire da te } \\
\text { qualche buona parola, e } \\
\text { tu non gli hai parlato } \\
\text { niente?" - (p. 64). }\end{array}$ & $\begin{array}{l}\text { “...eglino n’ebbono } \\
\text { grande malincolia, } \\
\text { perché frate Egidio non } \\
\text { gli avea parlato parola. } \\
\text { E rammaricandosene, sì } \\
\text { gli dissono: - O frate } \\
\text { Egidio, perché se' tu } \\
\text { stato così villano, che a } \\
\text { uno così fatto re, il } \\
\text { quale è venuto di } \\
\text { Francia per vederti e } \\
\text { per udire da te qualche } \\
\text { buona parola, e tu non } \\
\text { hai parlato niente?” - } \\
\text { (p. 108). }\end{array}$ & $\begin{array}{l}\text { “...êles experimentaram } \\
\text { enorme melancolia por } \\
\text { Irmão Egídio não lhes } \\
\text { haver falado nada a } \\
\text { respeito; e queixando- } \\
\text { se, disseram: Ó Irmão } \\
\text { Egídio, por que foste } \\
\text { tão vilão, que não } \\
\text { falaste nada a um tão } \\
\text { santo Rei, o qual veio } \\
\text { de França para ver-te, e } \\
\text { para ouvir de ti alguma } \\
\text { palavra boa?” - (p. 138 } \\
\text { e p. 92). }\end{array}$ & $\begin{array}{l}\text { “...houveram êles } \\
\text { grande melancolia } \\
\text { porque frei Egídio não } \\
\text { lhe tinha dito palavra; e } \\
\text { lamentando-se lhe } \\
\text { disseram: Ó frei Egídio, } \\
\text { por que fôste tão vilão; } \\
\text { que a um tão grande rei, } \\
\text { o qual veio de França } \\
\text { para ver-te e para ouvir } \\
\text { alguma boa palavra não } \\
\text { disseste nada?" - (p. } \\
\text { 72-74). }\end{array}$ \\
\hline
\end{tabular}

Impropriedade em Atena/Ediouro - em que se traduz "gli" pelo plural em português "lhes". Porém, no contexto, fica claro que o pronome se refere ao rei da França, portanto singular "lhe" como se traduziu em Vozes. Lamenta-se o fato de Egídio não ter falado nada ao rei da França e não o fato de não ter comunicado a presença do rei da França aos outros, como nos fazem entender as editoras Atena/Ediouro em sua tradução.

- $\quad$ incaricati / caricati $(F X X X V I)$

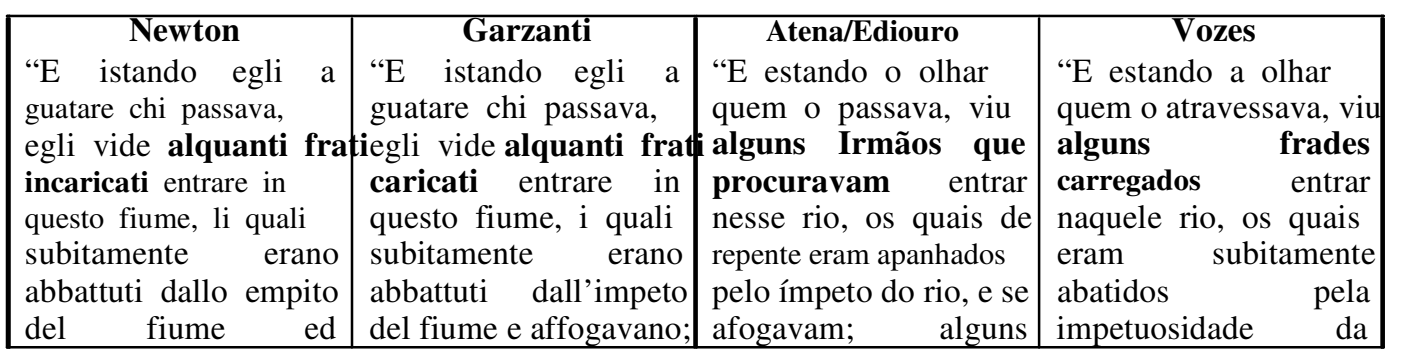




\begin{tabular}{|c|c|c|c|}
\hline $\begin{array}{l}\text { affogavano, alquanti } \\
\text { altri s'andavano insino } \\
\text { al terzo del fiume, } \\
\text { alquanti insino al } \\
\text { mezzo del fiume, } \\
\text { alquanti insino appresso } \\
\text { alla proda; i quali tutti, } \\
\text { per l'empito del fiume e } \\
\text { per li pesi che } \\
\text { portavano addosso, } \\
\text { finalmente cadevano e } \\
\text { annegavano." - (p. 65). }\end{array}$ & $\begin{array}{l}\text { alquanti altri andavano } \\
\text { infino a terzo, alquant } \\
\text { infino a mezzo il fiume, } \\
\text { alquanti infino presso } \\
\text { all'altra proda, i quali } \\
\text { tutti, per l'impeto del } \\
\text { fiume e pe' pesi che } \\
\text { portavano addosso, } \\
\text { finalmente cadevano e } \\
\text { annegavano." - } \text { - (p. } \\
\text { 110). }\end{array}$ & $\begin{array}{l}\text { outros irmãos iam até a } \\
\text { têrça parte do rio; } \\
\text { outros até a metade; } \\
\text { outros até junto da } \\
\text { margem; e todos, pelo } \\
\text { ímpeto do rio, e pelo } \\
\text { pêso } \\
\text { transportavam, que } \\
\text { finalmente caíam e se } \\
\text { afogavam." - (p. } \mathbf{1 4 1} \text { e } \\
\text { p. } \\
\text { respectivamente). }\end{array}$ & $\begin{array}{l}\text { corrente e se afogavam, } \\
\text { outros iam até um têrço, } \\
\text { outros até ao meio do } \\
\text { rio, outros ainda até à } \\
\text { outra margem; todos no } \\
\text { entanto, pela } \\
\text { impetuosidade do rio ou } \\
\text { pelo pêso que levavam } \\
\text { às costas, finalmente } \\
\text { caíam e se afogavam." } \\
\text { - (p. 76). }\end{array}$ \\
\hline
\end{tabular}

incaricato - incaricare: investire qualcuno di un incarico, di una incombenza, missione, sim.

caricato-caricare: aggravare con un peso eccessivo; porre qualcuno o qualcosa sopra un sostegno o un mezzo di trasporto.

Em Atena/Ediouro traduz-se por Iprocuravaml os termos lcaricatil e lincaricatil. Temos, pelo contexto, o significado claro de que os "frati" carregavam pesos, estavam carregados.

A tradução Vozes pode dar lugar a ambigüidade, pois carregado, em português atual, é geralmente entendido como "levado por outrem".

- un luogo insieme di famiglia ( $F X X X V I I I)$.

\begin{tabular}{|c|c|c|c|}
\hline Newton & Garzanti & Atena/Ediouro & Vozes \\
\hline $\begin{array}{l}\text { "Dimorando una volta } \\
\text { in un luogo insieme di } \\
\text { famiglia santo } \\
\text { Francesco e frat'Elia, } \\
\text { fu rivelato da Dio..." - } \\
\text { (p. 68). }\end{array}$ & $\begin{array}{l}\text { "Dimorando una volta } \\
\text { in un luogo insieme di } \\
\text { famiglia santo } \\
\text { Francesco e frat'Elia, } \\
\text { fu rivelato da Dio..." - } \\
\text { (p. 115). }\end{array}$ & $\begin{array}{l}\text { "Achando-se uma vez } \\
\text { S. Francisco e Irmão } \\
\text { Elias servindo juntos } \\
\text { em um convento, foi } \\
\text { por Deus revelado..." - } \\
\text { (p. } 147 \text { e p.99 } \\
\text { respectivamente). }\end{array}$ & $\begin{array}{l}\text { "Habitando uma vez } \\
\text { juntos, de família, em } \\
\text { um convento, S. } \\
\text { Francisco e frei Elias, } \\
\text { foi revelado por } \\
\text { Deus..." - (p. 79). }\end{array}$ \\
\hline
\end{tabular}

\begin{tabular}{|c|c|c|c|}
\hline $\begin{array}{l}\text { Newton } \\
\text { “...fu posto di famiglia } \\
\text { nel detto luogo...” - (p } \\
\text { 79). }\end{array}$ & $\begin{array}{l}\text { Garzanti } \\
\text { “...fu posto di famigli } \\
\text { nel detto luogo..." - (p. } \\
\text { 139). }\end{array}$ & $\begin{array}{l}\text { Atena/Ediouro } \\
\text { “...foi pôsto a servir no } \\
\text { referido convento...” - } \\
\text { (p. } \mathbf{1 7 7} \text { e p. } \mathbf{1 1 7} \\
\text { respectivamente). }\end{array}$ & $\begin{array}{l}\text { Vozes } \\
\text { “...foi posto em família } \\
\text { no dito convento...” - } \\
\text { (p. 94). }\end{array}$ \\
\hline
\end{tabular}

Aqui é importante sublinhar os termos luogo e convento. A palavra luogo contrapõe a convento no contexto franciscano. Os franciscanos primitivos e os rigidamente 
pobres (como os de $I F$ ) não aceitavam morar em prédios (conventi) e sim em grutas ou tocas (luoghi). Temos tal ocorrência - a tradução de "luogo" por "convento" - durante todo o texto nas duas traduções. Coloco aqui apenas dois exemplos.

- $\quad$ chiunque $(F X X X V I I I)$.

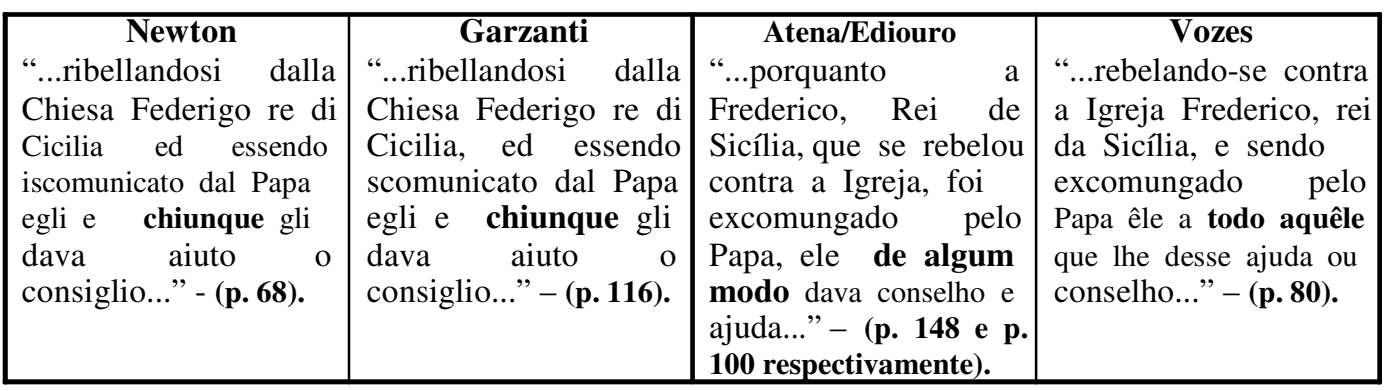

chiunque: qualunque persona.

Em Atena/Ediouro traduz-se por “de algum modo". Impropriedade denotativa.

Vozes enfatiza o masculino, ao passo que o original é menos ligado ao gênero (cf., em português, "quem quer que").

- $\quad$ recai $(F X L I)$.

\begin{tabular}{|c|c|c|c|}
\hline Newton & Garzanti & Atena/Ediouro & Vozes \\
\hline $\begin{array}{l}\text { “...Rendimi li miei } \\
\text { panni ch'io ci recai del } \\
\text { secolo..." - (p. 72). }\end{array}$ & $\begin{array}{l}\text { "Rendimi } \text { i miei panni } \\
\text { ch'io } \quad \text { recai del } \\
\text { secolo..." - }(\mathbf{p . 1 2 4 )} \text {. }\end{array}$ & $\begin{array}{l}\text { "Dá-me os meus panos, } \\
\text { que eu voltarei para o } \\
\text { século..." - (p. } 158 \text { e } \\
\text { p.105 } \\
\text { respectivamente). }\end{array}$ & $\begin{array}{l}\text { "Restitui-me as vestes } \\
\text { que trouxe do século...' } \\
-(\mathbf{p . 8 5}) .\end{array}$ \\
\hline
\end{tabular}

recare:

1. portare, condurre.

2. avere su di se.

3. arrecare, causare, produrre.

4. indurre.

5. tradurre (raro).

6. attribuire (lett). 
Atena/Ediouro - Ivoltareil. Além do significado do termo italiano não estar passado pelo vocábulo em português, o tempo verbal que no italiano é o passato remoto torna-se futuro do indicativo na tradução brasileira.

- fu posto di famiglia $(F X L V I)$.

\begin{tabular}{|c|c|c|c|}
\hline $\begin{array}{l}\text { Newton } \\
\text { “...fu posto di famiglia } \\
\text { nel detto luogo...” - (p. } \\
\text { 79). }\end{array}$ & $\begin{array}{l}\text { Garzanti } \\
\text { “...fu posto di famiglia } \\
\text { nel detto luogo...” - }(\mathbf{p .} \\
\text { 139). }\end{array}$ & $\begin{array}{l}\quad \text { Atena/Ediouro } \\
\text { “..ffoi pôsto a servir no } \\
\text { referido convento...” - } \\
\text { (p. } 177 \text { e p. } 117 \\
\text { respectivamente). }\end{array}$ & $\begin{array}{l}\text { Vozes } \\
\text { “...foi posto em família } \\
\text { no dito convento...” - } \\
\text { (p. 94). }\end{array}$ \\
\hline
\end{tabular}

Notar, novamente, a impropriedade da noção de "convento", ausente do original.

- $\quad$ discendendo di sotto (F XLVIII).

\begin{tabular}{|c|c|c|c|}
\hline Newton & Garzanti & Atena/Ediouro & Vozes \\
\hline $\begin{array}{l}\text { “...discendendo } \\
\text { sotto a tutti li rami..." } \\
\text { (p. 83). }\end{array}$ & $\begin{array}{l}\text { “...discendendo } \quad \text { di } \\
\text { sotto a tutti e rami..." - } \\
\text { (p. 146). }\end{array}$ & $\begin{array}{l}\text { "...e deixando todos os } \\
\text { ramos..." - (p. } 185 \text { e p. } \\
122 \text { respectivamente). }\end{array}$ & $\begin{array}{l}\text { "...e descendo abaixo } \\
\text { de todos os ramos..." - } \\
\text { (p. 98). }\end{array}$ \\
\hline
\end{tabular}

\section{discendere:}

1. scendere, andare giù;

2. calare, abassare.

João desce dos ramos. A tradução de Atena/Ediouro ao adotar o verbo "deixar" traz uma ambigüidade inexistente no original. O verbo, em português, pode nos levar a interpretar que o frate desceu dos ramos e/ou carregava estes ramos e não os carrega mais.

- divina Scrittura (F XLVIII).

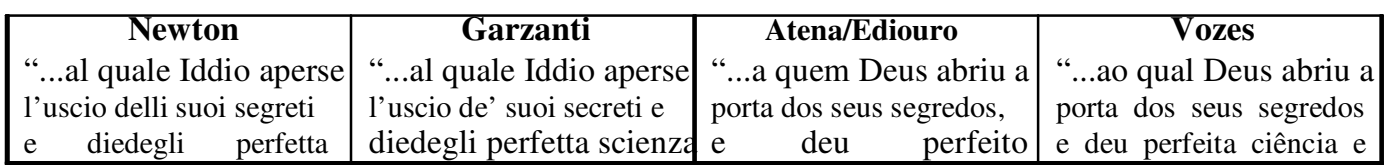




\begin{tabular}{|c|c|c|c|}
\hline $\begin{array}{l}\text { scienza e intelligenza } \\
\text { della } \\
\text { Scrittura..." - (p. divina }\end{array}$ & $\begin{array}{l}\text { e intelligenza della } \\
\text { divina Scrittura..." - } \\
\text { (p. 143). }\end{array}$ & $\begin{array}{l}\text { conhecimento } \mathrm{e} \\
\text { inteligência da divina } \\
\text { vontade..." - (p. } \mathbf{1 8 3} \mathrm{e} \\
\text { p. } \\
\text { resnectivamente) }\end{array}$ & $\begin{array}{l}\text { inteligência da divina } \\
\text { Escritura..." - (p. 97). }\end{array}$ \\
\hline
\end{tabular}

A versão das editoras Atena e Ediouro traz a tradução a palavra IScrittural por lvontadel.

- $\quad$ e pochi v'erano di quelli che $(F X L V I I I)$

\begin{tabular}{|c|c|c|c|}
\hline $\begin{array}{l}\text { Newton } \\
\text { "E dopo lui } \\
\text { seguentemente santo } \\
\text { Francesco il porgeva a } \\
\text { tutti gli altri, e pochi ve } \\
\text { n'erano di questi che } \\
\text { con debita reverenza e } \\
\text { divozione } \\
\text { prendessino e bevessino } \\
\text { tutto." - (p. 82-83). }\end{array}$ & $\begin{array}{l}\text { Garzanti } \\
\text { "E dopo lui } \\
\text { seguentemente santo } \\
\text { Francesco il porgeva a } \\
\text { tutti gli altri: e pochi } \\
\text { v'erano di quelli che } \\
\text { con debita reverenzia e } \\
\text { divozione il prendevano } \\
\text { e beveano tutto." - (p. } \\
\text { 145). }\end{array}$ & \begin{tabular}{l}
\multicolumn{1}{c}{ Atena/Ediouro } \\
"E depois, S. Francisco \\
o oferecia a todos os \\
outros; e houve poucos \\
que não o tomassem, e \\
bebessem todo com o \\
devido respeito e \\
devoção." - (p. 185 e p. \\
$\mathbf{1 2 2}$ respectivamente).
\end{tabular} & $\begin{array}{l}\text { Vozes } \\
\text { "E depois dele } \\
\text { sucessivamente S. } \\
\text { Francisco apresentou-o } \\
\text { a todos os outros: e } \\
\text { poucos eram os que o } \\
\text { bebiam todo." - (p. } \\
\text { 98). }\end{array}$ \\
\hline
\end{tabular}

Aqui a tradução de Atena/Ediouro modifica totalmente o sentido do texto. O tradutor insere uma negativa inexistente.

Vozes simplifica o original excluindo "debita reverenzia e divozione" (cf. p.).

- "agli ardori” (F XLIX).

\begin{tabular}{|c|c|c|c|}
\hline Newton & Garzanti & Atena/Ediouro & Vozes \\
\hline $\begin{array}{l}\text { “...alcuna volta agli } \\
\text { ardori de' } \\
\text { (p. 84). }\end{array}$ & $\begin{array}{l}\text { "...alcuna volta agli } \\
\text { ardori de' serafini..." - } \\
\text { (p. 149). }\end{array}$ & $\begin{array}{l}\text { “... "algumas vêzes ao } \\
\text { ardor dos Serafins"..." } \\
\text { - (p. } \mathbf{1 8 8} \text { e p. } \mathbf{1 2 4} \\
\text { respectivamente). }\end{array}$ & $\begin{array}{l}\text { "... de outras vêzes a } \\
\text { ardores de serafins..." } \\
-(\mathbf{p . ~ 1 0 0 )} \text {. }\end{array}$ \\
\hline
\end{tabular}

Enquanto os originais trazem o termo grifado no plural (assim como faz também

Vozes) Atena/Ediouro traduz pelo termo singular em português. 
- $\quad$ viottolo (F XLIX - Newton, pp. 85 e 86; Garzanti, pp. 150 e 152).

1. via stretta di campagna; sentiero fra i campi.

Temos em português: Iveredal35 e latalhol36.

\section{vereda:}

1. caminho estreito, senda.

2. atalho.

3. rumo, caminho, direção.

atalho:

1. atalhamento.

2. caminho fora da estrada comum para encurtar distâncias, o tempo do percurso; corte, vereda.

3. estorvo, embaraço, empecilho.

4. remate, fim.

A palavra latalhol possui uma carga semântica de caminho, mas o caminho mais curto (em italiano scorciatoia). O que não acontece com o termo italiano lviottolol.

- $\quad$ vide $(F L I)$.

\begin{tabular}{|c|c|c|c|}
\hline Newton & Garzantí & Atena/Ediouro & Vozes \\
\hline $\begin{array}{l}\text { "E allora io apparii a } \\
\text { frate Iacopo della } \\
\text { Massa, laico santo, il } \\
\text { quale serviva messa e } \\
\text { vide l'ostia consegrata, } \\
\text { quando il prete la levò, } \\
\text { convertita e mutata in } \\
\text { forma d'uno fanciullo } \\
\text { vivo bellissimo..." - (p. } \\
\mathbf{8 8} \text { ). }\end{array}$ & $\begin{array}{l}\text { "E allora io appari' a } \\
\text { frate Iacopo della } \\
\text { Massa, laico santo, il } \\
\text { quale serviva messa e } \\
\text { vide l'ostia consecrata, } \\
\text { quando il prete la levò, } \\
\text { convertita e mutata in } \\
\text { forma d'uno bellissim } \\
\text { fanciullo vivo..." - (p. } \\
\text { 156). }\end{array}$ & $\begin{array}{l}\text { "E então eu apareci a } \\
\text { Irmão Jacó da Massa, } \\
\text { leigo santo; o qual } \\
\text { ajudava à missa e vi a } \\
\text { hóstia na forma de um } \\
\text { belíssimo menino } \\
\text { vivo..." - (p. 197 e p. } \\
\mathbf{1 3 0} \text { respectivamente). }\end{array}$ & $\begin{array}{l}\text { "E então eu apareci a } \\
\text { frei Tiago da Massa, } \\
\text { leigo santo, o qual } \\
\text { servia a missa e viu a } \\
\text { hóstia consagrada, } \\
\text { quando o padre a } \\
\text { ergueu, convertida e } \\
\text { mudada na forma de } \\
\text { uma belíssima criança } \\
\text { viva..." - (p. 105). }\end{array}$ \\
\hline
\end{tabular}

35 CAPISTRANO: pp. 189, 190 e 192 (em Atena); pp. 125, 126, 127 (em Ediouro). 36 MORAIS: pp. 101 e 103. 
Erro denotativo em Atena/Ediouro: Ividel - passato remoto, $3^{\text {a }}$ pessoa do singular; |vil - pretérito perfeito, $1^{\mathrm{a}}$ pessoa do singular. Talvez falha de revisão ou composição gráfica, porém presentes nas três edições consultadas (Ediouro - sem data; Atena - sem data e 1937).

- contenere del gridare $(F L I I)$.

\begin{tabular}{|c|c|c|c|}
\hline $\begin{array}{l}\text { Newton } \\
\text { “...e per lo troppo } \\
\text { fervore dello amore non } \\
\text { si potea contenere del } \\
\text { gridare.” - (p. 89). }\end{array}$ & $\begin{array}{l}\text { Garzanti } \\
\text { “...e per lo troppo } \\
\text { fervore dello amore, } \\
\text { egli non si potea } \\
\text { contenere del gridare." } \\
\text { - (p. 157). }\end{array}$ & $\begin{array}{l}\text { Atena/Ediouro } \\
\text { “...e pelo muito fervor } \\
\text { do amor, não podia } \\
\text { deixar de gritar." }-(\mathbf{p} \\
\mathbf{1 9 9} \text { e p. } \mathbf{1 3 1} \\
\text { respectivamente). }\end{array}$ & $\begin{array}{l}\text { Vozes } \\
\text { “...e pelo fervor do } \\
\text { amor, ele não se podia } \\
\text { conter nem gritar." - } \\
\text { (p. 106). }\end{array}$ \\
\hline
\end{tabular}

A editora Vozes, em sua tradução, traz a impossibilidade do grito. Nos originais temos que o "frate" não conseguia se conter e gritava, como traduz Atena/Ediouro.

- $\quad$ incarnato (F LIII).

\begin{tabular}{|c|c|c|c|}
\hline Newton & Garzanti & Atena/Ediouro & Vozes \\
\hline $\begin{array}{l}\text { «...apparì Gesù Cristo } \\
\text { benedetto incarnato e } \\
\text { glorificato..." - (p. 90). }\end{array}$ & $\begin{array}{lr}\text { «...e apparve Gesù } \\
\text { Cristo } & \text { benedetto } \\
\text { incarnato } & \text { e } \\
\text { glorificato..." } & \text { (p. 161). }\end{array}$ & $\begin{array}{lr}\text { “...apareceu } & \text { Jesus } \\
\text { Cristo } & \text { bendito } \\
\text { encarnado } & \text { e } \\
\text { glorificado..." } & -(\mathbf{p . ~ 2 0 3} \\
\text { e } \quad \text { p. } & \mathbf{1 3 3} \\
\text { respectivamente). }\end{array}$ & $\begin{array}{l}\text { “...apareceu Jesus } \\
\text { Cristo bendito coroad } \\
\text { e glorificado..." - (p. } \\
\mathbf{1 0 8 ) .}\end{array}$ \\
\hline
\end{tabular}

incarnare:

1. dare corpo e figura, rappresentare concretamente e con efficacia;

2. ferire penetrando nella carne;

3. dipingere l'aspetto della carne umana;

4. prendere carne e figura umana;

5. concretarsi;

6. attacarsi, unirsi fortemente.

Em Vozes, traduz-se por lcoroadol. Provavelmente original com variante ("incoronato"). 
- $\quad$ in questo dire era alluminato dallo Spirito Santo $(F L I I I)$.

\begin{tabular}{|c|c|c|c|}
\hline $\begin{array}{l}\text { Newton } \\
\text { "E in questo dire era } \\
\text { alluminato dallo Spirito } \\
\text { Santo di tutti; profondi } \\
\text { e alti misteri di quello } \\
\text { altíssimo Sacramento." } \\
\text { - (p. 89). }\end{array}$ & $\begin{array}{l}\text { Garzanti } \\
\text { "E in questo dire era } \\
\text { illuminato dallo Spiritd } \\
\text { Santo di tutti i profondi } \\
\text { e alti misteri di quell } \\
\text { altíssimo Sacramento." } \\
\text { - (p. 159). }\end{array}$ & $\begin{array}{l}\text { Atena/Ediouro } \\
\text { “...e neste falar era } \\
\text { iluminado pelo Espírit } \\
\text { Santo por todos os } \\
\text { profundos e altos } \\
\text { mistérios daquele } \\
\text { altíssimo Sacramento." } \\
\text { - (p. 202 e p.132 } \\
\text { respectivamente). }\end{array}$ & $\begin{array}{l}\text { Vozes } \\
\text { "E neste dizer o espírito } \\
\text { Santo esclarecia-lhe } \\
\text { todos os profundos e } \\
\text { altos mistérios daquele } \\
\text { altíssimo sacramento." } \\
\text { - (p. 107). }\end{array}$ \\
\hline
\end{tabular}

Enfim o Espírito esclarece os mistérios - Vozes - ou o frate é iluminado pelo Espírito e pelos mistérios - Atena/Ediouro? A primeira solução corresponde ao sentido original.

- $\quad$ infra ( F LIII)

\begin{tabular}{|c|c|c|c|}
\hline $\begin{array}{l}\text { Newton } \\
\text { “...addivenne una volta } \\
\text { questo mirabile caso, } \\
\text { che la prima notte dopo } \\
\text { l'ottava di santo } \\
\text { Lorenzo e infra l'ottava } \\
\text { dell'Assunzione della } \\
\text { Donna...” - (p. 89). }\end{array}$ & $\begin{array}{l}\text { Garzanti } \\
\text { "...addivenne una volta } \\
\text { questo mirabile caso: } \\
\text { che la prima notte dopo } \\
\text { l'ottava di santo } \\
\text { Lorenzo e infra l'ottava } \\
\text { della Assunzione della } \\
\text { Donna..." - (pp. 158- } \\
\text { 159). }\end{array}$ & $\begin{array}{l}\text { Atena/Ediouro } \\
\text { “...aconteceu uma vez } \\
\text { êste admirável caso: } \\
\text { que a primeira noite } \\
\text { após a oitava de S. } \\
\text { Lourenço, e entre a } \\
\text { oitava da Assunção de } \\
\text { nossa Senhora...” - (p. } \\
\mathbf{2 0 1} \text { e p. } \mathbf{1 3 2} \\
\text { respectivamente). }\end{array}$ & $\begin{array}{l}\text { Vozes } \\
\text { “...sucedeu uma vez } \\
\text { êste caso admirável, } \\
\text { que na primeira noite } \\
\text { depois da oitava de S. } \\
\text { Lourenço e dentro da } \\
\text { Assunção de Nossa } \\
\text { Senhora...” - (p. 106). }\end{array}$ \\
\hline
\end{tabular}

Impropriedade em Atena/Ediouro.

Infra-intra: che sta dentro, nell'interno.

“...infra l'ottava..." = dentro da oitava, ou seja, dentro dos oito dias seguintes à festa.

- $\quad$ non gli era convenuto (F LIII).

\begin{tabular}{|c|c|c|c|}
\hline Newton & Garzanti & Atena/Ediouro & Vozes \\
\hline $\begin{array}{l}\text { "Ma imperò che altra } \\
\text { volta gli era addivenuto } \\
\text { simile caso, e "1 Signore } \\
\text { avea sì temperato } \\
\text { quello fervore che non } \\
\text { gli era convenuto }\end{array}$ & $\begin{array}{l}\text { "Ma imperò che altre } \\
\text { volte gli era addivenuto } \\
\text { simile caso, e "1 Signore } \\
\text { avea sì temperato quel } \\
\text { fervore che non gli era } \\
\text { convenuto lasciare la }\end{array}$ & $\begin{array}{l}\text { "Mas visto que já lhe } \\
\text { acontecera caso } \\
\text { idêntico, e o Senhor lhe } \\
\text { atenuara aquêle fervor, } \\
\text { que lhe fora } \\
\text { necessário deixar a }\end{array}$ & $\begin{array}{l}\text { "Mas porque de outra } \\
\text { vez lhe havia } \\
\text { acontecido caso } \\
\text { semelhante o o Senhor } \\
\text { havia de tal modo } \\
\text { temperado aquêle }\end{array}$ \\
\hline
\end{tabular}




\begin{tabular}{|l|l|l|l|}
\hline $\begin{array}{l}\text { lasciare la messa..." } \\
\text { (p. 90). }\end{array}$ & Messa..."-(p. 160). & $\begin{array}{l}\text { missa..."- (p. 202 e p. } \\
\mathbf{1 3 3} \text { respectivamente). }\end{array}$ & $\begin{array}{l}\text { fervor, que não lhe } \\
\text { fôra necessário deixar } \\
\text { a missa..."-(p. 107). }\end{array}$ \\
\hline
\end{tabular}

A edição Atena/Ediouro simplesmente substitui uma negativa por uma afirmativa.

\subsection{Dar com esta mão e tirar com a outra...}

Apontam-se a seguir casos em que as traduções apresentam omissões ou acréscimos, mais ou menos consideráveis.

- $\quad F I I$

\begin{tabular}{|c|c|c|c|}
\hline Newton & Garzanti & Atena/Ediouro & Vozes \\
\hline $\begin{array}{l}\text { "Per nessuno modo } \\
\text { puote che questo } \\
\text { Francesco non abbia } \\
\text { grande grazia di Dio." - } \\
\text { (p. 18). }\end{array}$ & $\begin{array}{l}\text { "Per niuno modo può } \\
\text { esser che questo } \\
\text { Francesco non abbia } \\
\text { grande grazia di Dio." } \\
\text { (p. 07). }\end{array}$ & $\begin{array}{lr}\text { "De nenhum } & \text { modo } \\
\text { pode ser que } & \text { êsse } \\
\text { Irmão não tenha } \\
\text { grande graça } \\
\text { Deus..." - } \text { (p. 15 e p. } 20 \\
\text { respectivamente). }\end{array}$ & $\begin{array}{lr}\text { "Não } & \text { posso } \\
\text { compreender que êste } \\
\text { Francisco não possua } \\
\text { grande graça de } \\
\text { Deus..." - (p. 10) }\end{array}$ \\
\hline
\end{tabular}

Aqui o acréscimo da palavra "Irmão" em Atena/Ediouro.

\begin{tabular}{|c|c|c|c|}
\hline \begin{tabular}{l}
\multicolumn{3}{c}{ Newton } \\
"E vedendo uno, \\
ch'avea nome messer \\
Salvestro, che santo \\
Francesco dava tanti \\
danari a poveri e facea \\
dare, stretto d'avarizia \\
disse a c santo \\
Francesco..."-(p.19).
\end{tabular} & $\begin{array}{l}\text { Garzanti } \\
\text { "Vedendo uno, ch'avea } \\
\text { nome messer Salvestro, } \\
\text { che santo Francesco } \\
\text { dava tanti danari a' } \\
\text { poveri e faceva dare, } \\
\text { istretto d'avarizia, disse } \\
\text { a santo Francesco..." - } \\
\text { (p. 11). }\end{array}$ & \begin{tabular}{l}
\multicolumn{2}{c|}{ Atena/Ediouro } \\
"E vendo uma pessoa, \\
chamada Senhor \\
Silvestre, que S. \\
Francisco dava e fazia \\
dar tanto dinheiro aos \\
pobres, instigado pela \\
avareza, disse a S. \\
Francisco..." - (p. $\mathbf{1 8}$ e \\
p. \\
respectivamente).
\end{tabular} & $\begin{array}{l}\text { Vozes } \\
\text { "Ora, vendo isto, um } \\
\text { por nome Silvestre, que } \\
\text { S. Francisco dava e } \\
\text { mandava dar tanto } \\
\text { dinheiro aos pobres, } \\
\text { cheio de avareza disse a } \\
\text { S. Francisco..." - (p. } \\
\text { 12). }\end{array}$ \\
\hline
\end{tabular}

Na edição Vozes, omite-se a tradução da palavra "messer". 
- $\quad F I V$

\begin{tabular}{|c|c|c|c|}
\hline Newton & Garzanti & Atena/Ediouro & Vozes \\
\hline $\begin{array}{l}\text { "Frate Elia non vuole } \\
\text { venire a me; ma va' e } \\
\text { di' a frate Francesco } \\
\text { ch'io son venuto per } \\
\text { parlare con lui; ma } \\
\text { però ch'io non voglio } \\
\text { impedire lui della } \\
\text { orazione, digli che } \\
\text { mandi a me frat'Elia" } \\
\text { - (p. 22) }\end{array}$ & $\begin{array}{l}\text { “- Frate Elia non vuole } \\
\text { venire a me; ma va', e } \\
\text { di' a frate Francesco } \\
\text { ch'io sono venuto per } \\
\text { parlare con lui; ma } \\
\text { però ch'io no 'I voglio } \\
\text { impedire dalla } \\
\text { orazione, digli che } \\
\text { mandi a me frate } \\
\text { Elia." - (p. 18). }\end{array}$ & $\begin{array}{l}\text { "Irmão Elias não quer } \\
\text { atender-me: mas vai, e } \\
\text { dize a Irmão Francisco } \\
\text { que vim para falar-lhe" } \\
\text { - (p. } 27 \text { e p. } \mathbf{2 6} \\
\text { respectivamente). }\end{array}$ & $\begin{array}{l}\text { "Respondeu o jovem: } \\
\text { Frei Elias não quis vir a } \\
\text { mim: vai e dize a frei } \\
\text { Francisco que vim para } \\
\text { falar com êle; mas, por } \\
\text { não querer perturbar- } \\
\text { lhe a oração, dize-lhe } \\
\text { que mande frei Elias } \\
\text { entender-se comigo." - } \\
\text { (p. 16). }\end{array}$ \\
\hline
\end{tabular}

O trecho em negrito é omitido na tradução de Atena/Ediouro.

- $F X$

\begin{tabular}{|c|c|c|c|}
\hline $\begin{array}{l}\text { Newton } \\
\text { “... ma chi si gloria, si } \\
\text { glorii nel Signore, a cui } \\
\text { è ogni onore e gloria in } \\
\text { eterno.” - (p. 31). }\end{array}$ & $\begin{array}{l}\text { Garzanti } \\
\text { “... ma chi si gloria, si } \\
\text { glorii nel Signore a cui } \\
\text { è ogni onore e gloria in } \\
\text { eterno.” - }(\mathbf{p . ~ 3 1 ) .}\end{array}$ & \begin{tabular}{l}
\multicolumn{3}{c|}{ Atena/Ediouro } \\
“.. mas, quem se \\
glorificar, que se \\
glorifique, agora e \\
para o futuro, no \\
Senhor, ao qual cabem \\
todas as honras, e a \\
glória eterna.” - (p. 50 \\
e p. p. \\
respectivamente).
\end{tabular} & $\begin{array}{l}\text { Vozes } \\
\text { “...mas quem se gloriar } \\
\text { se glorie no Senhor, a } \\
\text { quem pertence tôda a } \\
\text { honra e glória na } \\
\text { eternidade." - (p. 27). }\end{array}$ \\
\hline
\end{tabular}

Acréscimo de trecho em Atena/Ediouro.

- $\quad F X I V$

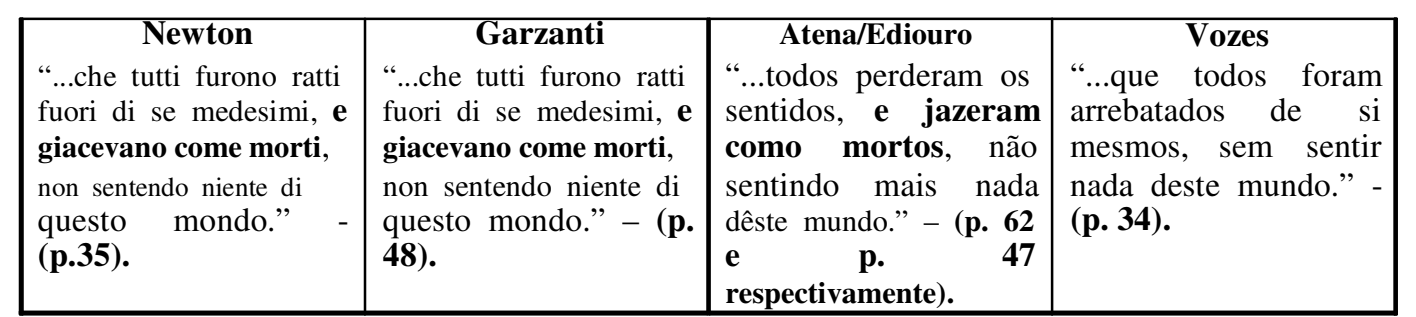

Omissão do trecho grifado em Vozes. 


\begin{tabular}{|c|c|c|c|}
\hline Newton & Garzanti & Atena/Ediouro & Vozes \\
\hline 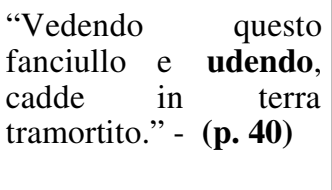 & $\begin{array}{l}\text { "Veggendo questo il } \\
\text { fanciullo e udendo, } \\
\text { cadde in terra } \\
\text { tramortito." - }(\mathbf{p . ~ 5 8 )}\end{array}$ & $\begin{array}{l}\text { "Vendo e ouvindo isto, } \\
\text { o rapaz caiu por terra } \\
\text { desfalecido." - (p.74 e } \\
\text { p. } \\
\text { respectivamente). }\end{array}$ & $\begin{array}{l}\text { "Vendo isto, o menin } \\
\text { caiu no chão sem } \\
\text { sentidos..." - (p. 40) }\end{array}$ \\
\hline
\end{tabular}

O verbo "udendo" é omitido na tradução da editora Vozes.

- $\quad F X V I I$

\begin{tabular}{|c|c|c|c|}
\hline Newton & Garzanti & Atena/Ediouro & Vozes \\
\hline $\begin{array}{l}\text { “..trovò il detto } \\
\text { fanciullo, col piè, } \\
\text { giacere nella via come } \\
\text { morto, e per } \\
\text { compassione sì lo levò } \\
\text { e arrecollosi in braccia } \\
\text { e portollo come fa il } \\
\text { buono pastore alle sue } \\
\text { pecore." - (p. 40). }\end{array}$ & $\begin{array}{l}\text { “...co' piedi trovò il } \\
\text { detto fanciullo giacere } \\
\text { nella via come morto, e } \\
\text { per compassione sel } \\
\text { levò in braccio e } \\
\text { riportollo a letto, come } \\
\text { fa il buono pastore la } \\
\text { sua pecora." - (p. 58). }\end{array}$ & $\begin{array}{l}\text { “...encontrou o dito } \\
\text { rapaz que jazia como } \\
\text { morto; e por compaixão } \\
\text { o ergueu, e o recolheu } \\
\text { nos braços, como faz o } \\
\text { bom pastor às suas } \\
\text { ovelhas.”- (p. } 74 \text { e p. } \\
\text { 53 respectivamente). }\end{array}$ & $\begin{array}{l}\text { “...tropeçou no corpo do } \\
\text { menino que jazia na } \\
\text { estrada como morto, e } \\
\text { por compaixão } \\
\text { carregou-o nos braços e } \\
\text { colocou-o no leito } \\
\text { como faz o bom pastor } \\
\text { com a sua ovelha.” - } \\
(\mathbf{p . 4 0 ) .}\end{array}$ \\
\hline
\end{tabular}

Omissão em Atena/Ediouro.

- $\quad F X X$

\begin{tabular}{|c|c|c|c|}
\hline $\begin{array}{l}\text { Trecho } \\
\text { Os trechos a e b do } \\
\text { original converteram-se } \\
\text { em apenas duas linhas! }\end{array}$ & $\begin{array}{l}\text { Newton } \\
\text { (a): “...qualunque ora } \\
\text { egli passava dinanzi } \\
\text { all'altare del convento, } \\
\text { nel quale si conservava } \\
\text { il corpo di Cristo, } \\
\text { d'inginocchiarsi con } \\
\text { gran riverenza e trarsi il } \\
\text { cappuccio e colle } \\
\text { braccia cancellate } \\
\text { inchinarsi." - (p. } 44) \text {. } \\
\text { (b): "Addivenne che la } \\
\text { notte, nella quale si } \\
\text { dovea partire e uscire } \\
\text { dell'Ordine, convenne }\end{array}$ & \begin{tabular}{l}
\multicolumn{2}{c}{ Atena/Ediouro } \\
“...êle passava algumas \\
horas diante do altar do \\
convento; e passando, \\
segundo o uso, \\
ajoelhou-se e fez \\
reverência." - (p. 85 e \\
p.61 respectivamente).
\end{tabular} & $\begin{array}{l}\text { Garzanti } \\
\text { (a)“...qualunque ora e' } \\
\text { passava dinanzi } \\
\text { all'altare del convento } \\
\text { nel quale si conservava } \\
\text { il Corpo di Cristo, } \\
\text { d'inginocchiarsi con } \\
\text { grande riverenza e trarsi } \\
\text { il cappuccio e colle } \\
\text { braccia cancellate } \\
\text { inchinarsi." - (p. 67). } \\
\text { (b) "Avvenne che } \\
\text { quella notte, nella quale } \\
\text { egli si dovea partire e } \\
\text { uscire dell'Ordine, }\end{array}$ \\
\hline
\end{tabular}




\begin{tabular}{|l|l|l|l|}
\hline & $\begin{array}{l}\text { ch'e' passasse dinnanzi } \\
\text { all'altare del convento; } \\
\text { e passandovi secondo } \\
\text { l'usanza s'inginocchiò } \\
\text { fece riverenza." - (p. } \\
\text { 44). }\end{array}$ & $\begin{array}{l}\text { convenne ch'e' } \\
\text { passasse dinanzi } \\
\text { all'altare del convento; } \\
\text { e passandovi, secondo } \\
\text { l'usanza s'inginocchiò } \\
\text { fece riverenza." - (p. } \\
\text { 67). }\end{array}$ \\
\hline
\end{tabular}

Atena/Ediouro resumem em 2 linhas trecho original de 6 linhas (Newton) e 7 linhas (Garzanti).

- $\quad F X X I$

\begin{tabular}{|c|c|c|c|}
\hline $\begin{array}{l}\text { Newton } \\
\text { “... in tanto che tutti i } \\
\text { cittadini stavano in } \\
\text { gran paura, però che } \\
\text { spesse volte s'apressava } \\
\text { alla città...” - (p. 45). }\end{array}$ & $\begin{array}{l}\text { Garzanti } \\
\text { “... in tanto che tutti i } \\
\text { cittadini stavano in } \\
\text { gran paura, però che } \\
\text { spesse volte s'apressava } \\
\text { alla città." - (p. 69). }\end{array}$ & 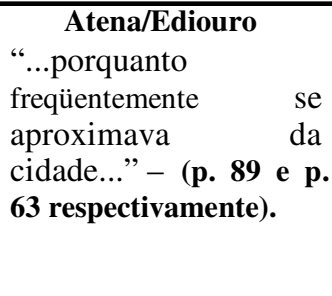 & $\begin{array}{l}\text { Vozes } \\
\text { “...de modo que todos } \\
\text { os citadinos estavam } \\
\text { tomados de grande } \\
\text { mêdo, porque } \\
\text { freqüentes vêzes êle se } \\
\text { aproximava da } \\
\text { cidade...”-(p. 47). }\end{array}$ \\
\hline
\end{tabular}

Omissão em Atena/Ediouro.

\begin{tabular}{|c|c|c|c|}
\hline Newton & Garzanti & Atena/Ediouro & Vozes \\
\hline $\begin{array}{l}\text { "Vieni qui, frate lupo, } \\
\text { io ti comando dalla } \\
\text { parte di Cristo..." - (p. } \\
\text { 45). }\end{array}$ & $\begin{array}{l}\text { "Vieni qua, frate lupo; } \\
\text { io ti comando dalla } \\
\text { parte di Cristo..." - (p. } \\
\text { 70). }\end{array}$ & $\begin{array}{l}\text { "Vem aqui, lôbo; eu te } \\
\text { ordeno da parte de } \\
\text { Cristo..." - (p. } 90 \text { e p. } \\
\mathbf{6 3} \text { respectivamente). }\end{array}$ & $\begin{array}{l}\text { "Vem cá, irmão lôbo, } \\
\text { ordeno-te da parte de } \\
\text { Cristo..." - (p. } \mathbf{4 8}) \text {. }\end{array}$ \\
\hline
\end{tabular}

Omissão da tradução da palavra "frate" em

Atena/Ediouro. Esta omissão é considerada grave, já que é justamente quando São Francisco chama o lobo de 'irmão', característica muito forte da figura de Francisco - colocar a natureza, os animais como criaturas de Deus, assim como os seres humanos.

- $\quad F X X I I$

\begin{tabular}{|l|ll|l|l|lr|}
\hline Newton & \multicolumn{2}{|c|}{ Garzanti } & \multicolumn{2}{c|}{ Atena/Ediouro } & \multicolumn{2}{c|}{ Vozes } \\
"Un giovane aveva & "Uno giovane avea & "Um jovem apanhara & "Um jovem havia \\
preso un dì molte & prese un dì molte & um dia muitas rôlas: e & apanhado um dia \\
tortole, e portavale a & tortore, e portavale a & levando para vender os & muitas rolas e levava-as \\
\hline
\end{tabular}




\begin{tabular}{|c|c|c|c|}
\hline $\begin{array}{l}\text { vendere. Iscontrandosi } \\
\text { in lui santo Francesco, } \\
\text { il quale sempre avea } \\
\text { singulare pietà agli } \\
\text { animali mansueti, } \\
\text { riguardando quelle } \\
\text { tortole con l'occhio } \\
\text { pietoso, disse al } \\
\text { giovane..." - (p. 47). }\end{array}$ & $\begin{array}{l}\text { vendere. Iscontrandosi } \\
\text { in lui santo Francesco, } \\
\text { il quale sempre avea } \\
\text { singulare pietà agli } \\
\text { animali mansueti, } \\
\text { ragguardando quelle } \\
\text { tortore con l'occhio } \\
\text { pietoso, sì disse a que } \\
\text { giovane..."-(p. 73). }\end{array}$ & $\begin{array}{l}\text { mansos bichinhos, S. } \\
\text { Francisco, olhando } \\
\text { aquelas rolas com olhos } \\
\text { piedosos, disse ao } \\
\text { jovem"-(p. } 93 \text { e p. } \mathbf{6 6} \\
\text { respectivamente). }\end{array}$ & $\begin{array}{l}\text { a vender. Encontrando- } \\
\text { o S. Francisco, o qual } \\
\text { sempre sentia singular } \\
\text { piedade pelos animais } \\
\text { mansos, olhando com } \\
\text { os olhos piedosos } \\
\text { aquelas rolas, disse ao } \\
\text { jovem..." - (p. 50). }\end{array}$ \\
\hline
\end{tabular}

Atena/Ediouro novamente resume trecho.

\begin{tabular}{|c|c|c|c|}
\hline Newton & Garzanti & Atena/E & Voze \\
\hline $\begin{array}{l}\text { "Ed ellenò, usandosi, } \\
\text { cominciarono a fare } \\
\text { uova e figliare dinanzi } \\
\text { alli frati, e così } \\
\text { dimesticamente si } \\
\text { stavano e usavano con } \\
\text { santo Francesco e con } \\
\text { gli altri frati, come se } \\
\text { fussono state galline } \\
\text { sempre nutricate da } \\
\text { loro." - (p. 47). }\end{array}$ & $\begin{array}{l}\text { "Ed elleno usandogli, } \\
\text { cominciarono a fare } \\
\text { uova e figliare innanz } \\
\text { a' frati; e così } \\
\text { dimesticamente si } \\
\text { stavano e usavano con } \\
\text { santo Francesco e con } \\
\text { gli altri frati, come } \\
\text { s'elle fussino state } \\
\text { galline sempre nutricate } \\
\text { da loro." - (p. 74). }\end{array}$ & $\begin{array}{l}\text { "...e elas, aninhando-se, } \\
\text { começaram a botar ôvo, } \\
\text { e a ter filhotes diante } \\
\text { dos Irmãos: "e tão } \\
\text { domesticamente viviam } \\
\text { em relações com S. } \\
\text { Francisco e com os } \\
\text { outros Irmãos", como } \\
\text { se fôssem galinhas, } \\
\text { sempre alimentadas por } \\
\text { êles..."-(p. 93 e p. } 66 \\
\text { respectivamente). }\end{array}$ & $\begin{array}{l}\text { "E elas, usando-os, } \\
\text { começaram a pôr ovos e } \\
\text { criar os filhos diante } \\
\text { dos frades: e assim } \\
\text { domesticamente vivian } \\
\text { e tratavam com S. } \\
\text { Francisco e com os } \\
\text { outros frades, como se } \\
\text { fôssem galinhas sempre } \\
\text { criadas por êles." - (p. } \\
\mathbf{5 0 ) .}\end{array}$ \\
\hline
\end{tabular}

Aspas em Atena/Ediouro inexistentes no original.

- $\quad F X X V$

\begin{tabular}{|c|c|c|c|}
\hline Newton & Garzanti & Atena/Ediouro & Vozes \\
\hline $\begin{array}{l}\text { "Riconoscimi tu? Qual } \\
\text { se' tu?, disse santo } \\
\text { Francesco." - (p. 51). }\end{array}$ & $\begin{array}{l}\text { "Riconoscimi tu? Qua } \\
\text { se' tu?, disse santo } \\
\text { Francesco." - (p. 82). }\end{array}$ & $\begin{array}{l}\text { "Reconheces-me?" - (p. } \\
104 \text { e p. } \\
\text { respectivamente). }\end{array}$ & $\begin{array}{l}\text { "Reconheces-me? } \\
\text { Quem és? disse S. } \\
\text { Francisco." - (p. 56). }\end{array}$ \\
\hline
\end{tabular}

Omissão em Atena/Ediouro.

- $\quad F X L I$

\begin{tabular}{|c|c|c|c|}
\hline Newton & Garzanti & Atena/Ediouro & Vozes \\
\hline $\begin{array}{l}\text { "Allora frate Simone, } \\
\text { secondo ch'egli avea } \\
\text { usato di fare, li fece } \\
\text { sedere allato a sé; e }\end{array}$ & $\begin{array}{l}\text { "Allora frate Simone, } \\
\text { secondo che avea usato } \\
\text { di fare, il fece sedere } \\
\text { allato a sé; e }\end{array}$ & $\begin{array}{l}\text { "Então Irmão Simão, } \\
\text { segundo o que } \\
\text { costumava fazer, o fêzz } \\
\text { sentar-se ao seu lado; e }\end{array}$ & $\begin{array}{l}\text { "Então frei Simão, } \\
\text { como costumava, o fêz } \\
\text { sentar-se ao seu lado e } \\
\text { falando-lhe de Deus, o }\end{array}$ \\
\hline
\end{tabular}




\begin{tabular}{|c|c|c|c|}
\hline $\begin{array}{l}\text { parlandogli di Dio, il } \\
\text { giovane inchinò il capo } \\
\text { in grembo a frate } \\
\text { Simone per malinconia } \\
\text { e per tristizia. Allora } \\
\text { frate Simone, per } \\
\text { grande compassione } \\
\text { che gli aveva, levò gl } \\
\text { occhi in cielo e } \\
\text { pregando Iddio } \\
\text { divotissimamente per } \\
\text { lui, fu ratto e esaudito } \\
\text { da Dio..." - (p. } \mathbf{7 2} \text { ). }\end{array}$ & $\begin{array}{l}\text { parlandogli di Dio, il } \\
\text { giovane inchinò il capo } \\
\text { in grembo a frate } \\
\text { Simone per malinconia } \\
\text { e per tristizia. Allora } \\
\text { frate Simone per grande } \\
\text { compassione che gli } \\
\text { avea, levò gli occhi in } \\
\text { cielo e, pregando Iddio } \\
\text { divotissimamente per } \\
\text { lui, fu ratto ed esaudito } \\
\text { da Dio."-(p. 124). }\end{array}$ & $\begin{array}{l}\text { falando-lhe de Deus, o } \\
\text { jovem inclinou a cabeça } \\
\text { no regaço de Irmão } \\
\text { Simão, que, pela grande } \\
\text { compaixão que tinha, } \\
\text { ergueu os olhos ao céu } \\
\text { e fêz uma oração, } \\
\text { pedindo a Deus } \\
\text { devotisismamente por } \\
\text { êle, e foi arrebatado e } \\
\text { atendido por Deus..." - } \\
\text { (p. } \mathbf{1 5 9} \text { e p. } \mathbf{1 0 5} \\
\text { respectivamente). }\end{array}$ & $\begin{array}{l}\text { jovem encostou a } \\
\text { cabeça no peito de frei } \\
\text { Simão por melancolia } \\
\text { e tristeza. Então frei } \\
\text { Simão, pela grande } \\
\text { compaixão que dele } \\
\text { tinha, levantou os olhos } \\
\text { ao céu e rogando a } \\
\text { Deus devotissimamente } \\
\text { por ele, foi arrebatado e } \\
\text { ouvido por Deus..." - } \\
\text { (p. 85). }\end{array}$ \\
\hline
\end{tabular}

Omissão em Atena/Ediouro.

- $\quad F X L V I$

\begin{tabular}{|c|c|c|c|}
\hline Newton & Garzanti & Atena/Ediouro & Vozes \\
\hline $\begin{array}{l}\text { “...imperò che, } \\
\text { benedetto sia Iddio, e' } \\
\text { non mi ha tratto, come } \\
\text { voi credete, amore } \\
\text { carnale..." - (p. 80). }\end{array}$ & $\begin{array}{l}\text { "...imperò che, } \\
\text { benedetto sia Iddio che } \\
\text { lo sa, che non m'ha } \\
\text { tratto, come credete, } \\
\text { amore carnale..." - (p. } \\
\text { 139). }\end{array}$ & $\begin{array}{l}\text { “...porquanto, bendito } \\
\text { seja Deus, êle não teve } \\
\text { por mim, como pensais, } \\
\text { nenhum amor carnal...” } \\
\text { - (p. } \mathbf{1 7 8} \text { e p. } \mathbf{1 1 7} \\
\text { respectivamente). }\end{array}$ & $\begin{array}{l}\text { “..porque, bendito seja } \\
\text { Deus, não se trata, } \\
\text { como credes, de amor } \\
\text { carnal..." - (p. 95). }\end{array}$ \\
\hline
\end{tabular}

\section{Omissão em Vozes.}

Nos originais e na tradução Atena/Ediouro temos a marca de 1a pessoa - "mi" / "mim" - que desaparece em Vozes.

\begin{tabular}{|c|c|c|c|}
\hline Newton & Garzanti & Atena/Ediouro & Vozes \\
\hline $\begin{array}{l}\text { "..orando io in luogo } \\
\text { diserto e remoto da } \\
\text { lui..." - (p. 80). }\end{array}$ & $\begin{array}{l}\text { "...orando io in luogo } \\
\text { diserto e remoto da } \\
\text { lui..." - (p. 139). }\end{array}$ & $\begin{array}{l}\text { “...quando eu orava em } \\
\text { um lugar deserto e } \\
\text { distante do lugar em } \\
\text { que ele } \\
\text { encontrava..." - (p. } \mathbf{1 7 8} \\
\text { e pe p. } \\
\text { respectivamente). }\end{array}$ & $\begin{array}{l}\text { “...orando eu em um } \\
\text { lugar deserto e } \\
\text { afastado..." - (p.95). }\end{array}$ \\
\hline
\end{tabular}

Omissão em Vozes.

Nos originais e na tradução de Atena/Ediouro fica claro que frate Pacífico está longe, afastado "dele", de frate Humilde. Em Vozes, o frate está apenas afastado. 


\begin{tabular}{|c|c|c|c|}
\hline Newton & Garzanti & Atena/Ediouro & Vozes \\
\hline $\begin{array}{l}\text { "...il quale fa così } \\
\text { maravigliose cose a' } \\
\text { santi suoi frati." - (p. } \\
\text { 80). }\end{array}$ & $\begin{array}{l}\text { "...il quale fa così } \\
\text { maravigliose cose a' } \\
\text { santi suoi." - (p. 139). }\end{array}$ & $\begin{array}{l}\text { “... “o qual faz tão } \\
\text { maravilhosas coisas aos } \\
\text { seus Santos Irmãos." - } \\
\text { (p. } \mathbf{1 7 8} \text { e p. } \mathbf{1 1 8} \\
\text { respectivamente). }\end{array}$ & $\begin{array}{l}\text { "...o qual faz assim } \\
\text { coisas maravilhosas aos } \\
\text { santos frades seus." - } \\
\text { (p. 95). }\end{array}$ \\
\hline
\end{tabular}

Acréscimo em Atena/Ediouro. As aspas não existem no original.

- $\quad F X L V I I I$

\begin{tabular}{|c|c|c|c|}
\hline $\begin{array}{l}\text { Newton } \\
\text { “...e davagli uno calice } \\
\text { pieno di spirito di vita e } \\
\text { mandavalo dicendo: } \\
\text { 'Va' e visita li frati } \\
\text { tuoi, e da' loro bere di } \\
\text { questo calice dello } \\
\text { spirito della vita, } \\
\text { imperò che lo ispirito di } \\
\text { Satana si leverà contro } \\
\text { a loro e percoteragli, e } \\
\text { molti di loro cadranno e } \\
\text { non si rileveranno.”" - } \\
\text { (p. 82). }\end{array}$ & $\begin{array}{l}\text { Garzanti } \\
\text { “...e davagli uno calice } \\
\text { pieno di spirito di vita, } \\
\text { e mandavalo dicendo: } \\
\text { 'Va', e visita i frati } \\
\text { tuoi, e da' loro bere di } \\
\text { questo calice dello } \\
\text { spirito della vita; } \\
\text { imperò che lo spirito di } \\
\text { Satanasso si leverà } \\
\text { contro di loro e } \\
\text { percoteragli; e molti di } \\
\text { loro caderanno, e non si } \\
\text { leveranno."”- (p. 145). }\end{array}$ & \begin{tabular}{l}
\multicolumn{2}{|c|}{ Atena/Ediouro } \\
“...e lhe dava um cálice \\
do espírito de vida; \\
porquanto o espírito de \\
Satanás se erguerá \\
contra êles, os \\
perseguirá, e muitos \\
deles cairão e não se \\
levantarão.” - (p. $\mathbf{1 8 5}$ e \\
p. \\
respectivamente).
\end{tabular} & $\begin{array}{l}\text { Vozes } \\
\text { “... e dava-lhe um cálice } \\
\text { cheio de espírito de } \\
\text { vida, e ordenava-lhe, } \\
\text { dizendo: Vai e visita } \\
\text { teus frades e dá-lhes } \\
\text { de beber dêste cálice } \\
\text { do espírito de vida, } \\
\text { porque o espírito de } \\
\text { Satanás se levantará } \\
\text { contra eles e os } \\
\text { combaterá e muitos } \\
\text { dêles cairão e não se } \\
\text { levantarão.” - (p. 98). }\end{array}$ \\
\hline
\end{tabular}

Omissão de trecho em Atena/Ediouro.

- $\quad F$ XLVIII

\begin{tabular}{|c|c|c|c|}
\hline Newton & Garzanti & Atena/Ediour & Durval de Morais \\
\hline $\begin{array}{l}\text { "E lopo lui } \\
\text { seguentemente santo } \\
\text { Francesco il porgeva a } \\
\text { tutti gli altri, e pochi ve } \\
\text { n'erano di questi che } \\
\text { con debita reverenza e } \\
\text { divozione il } \\
\text { prendessino e bevessino } \\
\text { tutto." - (p. 82-83). }\end{array}$ & $\begin{array}{l}\text { "E dopo lui } \\
\text { seguentemente santo } \\
\text { Francesco il porgeva a } \\
\text { tutti gli altri: e pochi } \\
\text { v'erano di quelli che } \\
\text { con debita reverenzia } \\
\text { e divozione il } \\
\text { prendevano e beveano } \\
\text { tutto." - (p. 145). }\end{array}$ & $\begin{array}{l}\text { "E depois, S. Francisco } \\
\text { o oferecia a todos os } \\
\text { outros; e houve poucos } \\
\text { que não o tomassem, e } \\
\text { bebessem todo com o } \\
\text { devido respeito } \\
\text { devoção." - (p. } \mathbf{1 8 5} \text { e } \\
\text { p. } \\
\text { respectivamente). }\end{array}$ & $\begin{array}{l}\text { "E depois dele } \\
\text { sucessivamente S. } \\
\text { Francisco apresentou-o } \\
\text { a todos os outros: e } \\
\text { poucos eram os que o } \\
\text { bebiam todo." - (p. 98). }\end{array}$ \\
\hline
\end{tabular}

Omissão em Vozes. 


\begin{tabular}{|c|c|c|c|}
\hline $\begin{array}{l}\text { Newton } \\
\text { "E detto questo, si partì } \\
\text { quella anima. Allora } \\
\text { frate Currado, per dare } \\
\text { allegrezza e conforto } \\
\text { alli frati, loro recitò per } \\
\text { ordine tutta questa } \\
\text { visione. } \\
\text { A laude di Gesù Cristo } \\
\text { e del poverello } \\
\text { Francesco. Amen." - } \\
\text { (p. 76) }\end{array}$ & $\begin{array}{l}\text { Garzanti } \\
\text { "E detto questo, si partì } \\
\text { quella anima. Allora } \\
\text { frate Currado, per dare } \\
\text { allegrezza e conforto a' } \\
\text { frati, recitò loro per } \\
\text { ordine tutta quella } \\
\text { visione. A laude di } \\
\text { Cristo , benedetto. } \\
\text { Amen." - (p. 131). }\end{array}$ & $\begin{array}{l}\text { Atena/Ediouro } \\
\text { “...e dito isto, a alma se } \\
\text { retirou. Então Irmão } \\
\text { Conrado, para dar } \\
\text { alegria e conforto aos } \\
\text { Irmãos, contou-lhes } \\
\text { direito tôda esta visão. } \\
\text { E assim foi para o } \\
\text { paraíso a alma } \\
\text { daquele menino, pelos } \\
\text { méritos de Frei } \\
\text { Conrado." - (p. } \mathbf{1 6 7} \text { e } \\
\text { p. } \\
\text { respectivamente). }\end{array}$ & $\begin{array}{l}\text { Vozes } \\
\text { "E dito isto partiu } \\
\text { aquela alma. Então frei } \\
\text { Conrado, para dar } \\
\text { alegria e confôrto aos } \\
\text { frades, lhes contou por } \\
\text { ordem tôda aquela } \\
\text { visão. Em louvor de } \\
\text { Cristo bendito. Amém." } \\
\text { - (p. 89). }\end{array}$ \\
\hline
\end{tabular}

\section{Acréscimo em Atena/Ediouro}

\begin{tabular}{|c|c|c|c|}
\hline $\begin{array}{l}\text { Newton } \\
\text { "E allora venne santo } \\
\text { Francesco a porgere il } \\
\text { calice della vita alli suoi } \\
\text { frati, e cominciò a } \\
\text { porgerlo a } \text { frate } \\
\text { Giovanni, il quale } \\
\text { prendendolo il bevette } \\
\text { tutto quanto in fretta..." } \\
\text { - (p. 82). }\end{array}$ & $\begin{array}{l}\text { Garzanti } \\
\text { "E allora venne santo } \\
\text { Francesco a porgere il } \\
\text { calice della vita a' suoi; } \\
\text { e cominciò a porgerlo a } \\
\text { frate Giovanni, il quale } \\
\text { prendendolo il bevè } \\
\text { tutto quanto in fretta..." } \\
\text { - (p. 145). }\end{array}$ & $\begin{array}{l}\text { Adelino Capistrano } \\
\text { "E então S. Francisco } \\
\text { veio oferecer o cálice } \\
\text { da vida aos seus } \\
\text { Irmãos: e começou por } \\
\text { oferecê-lo a Irmão João } \\
\text { de Parma; o qual, } \\
\text { tomando-o, o bebeu } \\
\text { todo, apressada e } \\
\text { devotamente..." - (p. } \\
\text { 185 e p. } \mathbf{1 2 2} \\
\text { respectivamente). }\end{array}$ & $\begin{array}{l}\text { Durval de Morais } \\
\text { "E então veio S. } \\
\text { Francisco apresentar o } \\
\text { cálice da vida aos seus } \\
\text { frades, e começou a } \\
\text { apresentá-lo a frei João } \\
\text { de Parma, o qual } \\
\text { tomando-o bebeu-o } \\
\text { todo depressa..." - (p. } \\
\text { 98). }\end{array}$ \\
\hline
\end{tabular}

Acréscimo em Atena/Ediouro e Vozes. Possível variante de fonte consultada.

\begin{tabular}{|c|c|c|c|}
\hline $\begin{array}{l}\text { Newton } \\
\text { "E frate Bonaventura, } \\
\text { il quale avea parte preso } \\
\text { del calice e parte n' avea } \\
\text { versato..." - (p. 83). }\end{array}$ & $\begin{array}{l}\text { Garzanti } \\
\text { "E frate Bonaventura, } \\
\text { il quale avea parte preso } \\
\text { del calice e parte n'avea } \\
\text { versato..." - (p. 146). }\end{array}$ & $\begin{array}{l}\text { Atena/Ediouro } \\
\text { “...e um Irmão, o qual } \\
\text { em parte bebera do } \\
\text { cálice, e em parte o } \\
\text { derramara...”- (p. } \mathbf{1 8 6} \\
\text { e p. } \quad \mathbf{1 2 2} \\
\text { respectivamente). }\end{array}$ & $\begin{array}{l}\text { Vozes } \\
\text { "E frei Bonaventura, o } \\
\text { qual havia bebido parte } \\
\text { do cálice e parte } \\
\text { derramado..." - (p. 98). }\end{array}$ \\
\hline
\end{tabular}




\begin{tabular}{|c|c|c|c|}
\hline Newton & Garzanti & Atena/Ediouro & Vozes \\
\hline $\begin{array}{l}\text { "Va' con questa pietra e } \\
\text { taglia l'unghie di frat }\end{array}$ & $\begin{array}{l}\text { "Va' con questa pietra e } \\
\text { taglia l'unghie di frat }\end{array}$ & $\begin{array}{l}\text { "Vai com esta pedra, e } \\
\text { corta as unhas daquele }\end{array}$ & $\begin{array}{l}\text { "Vai com esta pedra e } \\
\text { corta as unhas de frei }\end{array}$ \\
\hline $\begin{array}{l}\text { Bonaventura" - } \quad \text { (p. } \\
\text { 83). }\end{array}$ & $\begin{array}{l}\text { Bonaventura" - }(p . \\
\text { 146). }\end{array}$ & $\begin{array}{l}\text { Irmão..." - (p. } 186 \text { e p. } \\
123 \text { respectivamente). }\end{array}$ & $\begin{array}{l}\text { Bonaventura..." - (p. } \\
\text { 99). }\end{array}$ \\
\hline
\end{tabular}

Omissão em Atena/Ediouro por duas vezes.

Os originais e a tradução dada por Vozes especificam o nome de quem bebe o cálice e do qual as unhas devem ser cortadas. A tradução de Atena/Ediouro não o faz por duas vezes.

Tal omissão repetida é extremamente grave, pois a figura de São Bonaventura na polêmica sobre a pobreza dentro da Ordem Franciscana é de extrema importância. Boaventura era acusado, pelos spirituali, de excessiva tolerância com a comunidade propensa a

mitigações da pobreza.

- FXLIX

\begin{tabular}{|c|c|c|c|}
\hline Newton & Garzanti & Atena/Ediouro & Vozes \\
\hline "Ma imperò che Iddio & "Ma imperò che Iddio & Mas como Deus cuida & "Mas porque Deus tem \\
\hline ha singolare cura de' & ha singolar cura de' & singular & singular cuidado com \\
\hline suoi & suoi & filhos, & o-lhes, \\
\hline econdo i diversi & loro, secondo diversi & segundo os & conforme a \\
\hline tempi, $\quad$ ora & tempi, & tempos, & dos tempos, \\
\hline consolazione, & consolazione, & consolação, & consolação, \\
\hline tribolazione, & tribolazione, & tribulações, & tribulação, \\
\hline prosperità, & erità, & & \\
\hline $\begin{array}{l}\text { avversita, } S \\
\text { vede ch }\end{array}$ & ch’è bis & $\begin{array}{l}\text { em humildade para } \\
\text { mais acender o seu }\end{array}$ & $\begin{array}{l}\text { adversidade, } \\
\text { que as precis }\end{array}$ \\
\hline $\begin{array}{l}\text { loro a mantenersi in } \\
\text { umiltà, ovvero per }\end{array}$ & $\begin{array}{l}\text { per mantenergli in } \\
\text { umiltà, ovvero per }\end{array}$ & $\begin{array}{l}\text { desejo das coisas } \\
\text { celestiais..." }- \text { (p. } 188 \text { e }\end{array}$ & $\begin{array}{l}\text { se manterem na } \\
\text { humildade, ou para }\end{array}$ \\
\hline $\begin{array}{l}\text { accendere più il loro } \\
\text { desiderio alle cose } \\
\text { celestiali..." - (p. 84). }\end{array}$ & $\begin{array}{l}\text { accendere più il loro } \\
\text { desiderio alle cose } \\
\text { celestiali..." - (p. 149). }\end{array}$ & $\begin{array}{ll}\text { p. } & 125 \\
\text { respectivamente). } & \end{array}$ & $\begin{array}{l}\text { lhes acender o desejo } \\
\text { das coisas celestiais..." } \\
\text { - (p. 100). }\end{array}$ \\
\hline
\end{tabular}

Resumo de trecho em Atena/Ediouro.

\begin{tabular}{|c|c|c|c|}
\hline Newton & Garzanti & Atena/Ediouro & Vozes \\
\hline $\begin{array}{l}\text { “...alcuna volta agli } \\
\text { ardori de’ Serafini...” - } \\
\text { (p. 84). }\end{array}$ & $\begin{array}{l}\text { “...alcuna volta agli } \\
\text { ardori de' serafini..." } \\
\text { (p. 149). }\end{array}$ & $\begin{array}{l}\text { “... "algumas vêzes ao } \\
\text { ardor dos Serafins"..." } \\
\text { (p. } 188 \text { e p. } \mathbf{1 2 4} \\
\text { respectivamente). }\end{array}$ & $\begin{array}{l}\text { "... de outras vêzes a } \\
\text { ardores de serafins..." - } \\
(\mathbf{p . ~ 1 0 0 )} \text {. }\end{array}$ \\
\hline
\end{tabular}

A tradução de Atena/Ediouro acrescenta aspas inexistentes nos originais. 


\begin{tabular}{|c|c|c|c|}
\hline Newton & Garzanti & Adelino Capistrano & Durval de Morais \\
\hline $\begin{array}{l}\text { "Gesù gli stese e } \\
\text { porse..." - }(\mathbf{p . ~ 8 6}) .\end{array}$ & $\begin{array}{l}\text { "Gesù gli distese e } \\
\text { porse..." - (p. 152). }\end{array}$ & $\begin{array}{l}\text { "Jesus Cristo lhe } \\
\text { estendeu e ofereceu..." } \\
-(\text { p. } 191 \text { e p. } \mathbf{1 2 6} \\
\text { respectivamente). }\end{array}$ & $\begin{array}{l}\text { "Jesus Cristo lhe } \\
\text { estendeu e deu-lhe..." - } \\
\text { (p. 102). }\end{array}$ \\
\hline
\end{tabular}

Acréscimo em Vozes e em Atena/Ediouro. Possível variante da fonte consultada.

\begin{tabular}{|c|c|c|c|}
\hline Newton & Garzanti & Atena/Ediouro & Vozes \\
\hline $\begin{array}{l}\text { "...dichiarava le } \\
\text { sottilissime questioni ed } \\
\text { alte della Trinità..." - } \\
\text { (p. 86). }\end{array}$ & $\begin{array}{l}\text { “...dichiarava le } \\
\text { quistioni sottilissime e } \\
\text { alte della Trinità..." - } \\
\text { (p. 153). }\end{array}$ & $\begin{array}{l}\text { “...elucidava as } \\
\text { sutílissimas questões e } \\
\text { dúvidas sobre a } \\
\text { Trindade..." - (p. } \mathbf{1 9 2} \text { e } \\
\text { p. } \\
\text { respectivamente). }\end{array}$ & $\begin{array}{l}\text { “...resolvia e explicava } \\
\text { as subtilíssimas } \\
\text { questões da trindade } \\
\text { divina..." - }(\mathbf{p . ~ 1 0 3 ) .}\end{array}$ \\
\hline
\end{tabular}

Em Atena/Ediouro temos o acréscimo da palavra "dúvidas" e, nas três edições consultadas, a omissão do adjetivo alte.

\begin{tabular}{|c|c|c|c|}
\hline $\begin{array}{l}\text { Newton } \\
\text { "E durogli questa cotale } \\
\text { tribolazione per molti } \\
\text { dì, nelli quali egli } \\
\text { perseverò in continovo } \\
\text { piagnere e in sospirare e } \\
\text { in pregare Iddio che gli } \\
\text { rendesse per la sua pietà } \\
\text { il diletto isposo } \\
\text { dell' anima sua." - (p. } \\
\text { 85). }\end{array}$ & $\begin{array}{l}\text { Garzanti } \\
\text { "E durogli questa cotal } \\
\text { tribolazione per molti } \\
\text { dì; ne' quali egli } \\
\text { perseverò in continuo } \\
\text { piangere e sospirare, e } \\
\text { in pregare Iddio che gli } \\
\text { rendesse per sua pietà il } \\
\text { diletto } \\
\text { dell'anima sua." }-(\mathbf{p} . \\
\text { 150). }\end{array}$ & $\begin{array}{l}\text { Atena/Ediouro } \\
\text { "E prolongou-se esta } \\
\text { tribulação por muitos } \\
\text { dias; na qual ele } \\
\text { perseverou, chorando } \\
\text { continuamente, pela sua } \\
\text { piedade, o dileto esposo } \\
\text { da sua alma." - (p. 189 } \\
\text { e p. } \\
\text { respectivamente). }\end{array}$ & $\begin{array}{l}\text { Vozes } \\
\text { "E durou-lhe esta } \\
\text { atribulação por muitos } \\
\text { dias, durante os quais } \\
\text { perseverou em conítnuo } \\
\text { chorar e suspirar, } \\
\text { pedindo a Deus que lhe } \\
\text { restituísse por sua } \\
\text { piedade o dileto espôso } \\
\text { de sua alma." - (p. } \\
\text { 101). }\end{array}$ \\
\hline
\end{tabular}

Resumo de trecho em Atena/Ediouro.

- $\quad F$ LIII

\begin{tabular}{|c|c|c|c|}
\hline Newton & Garzanti & Atena/Ediouro & Vozes \\
\hline $\begin{array}{l}\text { "...addivenne una volta } \\
\text { questo mirabile caso, } \\
\text { che la prima notte dopo }\end{array}$ & $\begin{array}{l}\text { "...addivenne una volta } \\
\text { questo mirabile caso: } \\
\text { che la prima notte dopo }\end{array}$ & $\begin{array}{l}\text { "...aconteceu uma vez } \\
\text { êste admirável caso: } \\
\text { que a primeira noite }\end{array}$ & $\begin{array}{l}\text { "...sucedeu uma vez } \\
\text { este caso admirável, } \\
\text { que na primeira noite }\end{array}$ \\
\hline l'ottava di santo & l'ottava di santo & após a oitava de S. & depois da oitava de $\mathrm{S}$. \\
\hline $\begin{array}{l}\text { Lorenzo e infra l'ottava } \\
\text { dell'Assunzione della }\end{array}$ & $\begin{array}{l}\text { Lorenzo e infra l'ottava } \\
\text { della Assunzione della }\end{array}$ & $\begin{array}{l}\text { Lourenço, e entre a } \\
\text { oitava da Assunção de }\end{array}$ & $\begin{array}{l}\text { Lourenço e dentro da } \\
\text { Assunção de Nossa }\end{array}$ \\
\hline
\end{tabular}




\begin{tabular}{|l|l|l|l|}
\hline Donna..." - (p. 89). & $\begin{array}{l}\text { Donna..." - (pp. 158- } \\
\text { 159). }\end{array}$ & $\begin{array}{l}\text { nossa Senhora..." - (p. } \\
\mathbf{2 0 1} \text { e penhora..." - (p. 106). } \\
\text { respectivamente). }\end{array}$ & 132 \\
\hline
\end{tabular}

Omissão em Vozes.

- $\quad F$ LIII

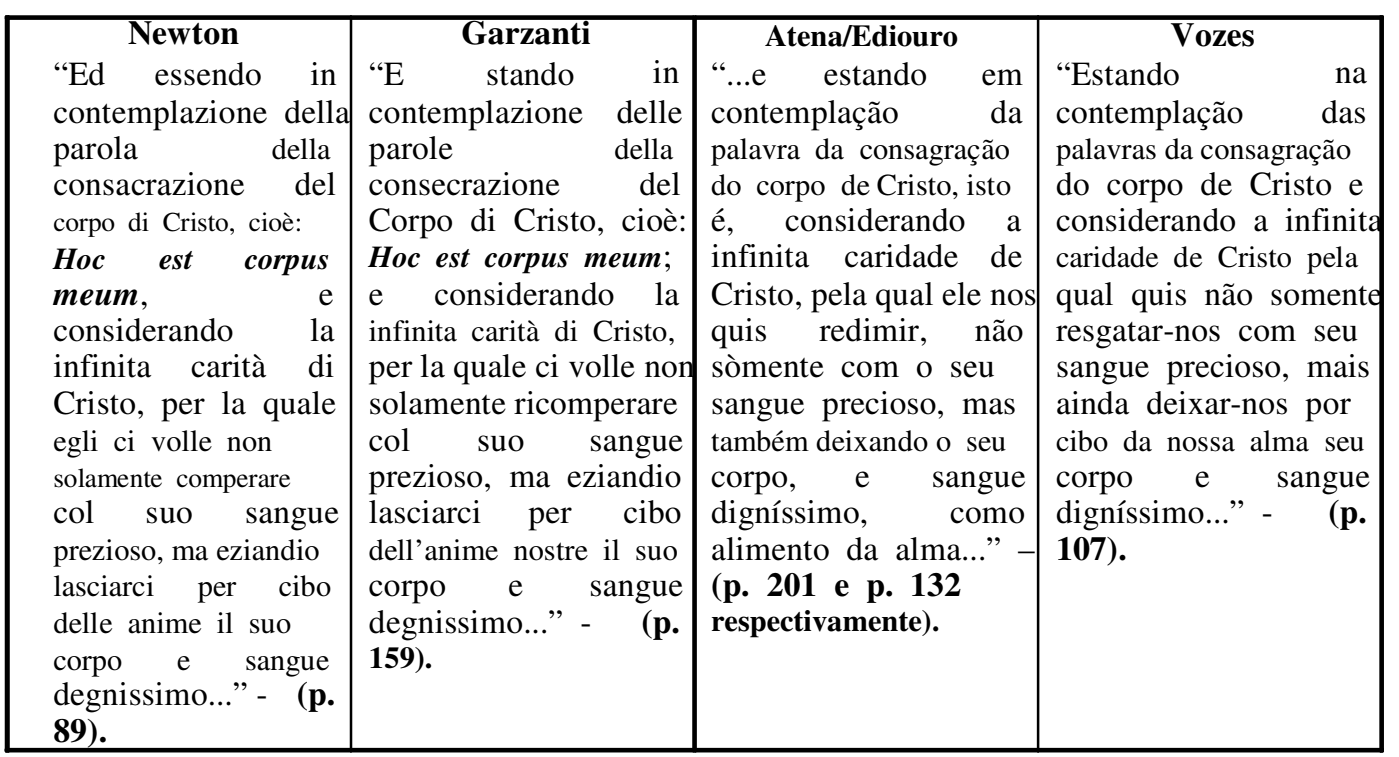

Omissão em ambas as traduções brasileiras de trecho em latim.

- $\quad$ FLIII

\begin{tabular}{|c|c|c|c|}
\hline $\begin{array}{l}\text { Newton } \\
\text { «...ne fu portato in } \\
\text { sagrestia come morto, } \\
\text { imperò che il corpo suo } \\
\text { era raffreddato come } \\
\text { corpo morto..." - (p. } \\
\text { 90). }\end{array}$ & $\begin{array}{l}\text { Garzanti } \\
\text { “...egli ne fu portato in } \\
\text { sagrestia come morto, } \\
\text { imperò che "l corpo suo } \\
\text { era raffreddato come } \\
\text { corpo } \quad \text { d'uomo } \\
\text { morto..." - (p. 161). }\end{array}$ & \begin{tabular}{l}
\multicolumn{1}{c}{ Atena/Ediouro } \\
“...êle foi transportado à \\
sacristia como morto, \\
pois o seu corpo se \\
esfriara...” - (p. 203 e \\
p.133 \\
respectivamente).
\end{tabular} & $\begin{array}{l}\text { Vozes } \\
\text { “...êle foi levado para a } \\
\text { sacristia como morto, } \\
\text { porque seu corpo estava } \\
\text { frio como o corpo de } \\
\text { um morto..." - (p. } \\
\text { 108). }\end{array}$ \\
\hline
\end{tabular}

Em Atena/Ediouro temos a omissão da comparação "raffreddato come corpo morto". 


\begin{tabular}{|c|c|c|c|}
\hline Newton & Garzanti & Atena/Ediouro & Vozes \\
\hline $\begin{array}{l}\text { “...anco gli era da Dio } \\
\text { istato rivelato che in } \\
\text { quel caso gli avea a } \\
\text { divenire intorno alla } \\
\text { detta festa } \\
\text { dell'Assunzione; ma } \\
\text { poi non se ne ricordava } \\
\text { della detta rivelazione." } \\
\text { - (p. 91). }\end{array}$ & $\begin{array}{l}\text { "...anche gli era stato } \\
\text { revelato da Dio che } \\
\text { quello caso gli dovea } \\
\text { addivenire intorno alla } \\
\text { detta festa della } \\
\text { Assunzione; ma poi non } \\
\text { se ne ricordava della } \\
\text { detta rivelazione." - (p. } \\
\mathbf{1 6 2}) \text {. }\end{array}$ & $\begin{array}{l}\text { “...ainda lhe fôra } \\
\text { revelado por Deus que } \\
\text { aquêle caso lhe devia } \\
\text { acontecer por ocasião } \\
\text { da dita festa da } \\
\text { Assunção; mas depois } \\
\text { não se recordava da } \\
\text { dita visão, ou } \\
\text { revelação que lhe } \\
\text { fizera nosso Senhor." } \\
\text { - (p. 204 e p. } 134 \\
\text { respectivamente). }\end{array}$ & $\begin{array}{l}\text { "...ainda lhe fora por } \\
\text { Deus revelado que } \\
\text { aquele caso lhe devia } \\
\text { advir por volta da dita } \\
\text { festa da Assunção; mas } \\
\text { depois não se recordou } \\
\text { da dita revelação." - (p. } \\
\text { 108). }\end{array}$ \\
\hline
\end{tabular}

Acréscimo em Atena/Ediouro. 


\section{Considerações Finais}

Como vimos, a obra I Fioretti di San Francesco é representada no Brasil através de traduções feitas já há algum tempo. Edições esgotadas. Quem lê I Fioretti em português brasileiro os buscou/encontrou em uma biblioteca ou sebo.

Tendo então o “corpus” restrito às duas traduções já citadas - no cotejo com o original proposto por mim como análise - redigi algumas constatações a respeito das "leituras" dadas pelos tradutores.

Retomo aqui o conceito de tradução por mim adotado desde o início: a tradução como um ato lingüístico metonímico.

Como já dito no Capítulo 1, todo ato lingüístico pode ser considerado metonímico, já que a língua comporta a 'transformação' de vivências particulares de mundo em algo convencionalizado e comum a um grupo. Nesta 'transformação' apenas parte da vivência particular é transmitida.

Há diversos graus de 'transformação': do mais 'leve' (duas pessoas que falam a mesma língua, vivem na mesma casa e falam ‘janela') ao mais 'drástico' (pessoas que falam línguas diferentes, vivem em continentes diferentes e falam sobre um poema).

Procurei lidar aqui com os graus mais 'drásticos' - tradução interlingüística (ainda que entre duas línguas latinas) de uma obra literária.

Assim acontece com IF quando dois tradutores diferentes se propõem a reescrever a obra em português. Uma obra italiana transformou-se em duas traduções brasileiras que, apesar de essencialmente semelhantes, trazem soluções bem diversas que pressupõem e produzem leituras diferentes da mesma obra.

Podemos notar parte da diversidade de tais soluções através das escolhas lexicais adotadas pelos tradutores dos mesmos vocábulos italianos. Vale concluir alguns exemplos já comentados.

Morais traz "frei" e Capistrano "irmão". Ambas as escolhas tradutórias se referem ao vocábulo "frate" como já vimos (cf. pp. 40-41). O primeiro leu e fez ler - considerando o tradutor um leitor da obra que traduz - o original de maneira mais clericalizada, dentro de um contexto mais formal: uma leitura possível de $I F$, mas que pareceu tornar-se única quando levamos em consideração a introdução que precede as escolhas do tradutor (cf. Capítulo 2 -

2.2). Não foi esta a única escolha clerical de Morais - cito outras: "sóror" (p. 42); "monsior" 
(pp. 43-44); "em verdade" (pp. 56-57); "meu venerando padre” (p. 73); a tradução de "luogo" por “convento" (pp. 92-93).

Capistrano traz uma leitura, em geral, menos clericalizada em suas opções para os vocábulos italianos "frate", "suora", "messer", "padre" - "irmão", "irmã" (exceto no $F$ XXXIII em que traz como solução "sóror" assim como Durval de Morais), "senhor", "pai" (cf. pp. 40-41; 42; 43-44 e 73 respectivamente).

Quando nos deparamos com esta "clericalização", é interessante lembrar a questão franciscana entre conventuali e spirituali; e reafirmar que, para os estudiosos IF é tomado como um texto de origem spirituale (cf. Capítulo 1 - 1.3). Sublinho ainda o fato de Durval de Morais ser franciscano observante, ou seja, moderado em relação aos antigos spirituali. A Editora Vozes é também propriedade dos franciscanos observantes.

Seguindo a análise constata-se a maior formalidade da tradução Vozes. O tradutor opta - várias vezes - por vocábulos que exigem do leitor um bom conhecimento do português e de sua origem latina. Trago como exemplos: "cibo" (pp. 42-43); "côdeas" (pp. 45-46); "enleio" (pp. 65-66); “citadino” (p. 66); “assaz” (p. 76); “mundícia” (p. 78); “letícia” (p. 79).

As editoras Atena e Ediouro trazem uma tradução que opta, neste sentido, por léxico mais simples, acessível ao leitor menos culto. Exemplos: "alimento" (pp. 42-43); "bocado" (pp. 45-46); “doçura” (pp. 65-66); “cidadão” (p. 66); “bastante” (p. 76); “limpeza” (p. 78); “alegria" (p. 79).

É importante mencionar que os termos que deram origem a traduções tão díspares em relação ao rebuscamento, são vocábulos de acesso fácil ao leitor de língua italiana: “cibo", "bocconi"; "dolcezza"; "cittadino"; "assai"; "mondizia"; "letizia".

A relativa simplicidade de Capistrano, muitas vezes, chega a contradizer a introdução dada por Giulio David Leoni (cf. Capítulo 2) à sua tradução. "O sabor das coisas antigas" muitas vezes é comprometido por esta modernização lingüística do texto. Cito aqui: “condutor" (p. 51); “instrumento de penitência" (pp. 77-78); a questão do verbo italiano "piacesse" (cf. pp. 80-81); a questão das horas canônicas (cf. pp. 28 e 51).

O que parece ainda mais estranho é que a tradução dada pelas editoras Atena e Ediouro traz, eventualmente, opções tradutórias bem arcaizantes dentro desta tradução simples. É o caso de "nojo" como tradução de "noia” (p. 64).

Outro ponto importante que demonstra leituras de caráter diferente dá-se pela tradução dos diminutivos - estes de extrema importância dentro do contexto da obra $I F$ como já foi anteriormente mencionado. 
Nem todos os diminutivos são preservados em ambas as traduções. Cito aqui um exemplo delicado: "sirocchie" (p. 49). Porém, quanto a esta questão, Morais demonstra maior cuidado na tradução (cf. diminutivos, pp. 32- 40); ainda que não totalmente atento (cf. pp. 5253 - "celluzza”). Capistrano demonstra menor cuidado quanto aos diminutivos (cf. páginas citadas neste mesmo parágrafo) e, por vezes, não apenas não os traduz, mas chega a transformar um deles em aumentativo pejorativo (vide "vil pobretão", p. 35).

Tal falta de atenção por parte de Capistrano diz bastante sobre a leitura apresentada em sua tradução - não houve um cuidado especial com a forma. Não só com a questão dos diminutivos, mas também através da não preservação da saudação final (cf. Capítulo 3 -3.1). Sem este cuidado com a forma, há uma perda significativa para a leitura literária da obra. Durval de Morais também faz perder bastante desta leitura literária (cf. "sirocchie mie uccelli”, p. 49; “celluzza”, pp. 52-53; "stropiccío", pp. 58-59; "usare/figliare”, p. 68; “caco", p. 72). Mas, por estar mais atento aos diminutivos, a alguns vocábulos bem específicos (cf. “gonfaloniere”, p. 51; “tetti”, pp. 57-58) e à preservação da saudação final (cf. Capítulo 3 3.1), parece estar mais atento à forma da obra e, por consequiência, à leitura literária da mesma. Não esqueçamos que Morais é poeta.

Dentro do ponto "Dar com esta mão e tirar com a outra..." (cf. p. 99), há algumas questões a serem consideradas. Constatamos uma insistência da tradução Atena/Ediouro em omitir e resumir trechos. Por duas vezes tal insistência ocasiona problema: a omissão da palavra "frate" em referência ao lobo de Gúbio (p. 101); a omissão do nome de Bonaventura (pp. 106-107).

Assim, temos uma tradução que, apesar de mais rebuscada e clericalizada, está mais atenta ao original como obra de valor literário; e uma que, apesar de menos atenta ao caráter literário da obra, é mais simples, mais acessível a todos em sua leitura.

Enfim, nenhuma das duas parece satisfatória; espero que este trabalho aponte questões importantes dentro das traduções brasileiras e traga subsídios para uma leitura, e talvez futura tradução de $I F$ no Brasil. 
Referências Bibliográficas

- Edições e traduções de I Fioretti:

I Fioretti di San Francesco. Garzanti: Milano, 2003.

I Fioretti di San Francesco. Tascabili Newton: Milano, 1993.

I Fioretti de São Francisco. Trad. Adelino Capistrano. Rio de Janeiro: Athena Editora, 1937.

I Fioretti de São Francisco. Trad. Adelino Capistrano. São Paulo: Atena Editora, sem data.

I Fioretti de São Francisco. Trad. Adelino Capistrano. Rio de Janeiro: Ediouro, sem data.

I Fioretti de São Francisco. Trad. Durval de Morais. Petrópolis: Vozes, 1964. $4^{\mathrm{a}}$ edição.

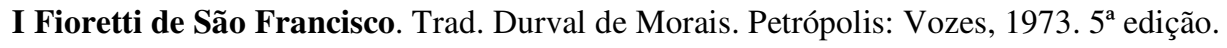

- Estudos sobre I Fioretti e cultura italiana medieval:

BALDASSARI, G. Letteratura devota, edificante e morale. IN: MALATO, Enrico (ed). Storia della Letteratura Italiana. Roma: Salerno, 2001. Volume II - Il Trecento. Capítulo $\mathrm{V}$.

CARDINI, F. Francesco d'Assisi. Milano: Mondadori, 1994.

FLORA, F. Arte religiosa. IN: Storia della Letteratura Italiana, I, Dal Medioevo alla fine del Quattrocento. Verona, 1946: p. 339. Extraído da Introdução de Pier Massimo Forni para I Fioretti di San Francesco. Milano: Garzanti, 2003.

FORNI, P M. Introduzione a I Fioretti di San Francesco. IN: I Fioretti di San Francesco. Milano: Garzanti, 2003. 
GHIRARDI, P G. São Franisco de Assis e o 'Cântico das Criaturas'. Videtur (USP), 2002. Volume 5, pp. 15-20.

GUALDO, R.; PALERMO, M. La prosa del Trecento. IN: MALATO, Enrico (ed). Storia della Letteratura Italiana. . Roma: Salerno, 2001. Volume X - La tradizione dei testi, Capítulo VIII.

PETROCCHI, G. Dagli 'Actus Beati Francisci' al volgarizzamento dei Fioretti. IN: Ascesi e Mistica trecentesca. Firenze: Felice Le Monnier, 1957.

SALINARI, C; RICCI, C. Storia della Letteratura Italiana: con Antologia degli Scrittori e dei Critici. Roma: Laterza, sem data. Volume 1 - Dalle origini al Quattrocento.

SALVATORELLI, L. Sommario della Storia d'Italia - dai tempi preistorici ai nostri giorni. $2^{\mathrm{a}}$ edição. Torino: Giulio Einaudi Editore, 1982.

Storia d'Italia. Torino: Giulio Einaudi Editore, 1974. Vol. II: "Dalla caduta dell'Impero romano al secolo XVIII".

TUSCANO, P. Rassegna di testi e studi francescani (1965-1975). IN: Lettere Italiane (diretta da Vittore Branca e Giovanni Getto). Firenze: Leo S. Olschki Editore. Rivista Trimestrale - ano XXVIII - no 3 - Julho-Setembro, 1976.

- Estudos sobre tradução:

AUBERT, F. H. As (in)fidelidades da tradução: servidões e autonomia do tradutor. Campinas: Editora da UNICAMP, 1992.

BADER, Wolfgang (Org). Brecht no Brasil - Experiências e Influências. Rio de Janeiro: Editora Paz e Terra, 1987.

BARBOSA, Onédia Célia de Carvalho. Byron no Brasil: traduções. São Paulo: Ática, 1974.

BASNETT, S. Translation Studies. London: Routledge, 2002.

BORGES, J. L. Las dos maneras de traducir. IN: Textos Recobrados 1919-1929. Buenos Aires: Emecé, 1997. 
EAGLETON, Terry. A política da amnésia. IN: Depois da Teoria - Um olhar sobre os estudos culturais e o pós-modernismo. Trad: Maria Lúcia Oliveira. Rio de Janeiro: Civilização Brasileira, 2005.

ECO, U. Dire quase la stessa cosa. Milano: Bompiani, 2003.

FARIA, Gentil Luiz de. A Recepção e a Influência de Oscar Wilde na "Belle Époque" Literária Brasileira: Contribuição aos Estudos de Literatura Comparada no Brasil. Tese de Doutorado: FFLCH-USP, São Paulo, 1979.

FOUCAULT, Michel. What's an author?. IN: HARARI, Josué (org). Textual Strategies perspectives in post-structuralist criticism. England: Methuen, 1979.

GENETTE, G. Paratexts - Thresholds of Interpretation. Trad. Jane E. Lewin. Cambridge:

Cambridge University Press, 1997.

MILTON, J. Tradução: Teoria e Prática. São Paulo: Martins Fontes, 1998.

STEINER, G. After Babel - Aspects of language \& translation. Oxford, New York: Oxford University Press, 1992.

TYMOCZKO, M. The Metonymics of Translation. IN : Translation in a Postcolonial

Context - Early Irish Literatura in English Translation. Manchester: St. Jerome Publishing, 1999. p. 42.

VENUTI, L. Direitos Autorais. IN: Escândalos da Tradução - por uma ética da diferença. Trad. Laureano Pelegrin et al. Bauru: EDUSC, 2002.

- Obras diversas:

Dicionário Aurélio da Língua Portuguesa. Rio de Janeiro: Nova Fronteira, sem data.

Dicionário de Latim-Português. Porto: Porto Editora, 2001. $2^{\text {a }}$ edição. 
ECO, U. Lector in fabula: a cooperação interpretativa nos textos narrativos. São Paulo: Perspectiva, 1986.

Enciclopedia Cattolica. Firenze: Casa Editrice G.C. Sansoni, 1953. Vol. V.

Enciclopedia Italiana di Scienze, Lettere ed Arti. Roma: Istituto della Enciclopedia Italiana, 1949. vol. XV.

Lo Zingarelli 2005: Vocabolario della Lingua Italiana. Bologna: Zanichelli, 2005.

NITRINI, S. Literatura Comparada: história, teoria e crítica. $2^{\mathrm{a}}$ edição, São Paulo: Editora da Universidade de São Paulo, 2000. 
This document was created with Win2PDF available at http://www.win2pdf.com.

The unregistered version of Win2PDF is for evaluation or non-commercial use only. This page will not be added after purchasing Win2PDF. 